\title{
Graffiti en la muralla del Albayzín
}

\author{
José Ignacio Barrera Maturana *
}

\begin{abstract}
RESUMEN
En estas páginas tratamos de dar a conocer un conjunto muy variado de graffiti medievales (cruces, castillos, inscripciones, barcos...) descubiertos en la Muralla nazarí del barrio del Albayzín de Granada (España), y que desde finales del siglo XIX, sólo conocíamos a través de unas pocas páginas insertas en guías locales y breves artículos posteriores. Nuestro trabajo ha consistido en rescatados del olvido, intentar comprender lo que en sí representan estas manifestaciones de carácter popular y valorar la información que estos nos pueden aportar sobre diversos aspectos de la Historia Medieval de nuestra ciudad.
\end{abstract}

PALABRAS CLAVE: Graffiti, muralla, Albayzín, nazarí, castillos, cruces.

El trabajo que estamos desarrollando sobre los graffiti medievales existentes en la muralla nazarí que rodea el barrio del Albayzín de Granada, popular y erróneamente denominada Cerca de Don Gonzalo, por creerse que los gastos que ocasionó la construcción de la misma fueron sufragados con el importe del rescate del Obispo de Jaén don Gonzalo de Zúñiga ( | 423-1456), supuesto cautivo en manos de los granadinos (VILLA-REAL, I888: 309-3I I), se enmarca dentro de un programa más amplio de actuación sobre este tipo de representaciones, que abarca distintas zonas de nuestra geografía andaluza, principalmente las provincias de Almería y Granada (BARRERA, en prensa; BARRERA y CRES-

\begin{abstract}
This articles seeks to make known to a collection of very varied medieval graffiti (crosses, castles, inscriptions, boats...) discovered on the nazari wall in the Albayzín quarter of Granada (Spain), and which, since the end of the 19 th. Century, has only been referred to through a few pages inserted in local guides and short articles. Our work has consisted in saving this graffiti from oblivion, in trying to understand what these popular sign represents and in evaluating the information that these can provide about the different aspects of the Medieval times in our city.
\end{abstract}

KEY WORDS: Graffiti, wall, Albayzín, nazari, castles, crosses.

SIER, en prensa; CRESSIER, 1986a; CRESSIER et alii.. 1992; CRESSIER et alii., I99 I).

Nuestro interés por los graffiti existentes en la muralla granadina, ha sido motivado, por una parte, por la situación de abandono y olvido en que se encontraban desde que en I 886 y 1887 fueron visitados por la Sección de Excursiones del Centro Artístico de Granada, llevándose a cabo varios facsímiles de lo encontrado, así como fotografías y vaciados en yeso, todo ello dirigido por Manuel Gómez Moreno, desconociéndose actualmente el paradero de estos trabajos (MARTíN, 1985-87: 180); y por otra parte, por lo que en sí representan, dado

* Arqueólogo. 
el escaso interés que se ha mostrado en nuestra capital, por el estudio de estas manifestaciones, conociéndose sólo algunas referencias, como por ejemplo de los localizados en las excavaciones del Maristán de Granada (GARCÍA, GIRON y SALVATIERRA, 1989: 49-50; GARCIA y SALVATIERRA, 1981:22), en la Casa de Zafra (MEDINA y MANZANO, 1995: 54-56 y Im. I 4;ALMAGRO y ORIHUELA, 1997), de los existentes en la cúpula de la Puerta de las Armas de la Alhambra (RODRIGO y CALANCHA, 1990: Ims.30-3 I ), o de los hallados en una casa morisca del Albayzín (DE SANTIAGO, 1974).

Pero a pesar de los inconvenientes mostrados, y gracias a la situación espacial algo marginal que ocupa la muralla respecto al entramado urbano de la ciudad (en terrenos escasamente o no urbanizables), frenando de este modo la acción destructiva del hombre actual, hemos podido recuperar un considerable número de motivos, de todos los que en su día Gómez Moreno pudo contemplar en mejor estado (GOMEZ, I892: 491-493).

Consideramos de gran importancia el conjunto que aquí presentamos, ya que hasta la actualidad nuestro campo de trabajo se ha limitado al estudio de este tipo de representaciones existentes sobre rocas en parajes naturales y en construcciones de época islámica (aljibes de castillos, murallas,...), todos ellos situados en medios rurales y nunca en edificios medievales integrados en un núcleo urbano, a excepción de los que hemos localizado en la red de alcantarillado de Madinat al-Zahra (BARRERA, CRESSIER y MOLINA, 1999; VV.AA., 1991: 16), así como otros encontrados en los edificios de este conjunto arqueológico, actualmente en fase de estudio. De esta manera podemos establecer paralelismos no sólo en la región sino con otros puntos de la Península, ampliando el corpus de motivos conocidos hasta ahora en nuestra zona de estudio. Igualmente hemos de considerar de bastante relevancia el conocer a través de las fuentes escritas, la fecha aproximada de la construcción de la muralla, frente al resto de la inmensa mayoría de los edificios medievales que soportan graffiti, estudiados por nosotros.

\section{LA MURALLA: DESCRIPCIÓN Y CRONOLOGÍA}

La muralla nazarí de Granada cercaba exteriormente el Rabad al-Bayyazin o arrabal del Albayzín, como se le denominó desde finales del siglo XIV, situado junto a la antigua Alcazaba Qadima.

Partía de Este a Oeste en la confluencia del actual Paseo de los Tristes con la Cuesta del Chapiz, después subía en dirección Norte hasta la Ermita de San Miguel, continuaba hacia el Oeste, hasta la llamada "Curva del Tambor" en la carretera Nacional Granada-Murcia, donde se desviaba en dirección Sur hasta enlazar con la Puerta de Elvira. Este recorrido está interrumpido actualmente por quince torres, así como por dos de las seis puertas que daban acceso al barrio: la Puerta de Fajalauza y la Puerta de San Lorenzo o del Albayzín. Por tanto la muralla tenía una longitud aproximada de $2.300 \mathrm{~m}$., de los que se conservan en la actualidad I.475 m., pudiéndose calcular un volumen aproximado de tapial utilizado en la construcción de ésta de $16.000 \mathrm{~m}^{3}$. También podemos observar una mayor dureza y una mejor calidad de la argamasa en el tramo final, a partir de la mencionada Puerta de Fajalauza, conservándose restos del parapeto superior que coronaba la muralla (MARTíN, 1985-87: 180).

Respecto a la fecha de construcción de la muralla aceptamos la propuesta por Luis Seco de Lucena, quien tras rechazar una serie de tradiciones sin base documental fiable, que fechaban la construcción de ésta en el siglo $X V$, nos dice que en la "Cuarta Crónica General", en I28 I, cuando Alfonso X entró en la Vega de Granada, aún no había sido construida (la muraIla), estándolo ya cuando se escribió la continuación de la "Crónica de España" del Arzobispo Don Rodrigo Jiménez de Rada, donde aparece lo siguiente: "... una cabeça que decían Aviezin la cual agora han metido en la cerca del muro de la villa, que entonces non era asî.

Pero es Ibn al-Jathib, en su Ihata, donde inserta una biografía de Abu-I-Nu caym Ridwan, que ocupó el cargo de hachib (1329-1359), durante los reinados de Muhammad IV, Yusuf 
I y Muhammad $\mathrm{V}$, quien nos relata que fue Yusuf I el que mandó construir la muralla del Albayzín, a instancias de su ministro Ridwan. Podemos centrar la construcción de ésta, durante el reinado de Yusuf I (I333-1354) y más concretamente entre los años 1338 (ya que en 1337 al-Umari visitó Granada, dejándonos una de las descripciones más completas que existen de la ciudad en el siglo XIV, y en ningún momento cita la muralla), y I359, fecha en que murió asesinado Ridwan (SECO DE LUCENA, 1965; MARTÍN, 1985-87;VILCHEZ, 1988).

A nivel arqueológico, se llevaron a cabo en el tramo final de la muralla ocho catas de los cimientos de ésta, con la localización de los niveles medievales, así como la excavación completa de la Puerta de San Lorenzo, pudiéndose comprobar que la construcción de esta puerta y de la torre que existe junto a ella, fueron posteriores al trazado de la muralla, posiblemente adosadas a finales del siglo XIV o ya en el siglo $\mathrm{XV}$, según se desprende de las características de la puerta y del material cerámico encontrado (VILCHEZ, 1988;VILCHEZ, 1990).

\section{MÉTODO DE ESTUDIO Y ESTADO DE CONSERVACIÓN DE LOS GRAFFITI}

Gracias a los trabajos que desde hace unos años se están desarrollando sobre este tipo de representaciones de carácter popular, que conviven con el arte y la cultura "oficial" de una época, se ha comprobado la importancia y la valiosa información que estos pueden aportar acerca de las costumbres, la vida cotidiana y la religiosidad de una sociedad.

Así pues, el graffiti como tal, ha pasado de ser considerado una manifestación marginal, sin intencionalidad alguna de transmitir un mensaje o idea concreta, a ser un elemento importante en la comprensión de algunos aspectos de la Historia Medieval.
En torno a esta idea se desarrolla nuestra línea de trabajo sobre este tipo de grabados, acercándonos a ellos mediante el directo trabajo de campo, así como a través de las fuentes escritas, encontrando en estas últimas algunas referencias sobre los mismos, como por ejemplo las que nos ofrece Luis del Mármol Carvajal en el siglo XVI, sobre otros existentes en el recinto más antiguo de la Alcazaba Qadima: "También nos mostró un morisco unas letras árabes, escritas en una tapia deste propio muro antiguo que parecía haber sido hechas con algún hierro o palo delgado, estando la argamasa blanda, al tiempo que tapiaban, en los cuales se contienen palabras del Alcorán, que es testimonio de haberse hecho en tiempos de alárabes setarios, y no antes" '; o el sugestivo y breve texto que acompaña a tres dibujos de Hoefnagel, que reproducen vistas de Granada, insertos en la obra Civitates Orbis Terrarum, fechados respectivamente, en 1563 , I 564 y I 565, observándose en el lugar correspondiente a la Silla del Moro, una torre sobre una plataforma y algunos lienzos de muros ruinosos inmediatos, llevando el letrero de Santa Elena. El aludido texto nos informa de la existencia en el cerro de Santa Elena de un templo de moros, consagrado entonces a esa santa, al que subían para escribir en sus paredes su nombre y cuna los visitantes de Granada (TORRES, 1948a).

Si consideramos esta información como veraz, estaríamos ante la posible existencia en este cerro de una mezquita, rábita o zawiya (TORRES, 1948b; PAVON, 1996: 20I-212), a la que acudirían los extranjeros, y quizás los mismos granadinos, a venerar y honrar, como lugar de devoción y piedad, dejando grabados en los muros sus nombres y lugares de origen, tal como ha quedado constatado arqueológicamente a través de los graffiti encontrados en la Rábita califal de las dunas de Guardamar en Alicante (AZUAR, 1989). También nos habla Abu I-Barakat al-Balafiqi, en su repuesta a los juristas malikíes, apropósito de una ermita construida para extranjeros en la que se daban cita los

I En el Libro Primero, Capítulo V, página 36. 
sufíes, que en España y Marruecos, había la costumbre de mostrarse indulgentes con las desviaciones de los faquires debido a la hos-. pitalidad que se daba a los viajeros en las zawiyas, donde estos hallaban refugio y ayuda (ARTE, 1984: 355-356; ANGELE y CRESSIER, 1992: 247-248 y 259). Este fenómeno podría dar respuesta en parte, a una posible inscripción árabe existente en la cara exterior del muro sureste de la Rábita de Dalías, y que Patrice Cressier propone la posibilidad de que fuese realizada durante la rebelión de los moriscos y por tanto ligeramente anterior a otros graffiti cristianos que hay junto a ella (CRESSIER, 1986a; RODRÍGUEZ y CARA, 1990).

Retomando el tema de nuestros graffiti, y en concreto a lo referente a su conservación, hemos de decir que se encuentran en muy mal estado, debido, por una parte, a los efectos de los diversos agentes atmosféricos, que han producido la aparición de grandes socavones, así como el desprendimiento del enlucido exterior ${ }^{2}$ de la muralla, principal soporté de estos; y por otra parte, debido a la serie de inadecuadas restauraciones y consolidaciones que ha sufrido la muralla desde la década de los sesenta hasta nuestros días, mediante la utilización para ello, de mampostería y más abundantemente de ladrillo macizo visto. Estos dos hechos han afectado principalmente a las zonas más bajas, incidiendo directamente en el continuo deterioro de los graffiti, ya que se sitúan aproximadamente a una altura máxima de dos metros desde el actual nivel del suelo, dando lugar a la desaparición total o parcial de estos grabados, siendo en la actualidad ilegibles muchos de ellos.

A pesar de estas dificultades, nuestro primer acercamiento al conjunto nos ha permitido distinguir dos técnicas diferentes en el proceso de elaboración de los graffiti: motivos picados directamente sobre el tapial, y motivos incisos sobre el enlucido aún fresco que cubre las estructuras murarias.

La metodología utilizada para la reproducción de estos, difiere según la técnica en que se realizaron. Así pues, los motivos picados han sido reproducidos a partir de fotografías realizadas perpendicularmente a la pared donde se encuentran; en cambio, hemos procedido al levantamiento, mediante calcos sobre película plástica transparente de los motivos incisos. Tanto los trazos de unos como los de los otros, han sido precisados con la ayuda de fotografías de detalle y con sucesivas visitas al conjunto.

Los graffrti aparecen distribuidos a lo largo del trazado de la muralla: en los lienzos y torres de ésta e incluso en el interior de la Puerta de Fajalauza. Pero es en la cara exterior donde se concentra el mayor número de graffiti y más abundantemente en el Sector A, que se extiende desde la Vereda de Enmedio Afta, en el Sacromonte, hasta la Ermita de San Miguel (Fig. I).

Antes de entrar de lleno a estudiar los distintos motivos localizados en la muralla, merece reproducir algunos fragmentos del texto de Gómez Moreno, inserto en su Guía de Granada, donde nos describe los graffiti que pudo contemplar:

"También esclarecen esta cuestión, gran número de figuras é inscripciones de singular importancia, grabadas sobre el enlucido exterior de la muralla, estando recién hecha..."

"Las inscripciones están escritas en castellano, más desgraciadamente son en gran parte ilegibles..."

"Entre estos letreros y los demás enteramente ilegibles ó borrados á poco de escritos, hemos visto letras árabes bien trazadas, algunas de las cuales al parecer forman la palabra bismi (en el nombre), y además grandísimo número de figuras toscamente y sin arte delineadas á lo largo del muro: ya son embarcaciones de muy diversas formas, que es lo más repetido; ya un caballero cristiano con capacete/bacinete, lanza y triangular escudo; ya caballos enjaezados y corriendo; ya mujeres moras con bordados vestidos, una de las cuales distínguese detrás de

2 A veces no existe enlucido como tal, sino que se trata de la capa de cal que se forma por capilaridad al secarse el conjunto. 
una mesa, al parecer; ya una mano como la de la puerta Judiciaria; ya ciervos, pájaros, peces, perros y otros animales; ya castillos y un puente fortificado, con torres y banderas, bajo del cual pasa un barco; ya finalmente cierto escudo triangular con castillos dentro y en su parte superior, estrellas de Salomón, príapos/phalos y otras figuras de explicación más dificil.

En la vertiente occidental del monte hay en la muralla trazado por distinta mano, seguramente mora, un pavo real, y más abajo de la puerta de Fajalauza, un arquito de herradura con sus dovelas y recuadro, todo ello hecho por la parte de afuera con una punta sobre el revestimiento aún tierno de la muralla".

\section{LOS GRAFFITI}

\section{Motivos Picados}

\section{Motivos cruciformes}

La cruz es uno de los grabados que más aparece en la muralla granadina. La técnica de elaboración utilizada ha sido el picado del tapial. Generalmente suelen ser cruces latinas simples, latinas que nacen de una peana triangular o del vértice de un ángulo. Existen igualmente cruces potenzadas, patriarcal/papal y de Lorena.

Creemos que este tipo de graffiti es bastante posterior a la fecha de la construcción de la muralla, porque como hemos podido comprobar, se superponen a otros incisos en el enlucido aún fresco; y porque encontramos paralelismos entre estos y los documentados en numerosos yacimientos estudiados en las provincias de Almería y Granada, principalmente situados en las paredes internas de aljibes islámicos, realizados en un momento en el que estos estaban abandonados o dejaron de utilizarse para la función que en su día se construyeron, y que posiblemente fueron realizados durante la rebelión morisca o principios de la repoblación (CRESSIER, 1986a).
Paralelos de cruces latinas simples como las de la muralla (Figs.2 a 9 /Láms. I y IV), las encontramos en casi todos los yacimientos existentes en nuestra zona de estudio, teniendo como principal ejemplo los localizados en las paredes de uno de los aljibes del Castillo de Juviles (Alpujarra de Granada), denominado Ermita de los Moros, repletas de estas cruces.

Las cruz latina que nace de una peana triangular (tal vez simulando la cruz de calvario) (Figs. I0, I I y |7), la encontramos casi exclusivamente en las paredes internas del aljibe del Castillo de Albox (Almería), ya que generalmente nacen de uno o dos círculos o de varios unidos, como por ejemplo las existentes en el aljibe del yacimiento medieval de Tíjola la Vieja (Tíjola, Almería) y las de los conjuntos rupestres del Collado del Pilarico (Senés, Almería) y Piedra Escrita (Chercos, Almería) (BARRERA y CRESSIER, en prensa). Otros tres ejemplos de cruces sobre peana triangular, las encontramos incisas en la fachada exterior del Palacio de Carlos V, en la Iglesia de San Matías (Granada) y sobre un sillar de la girola de la Catedral de Granada.

La cruz latina que nace del vértice de un ángulo (Lám. 2), y que encontramos tanto en los lienzos de muralla como en la cara interna de la Puerta de Fajalauza (Figs. 12 y I3), tienen sus paralelos más directos, con la localizada en una de las torres del recinto de Villa Vieja (Berja, Almería) y con la que hemos hallado en la fachada exterior del Palacio de Carlos V.

Respecto a nuestras cruces potenzadas (Figs. 14 y 17), sólo hemos encontrado similares en el Collado del Pilarico (Senés, Almería), mientras que del tipo papal/patriarcal y de Lorena (Figs. I5, 16 y I 7/Lám. 3), encontramos abundantes ejemplos en los ya citados yacimientos de Tíjola y Berja, también en el aljibe del Daimuz (El Ejido, Almería) (MARTINEZ, 1995: 21) y en el aljibe del Castillo de Escariantes (Ugíjar, Granada) ${ }^{3}$.

$3 \operatorname{Ver}($ CRESSIER, et alii., 1992: 147-I48), para un complemento bibliográfico, así como una lista de los yacimientos referidos. 
En resumen, pensamos pues que estos motivos poseen una función mágico-religiosa, cuya intención es la de purificar/cristianizar todo lo islámico, ya sean aljibes, murallas, rábitas, etc Esta idea de purificación, puede justificarse al considerar que la gran mayoría de los motivos cruciformes, se localizan en el tramo de muralla que hemos denominado Sector $A$, donde se encuentra la Ermita de San Miguel, antes Torre del Aceituno y que posiblemente fuese un santuario islámico (MALPICA, 1996: 75). Así mismo conocemos la existencia en la vertiente occidental del monte, en la parte interior de este tramo de la muralla, de una necrópolis islámica denominada "Qabrat al-Rawda min al-Bayyazin" (DIAZ y LIROLA, 1989: I I 3-I I4), constatada también a partir de algunos restos arqueológicos aparecidos en esta zona (BURGOS, LOPEZ y ROSALES, 1989) ${ }^{4}$. Creemos pues que los motivos cruciformes de la muralla, fueron realizados en este marco cultural, y en un momento crítico de tensiones y enfrentamientos entre el nuevo poder castellano y una población morisca cada vez más sometida y progresivamente menos numerosa, que intentaba no perder su identidad.

\section{Llave}

Situada en el Sector A de la muralla, aparece picada en el tapial, dispuesta verticalmente y con un tamaño aproximado de 38 cros. Se compone de un trazo recto con un círculo en su extremo superior y dos pequeños trazos perpendiculares a éste en el extremo inferior, que corresponden a las guardas de la misma (Fig.| 8/Lám. 5). Junto a esta aparece el anillo superior de otra, parcialmente desaparecida. El aspecto de esta llave es similar, a excepción de la simplicidad de las guardas, a varias de hierro forjado depositadas en el Museo Arqueológico y Etnológico Provincial de Granada ${ }^{5}$, a las encontradas en las excavaciones de Medina Elvira (GOMEZ, 988: Im.X, n 80-8I) y a la exis- tente en el Museo de Mallorca, procedente de la Coveta des Rovell (Escorca, Mallorca) (WV. AA., 1995: 90), todas ellas consideradas de época islámica.

La llave, es un motivo que aparece asiduamente en edificios nazaríes, y concretamente sobre las puertas de estos. La encontramos en las puertas exteriores de La Alhambra: Justicia, Siete Suelos y del Vino, aunque debieron llevarlas también la de las Armas y del Arrabal. Está presente en las puertas interiores del Generalife y posiblemente las llevasen las de los distintos palacios. Aparecen también en fortalezas pertenecientes al reino, como es el caso de la existente en el Castillo de Moclín (Granada) o la de la puerta del Cristo de la alcazaba malagueña. Se reconocen igualmente estas llaves formando parte del escudo real de la corona castellana, en edificios mudéjares (palacios y fortalezas) construidos durante el reinado de Alfonso Xl, simbolizando en este caso, plazas granadinas arrebatadas a Yusuf I.

Este fenómeno podemos detectarlo en algunas piezas de cerámica mudéjar procedentes de Paterna, Teruel, Manises y Talavera de la Reina, donde se representan llaves y manos de Fátima, posiblemente a imitación de cerámicas granadinas, como por ejemplo la que se encuentra en una tinaja del Museo Hispanomusulmán de la Alhambra (PAVON, 1985: 424, f.8 E,F,G; LLUBIÁ, 1973: 133, 138 y 167), en la que aparece estampillada una mano con antebrazo y en su interior una llave, $u$ otras similares de fragmentos de tinajas aparecidas en el subsuelo granadino, concretamente en Ainadamar y en las murallas de San Cristóbal (GARRIDO y GARCIA, 1987: Im. I I I n० 32 y 36). Así mismo, hallamos "unas llaves del Paraíso" mediante decoración aplicada en una tinaja murciana del siglo XIII y en un ataifor ceutí de loza dorada (NAVARRO, 1986: n 467; POSAC, I 980-8 I : 190, Im.VI/5).

\footnotetext{
4 Gómez Moreno nos dice en su Guía de Granada (Tomo II, página 284, anotación I725b): "Más amiba de este paraje ya próximo a la muralla de Don Gonzalo de que después hablaremos se han descubierto en 1892 multitud de sepulturas árabes, con motivo de cercar de tapias una parte del terreno que corresponde a la ermita de San Miguel".

5 Nos referimos a las depositadas en la "Reserva Visible" de este centro, y que están catalogadas con los números 387 y 428.
} 
Siguiendo a Pavón Maldonado, creemos que estas llaves simbolizan a la ciudad, ciudadela o fortaleza y conllevan la idea de posesión, con la variante que asociada a la mano, tienen el significado de que la ciudad o el objeto en sí (en el caso de una tinaja, contenedor de alimentos sólidos y líquidos, por ejemplo) gozaba de la protección Divina o de su eficacia contra el mal de ojo (HERBER, 1927; TORRES et 1996: 212, f. I 8; ETTINGHAUSEN, 1954: |48- I54).

En los relieves del siglo XV de la sillería baja de la Catedral de Toledo, se representan a los alcaides musulmanes de ciertas plazas nazaríes conquistadas, incluida Granada, haciendo entrega, en un acto simbólico, de la llave de la ciudad a Fernando I el Católico. El simbolismo e importancia que encierran estas llaves, queda patente actualmente en el poblado bereber de Amtodi, situado en la provincia marroquí de Goulime. Dominando este poblado, se sitúa en la cima de un saliente rocoso una fortaleza (actualmente abandonada) construida en el siglo XIII, a cuyo interior se accede por una puerta de madera, la cual aún se abre y se cierra con la llave original también de madera, que guarda con celo el padre del jefe del poblado, que fue anteriormente jefe, ya que el cargo es hereditario (CORTES, 1987).

La herradura es un motivo grabado que se presenta reiteradamente en la mayoría de los monumentos islámicos estudiados por nosotros, y que a veces resulta casi exclusivo, como por ejemplo en los aljibes de las fortalezas de Albox, Cantoria (Almería) y en algunos lienzos de muralla del Castillo de Tabernas (Almería). Igualmente hemos localizado gran abundancia de estos motivos en los conjuntos rupestres ya citados del Collado del Pilarico y de Piedra Escrita, y también en el Cerro del Mortero y Piedra de la Herradura en Tahal (Almería) (ACOSTA y MOLINA, 1964-65).

Tras observar la semejanza existente entre nuestros grabados de herraduras y otros rupestres de similar factura e idéntica temática en Marruecos (HERBER y DAVID, 1933; GATTEFOSSE, 1933), fechados algunos de ellos, como de época medieval a sub-actual, y con una relativa continuidad de producción hasta principios del siglo
XX, en un ámbito cultural evidentemente islámico, propusimos la posibilidad de datar los grabados parietales de nuestra zona de estudio en época medieval o moderna (después de 1500 e incluso después de 1578), estando entonces estos aljibes abandonados o anulada su función; y en cuanto a los grabados rupestres, no se debe excluir que hayan sido realizados en época islámica por poblaciones musulmanas (BARRERA y CRESSIER, en prensa).

Pero lo más interesante y que directamente afecta a la llave grabada en la muralla granadina, es que asociadas a los motivos de herraduras de los conjuntos rupestres antes aludidos existentes en nuestra zona de estudio, encontramos también llaves, como por ejemplo en el Collado del Pilarico y en el Cerro del Mortero (BARRERA y CRESSIER, en prensa: fs.2-3/4).

En base a todo lo anteriormente dicho, creemos pues, que la llave granadina, fue realizada tiempo después de la construcción de la muralla, pero aún en época andalusí, dado que es el único motivo no cruciforme picado en el tapial.

\section{Motivos incisos}

\section{Motivos arquitectónicos:}

Dentro de este grupo encontramos dos tipos, uno más numeroso formado por castillos y otro que consiste en un arco de herradura.

Si bien es cierto que todos los motivos arquitectónicos descritos por Gómez Moreno, no han sido localizados por nosotros, aunque pudieran ser algunos de ellos los Castillos I y 2 que a continuación describimos, sí podemos afirmar con toda certeza la localización de dos de ellos, concretamente un escudo con castillos en su interior y un arco de herradura.

Castillo I Está situado en el Sector A, en la cara exterior del lienzo de muralla existente entre la torre núm. 2 y la núm. 3 (Fig. I 9). Su altura máxima desde el actual nivel del suelo es de I 64 cros. La técnica en que se realizó es la incisión sobre el enlucido de la muralla. Representa un edificio de forma rectangular de 23 
cms. de ancho por $29 \mathrm{cms}$. de alto, coronado por siete trazos verticales y paralelos de aproximadamente $2 \mathrm{cms}$. de altura, que se suceden de derecha a izquierda, a modo de almenas. En el interior derecho del edificio aparecen una serie de líneas verticales y paralelas de trazado sinuoso y fino.

Castillo 2: Está situado en el Sector A, en la pared Este de la torre núm.3 (Fig.20). Su altura máxima desde el actual nivel del suelo es de $197 \mathrm{cms}$. La técnica en que se realizó es la incisión sobre el enlucido aún fresco. Representa un edificio de forma rectangular de $17 \mathrm{cms}$. de ancho por $20 \mathrm{cms}$. de alto. Está coronado por siete $u$ ocho almenas de forma rectangular acabadas en un plano inclinado hacia la izquierda, con una altura máxima de $5 \mathrm{cms}$. y una anchura que oscila entre 1 y 2 $\mathrm{cms}$. En su interior se dibuja un arco de medio punto, a modo de vano, desplazado hacia la derecha y cuya anchura máxima es de $8 \mathrm{cms}$. A este conjunto se le adosa, por este mismo lado, una torrecilla de $7 \mathrm{cms}$. de ancho por 2I,5 cms. de alto, rematada por un arco, que simula una cubierta semiesférica.

Castillo 3: Está situado en el Sector A, en la pared Sur de la torre núm.3 (Fig.2l/Lám. 6). La altura máxima que alcanza desde el actual nivel del suelo es de $148 \mathrm{cms}$. La técnica en que se realizó es la incisión sobre el enlucido aún fresco. Se trata de un triángulo invertido, cuya anchura máxima en la parte superior es de 75 cms., y con una altura aproximada desde el vértice de I m. Representa un escudo dividido en su interior en tres calles horizontales o fajas, en cada una de las cuales se dibuja un conjunto fortificado. Tanto la faja superior como la inferior han sufrido el desprendimiento de parte del enlucido perdiéndose algunos motivos que, según Gómez Moreno, existían anteriormente, tales como "phalos y estrellas de Salomón". Es pues la faja central la que se encuentra en mejor estado de conservación.

En estos tres conjuntos fortificados se repite un mismo esquema de organización, basado en una gran torre central flanqueada a ambos lados por dos torres de desigual tamaño, siendo las cercanas a la torre central las más pequeñas. No obstante existen algunas diferencias. Estas, tal vez vengan dadas por la continuada reducción del espacio de arriba a abajo, que obligó al autor del graffiti a simplificar cada vez más el esquema primario. Así pues, podemos ver como en la primera faja todas las torres representadas aparecen exentas; mientras que en la central aparecen todas adosadas entre sí, formando un conjunto muy compacto; y por último, en la faja inferior se representa la torre central, con sólo una torre de inferior tamaño adosada a cada lado.

Por tanto podemos afirmar, que primero se trazó el contorno del escudo, y posteriormente se dibujaron los motivos que aparecen en su interior.

El interior de las torres aparece relleno por un cuadriculado formado por dos líneas verticales y paralelas, cruzadas por otras horizontales que asemeja una mampostería de aparejo regular bastante torpe y poco realista. También aparecen las torres coronadas por almenas triangulares, generalmente en número de tres.

Castillo 4: Está situado en el Sector A, en el lienzo de muralla existente entre la torre núm.2 y la núm.3, más concretamente en la esquina de la torre núm.3, muy cerca de los graffiti anteriormente descritos (Fig.22). La altura máxima que alcanza desde el actual nivel del suelo es de I $10 \mathrm{cms}$. Está afectado en su parte central e inferior por el desprendimiento del enlucido y por restauraciones realizadas en la muralla. La técnica en que se realizó es la incisión sobre el enlucido aún fresco.

Representa una torre de $32 \mathrm{cms}$. de alto por $8 \mathrm{cms}$. de ancho, coronada por tres almenas triangulares de $3 \mathrm{cms}$. de altura. La torre arranca de una línea de muralla igualmente almena- da, a la que se le adosa por su lado derecho, una estructura que bien pudiera tratarse de otra torre, de anchura semejante, pero de una altura inferior. Este conjunto posee su interior relleno de un cuadriculado que simula un aparejo regular. Como podemos observar, este graffiti y el anterior estudiado (Castillo 3), poseen un trazo de ejecución y representan unas estructuras fortificadas de similares caracterís- 
ticas, que nos hace pensar que fueron realizadas en un mismo momento y por un mismo autor.

Hay que señalar, que a este graffiti se superponen las líneas de otros, que tal vez representen el posible velamen de alguna embarcación así como varias inscripciones que más adelante veremos.

Castillo 5: Está situado en el Sector C, en la pared Sur de la segunda torre que existe antes de la Puerta de San Lorenzo (Fig.23/Lám. 7). La altura máxima que alcanza desde el actual nivel del suelo es de $205 \mathrm{cms}$. Se localiza entre la primera y la segunda línea de mechinales que se aprecia en esa pared, ofreciendo unas dimensiones bastante considerables: $103 \mathrm{cms}$. de ancho por $62 \mathrm{cms}$. de alto. La técnica en que se realizó es la incisión del enlucido aún fresco. Se conserva prácticamente completo, aunque el desprendimiento del enlucido ha afectado al extremo inferior izquierdo del graffiti.

Representa una montaña (Lám. 8), en cuya cumbre se alza una gran torre de 13,5 cms. de alto por 8,5 cms. de ancho, coronada por almenas triangulares de $1,5 \mathrm{cms}$. de altura, de las que se conservan sólo dos. Esta torre está dividida por dos líneas horizontales y paralelas, en dos cuerpos de desigual tamaño, dibujándose en el inferior, una puerta de doble hoja en forma de arco de medio punto, mientras que el cuerpo superior se rellena con líneas verticales. La torre se une a la cima de la montaña mediante una serie de líneas paralelas y oblicuas hacia la derecha.

En las dos laderas se escalonan tres torres, habiendo desaparecido la torre más baja de la ladera izquierda debido al deterioro que sufre esta parte del graffiti. El interior de éstas aparece relleno de trazos que no permiten distinguir un dibujo definido. Poseen una altura de $10 \mathrm{cms}$. y una anchura de $3 \mathrm{cms}$., y están coronadas por tres almenas de I,5 cms. de alto. A lo largo de la ladera derecha, se dibujan unos pequeños trazos verticales de aproximadamente $1 \mathrm{~cm}$., que simulan una muralla almenada.
En el interior de la montaña existen una serie de formas curvas, triangulares $y$ ante todo rectangulares, que contienen un punto o círculo. Creemos que estas formas representan casas de una población que ocupa la falda de este monte. Entre el caserío se desarrolla un sendero en zig-zag, que parte desde la base y llega hasta la puerta de la gran torre situada en la cumbre. A media altura el camino se bifurca, tanto hacia la derecha como hacia la izquierda, en dirección a las torres centrales de cada ladera.

Todo el conjunto aparece rodeado, excepto por su extremo izquierdo por una muralla con almenas, que son simples trazos verticales de I ó $2 \mathrm{cms}$, mientras que en la parte inferior se intercala una torre de $4 \mathrm{cms}$. de ancho por 9 cms. de alto, coronada por almenas triangulares y una estructura casi cuadrada, que se asemeja a un matacán (Lám. 9). En el interior de la torre se dibuja una puerta de doble hoja en forma de arco de medio punto.

Y por último, fuera de esta muralla, pero unido a ella por la base, con un trazo horizontal, se levanta otra torre de $6 \mathrm{cms}$. de ancho por $15 \mathrm{cms}$. de alto, coronada por cinco almenas triangulares, que bien pudiera representar una torre albarrana (Lám. 9).

Creemos interesante señalar que junto a este graffiti localizamos un primer boceto (Castillo 6) del mismo, que el autor realizó y desechó más tarde borrándolo con trazos anchos y zigzagueantes (Lám. I0).

Tras la descripción de estos motivos arquitectónicos, podemos concluir con la distinción de tres tipos de castillos, con claras diferencias entre sí:

- Un primer tipo, representado por los Castillos 1 y 2 de proporciones rectangulares y esquema sencillo. Por su aspecto estos castillos recuerdan a las típicas torres de alquería de al-Andalus, y a una serie de fortalezas del Norte de África y de Oriente, representadas en algunos mapas del siglo XIII (en lo que se refiere al elemento de torre con cubierta semiesférica), tal como pode- 
mos ver por ejemplo, en las torres de la Mezquita y Ribat de Susa (Túnez) (PAVON, 1996: 13-79);

- Un segundo, más complejo, (Castillo 3 y 4), son estructuras fortificadas que reproducen el esquema de otros motivos existentes en escudos nobiliarios y cerámicas cristianas del siglo XIV, donde se representan castillos formados por una gran torre central flanqueada por torres menores (LLUBIÁ, 1973: 124, 128 y 133; PASCUAL y MARTI, 1986: I3 I , fg.7I).

Graffiti similares a los nuestros, los encontramos en Cataluña, concretamente los existentes en Castellfollit de Riubregós (Afloja, Barcelona), donde se representa un gran recinto amurallado intercalado por torres. Tanto las murallas como las torres aparecen coronadas con almenas triangulares, y sus interiores se rellenan con un cuadriculado que asemeja un aparejo bastante torpe e irreal. Estos han sido fechados entre los siglos XIII y XIV (VV.AA., I 98I: 297-299, fs.30, 31 y 32).

Otros de iguales características, son los graffiti de torres hallados en el Castillo de Denla (Alicante) de la segunda mitad del siglo XIII y primera del XIV, también coronadas con almenas triangulares y tosco aparejo (BAZZANA et alii., 1984: 40, fs.32 y 33).

Ya por último, y de época más tardía (XVI$X V I I)$, contamos con los graffiti de varias torres aparecidas en los muros de la Capilla de La Trinidad en la Catedral de Mallorca, dibujadas con trazo "infantil" por una mano inexperta (BERNAT y SERRA, 1989: fs.CT2 y CT5).

- Los Castillos 5 y 6 constituyen el tipo tercero, y nos muestran una población rodeada por un doble recinto fortificado que se asienta a los pies de una gran fortaleza. Rea- lidad ésta, que parece ser bien conocida por el autor del graffiti, y de la que tal vez formase parte. Encontramos cierto parecido con un dibujo de la ciudad de Granada de 1548, inserto en la obra de Pedro Medina, el "Libro de las Grandezas y Cosas Memorables de España" (GALLEGO Y BURIN, 1982: 14). Pero sobre todo, resulta sorprendente, la enorme similitud de nuestro graffiti y una antigua miniatura del Códice de Privilegios de Orihuela (A.H.N.), que representa a esta ciudad, e ilustra la obra de Pedro Bellot, "Los Anales de Orihuela" (ALOMAR, 1972; MAS Y GIL, 1969).

Hemos de considerar este graffiti como uno de los más importantes hasta ahora descritos, no sólo por los distintos elementos que lo forman, sino por lo que en sí representa, es decir, uno de los esquemas de defensa más generalizado en las poblaciones islámicas de al-Andalus, basado en alcazaba más recinto urbano amurallado, como es el caso de Málaga, Almería o la misma Granada.

Arco de herradura: Está situado en el Sector C, en la cara exterior del segundo quiebro que hace la muralla después de la Puerta de Fajalauza (Fig.24/Lám. I I). En esta zona la muralla formaba parte de la fachada posterior del desaparecido Convento de San Diego, construido en el siglo XVII y derribado durante la desamortización, del que quedaban restos de sus ventanas en los huecos abiertos en la cerca, recientemente restaurada. La técnica en que se realizó es la incisión sobre el enlucido aún fresco. Se trata del arco de herradura que nos describió Gómez Moreno, enmarcado en un rectángulo de 54 cms. de alto por 75,5 cms. de ancho, eso sí con despiece de dovelas dirigidas al centro del mismo ${ }^{6}$.

Graffiti de arcos de herradura, los hemos encontrado recientemente en el enlucido de las paredes de la red de alcantarillado de Madi-

\footnotetext{
6 Tras nueva visita al conjunto, y recientes excavaciones realizadas en la zona con el consecuente rebaje del terreno (RUIZ y PADIAL, 200I), constatamos que se trata del arco de herradura descubierto por Gomez Moreno. El dibujo y la fotografía que aportamos responde al momento en que lo descubrimos y por tanto anterior a la excavación realizada. El dibujo completo de este arco ha sido publicado junto con otros similares descubiertos, por los arqueólogos que llevaron a cabo la excavación referida.
} 
nat al-Zahra. En este caso, estos constituyen el documento gráfico de unas explicaciones sobre el proceso constructivo de algunos edificios de la ciudad palatina. Los arcos están realizados a compás, y aparecen a veces dobles o formando arcadas de tres ${ }^{7}$. A estos hay que sumar el esquema de un arco trilobulado enmarcado y con dovelas indicadas, existente en la galería o camino de ronda situado en el costado de poniente del Salón Rico o de Abd al-Rahman III (VELÁZQUEZ, 1912: 90, f.50; LOPEZ-CUERVO, 1985: 109, f.72), y el trazado en una yesería procedente de Mojácar la Vieja (Almería) (CARA, 1923: 159), con función decorativa.

Por lo que respecta a nuestro arco de herradura, podemos considerarlo como la expresión gráfica de verdaderas lecciones de albañilería, tal como a quedado demostrado con el descubrimiento en este mismo paño de muralla (tras recientes excavaciones arqueológicas), de una docena de grafitti de arcos de herradura similares al nuestro (RUIZ y PADIAL, 200I).

Estos grafitti de arcos muestran en su interior una serie de líneas horizontales dobles y en forma de "T" que parecen representar, según los autores del artículo referido, una especie de plantilla o "escantillón" utilizado para el trazado de estos arcos (Fig. 3 I).

\section{Ballesta}

Situada a una altura máxima del nivel del suelo de 7 I cros., aparece incisa en el enlucido fresco de la muralla. Tiene forma de ' $T$ ', siendo el trazo vertical doble en su extremo inferior, y los brazos horizontales, unidos por debajo, con un arco (Fig.25).

Los paralelos más directos que encontramos del graffiti granadino, los hallamos por una parte, en numerosos grabados rupestres, y por otra, en graffiti y marcas de cantero existentes en diversos edificios medievales.

En la mayoría de las publicaciones consultadas, a los motivos que nos referimos, se les denomina figuras en forma de la letra "phi", es decir, figuras que consisten en una cruz, cuyos brazos horizontales se unen, la mayoría de las veces por arriba, mediante un arco. Algunos de estos grabados, descubiertos y estudiados a principios de siglo, fueron erróneamente datados como prehistóricos, pero actualmente hemos de considerarlos medievales o de época moderna. Entre estos, encontramos los grabados de Baños de Alicún (Granada) (GARCIA y SPAHNI, 1958: Im. I I I), los situados en la cubierta del dolmen del Barranco de Espolia (Gerona), los grabados de la Roca de los Sacrificios de Campmany (Gerona) ${ }^{8}$, los de Ferraduras de Bemfeitas (Oliveira das Frades, Portugal) y los grabados gallegos de la Pedra de las Cruces (Mougas) ${ }^{9}$, entre otros. Pero lo más sorprendente, es que aún hoy, se siguen considerando como prehistóricos ciertos grabados publicados recientemente, cuando con gran claridad podemos adscribirlos a momentos históricos: es el caso de los grabados de "Cueva Perica" (Alfacar, Granada) (ZAPATA, ANIBAL y PACHON, 1995), tal como a puesto de manifiesto Julián Martínez. Esta confusión cronológica, viene producida por la utilización por parte de muchos estudiosos, de un corpus de datación errónea y nunca discutido, que tiene su origen en una serie de grabados estudiados a principios de siglo, existentes en las cubiertas de algunos dólmenes, que fueron considerados como prehistóricos, simplemente por el hecho de estar realizados sobre estos monumentos megalíticos ("determinismo del soporte"). Proponemos por tanto, la necesidad de realizar un depurado, actualizado y sistemático estudio de estos grabados rupestres, con una referencia de partida, basada en la comparación, con los nume-

7 En (BARRERA, CRESSIER y MOLINA, 1999), ver los paneles G I/P8, G I/P9 y G2/P7.

8 En (BARRIS, 1983), ver las figuras II,I2 y 20 de la cubierta del Dolmen del Barranco de Espolia y el símbolo n I de la Roca de los Sacrificios de Campmany.

9 En (ANATI, 1966), ver la figura 67 para los grabados de Ferraduras de Bemfeitas y la figura 70 para la Pedra de las Cruces. 
rosos graffiti y grabados aparecidos en edificios de época medieval y moderna.

En Tarragona, en los grabados rupestres de Riera (VILASECA, I970: Im.I), encontramos una forma de similar aspecto a los anteriores, cuyos estudiosos apunta la posibilidad, de que se trate de una ballesta. Así mismo, y en nuestra zona de estudio, concretamente en Piedra Escrita hallamos formas de aspecto antropomorfo, que podríamos considerar como ballestas (BARRERA y CRESSIER, en prensa: fs.2-6/7).

Respecto a los motivos parietales en edificios medievales, diferenciamos dos formas que se pueden relacionar con nuestro graffiti de la muralla:

Una primera, de aspecto similar a los grabados rupestres antes referidos, que localizamos por ejemplo en la Catedral de Orense (FORTEA, 199 I: fs.A I0,Al I y Al2) y en marcas de cantero de la Mezquita de Córdoba (OCAÑA, 1986: Im.VIII, n 257 y 267); y una segunda forma, algo más compleja constituida por graffiti que representan armas (ballestas y arcos con flecha).

Dentro de este segundo grupo, incluimos los simples arcos (con flecha o dardo) del Castillo de Denla (BAZZANA et alii., 1984: 40, 0.32) y del Castillo de Petrer (Alicante) (s.XVI) (NAVARRO, 1993: 99 y 112, fs.4, 13), las ballestas más simples del Castillo de Petrer (NAVARRO, 1993: 99 y 109, fs.4, II) y de Castell D'Oroners (Ager, Lérida) (s.XIV) (BERTRAN y FITE, 1984-85: 402, Im.4), y las más complejas de Castellfollit de Riubregós (VV.AA., 1981: 303, 040) y de la Catedral de Mallorca (s.XVI) (BERNAT, GONZALEZ Y SERRA, 1986: 047).

Resumiendo, podemos decir de nuestro graffiti, que en líneas generales participa del mismo aspecto que presentan el resto de los motivos antes aludidos, y que en particular, posee las características de los graffiti de arcos con flecha, aunque el hecho de que el trazo vertical sea doble, nos hace pensar que podría tratarse de una ballesta, tal como las que podemos ver en Castellfollit de Riubregós, similares también, a las dibujadas en las Cantigas de Santa María (s.XIII) (DE CARLOS, 1973), en las pinturas murales del Partal de La Alhambra (s.XIV) (GOMEZ-MORENO, 1970) y en los frescos de la Sala de Batallas del Monasterio del Escorial (s.XVI), que representan la batalla de la Higueruela (|43|).

\section{Estrella}

Ya nos informó Gómez-Moreno de la presencia en la parte superior del escudo con castillos, antes descrito (Castillo 3), de estrellas de Salomón, hoy desaparecidas. En cambio, hemos podido localizar en este mismo tramo de la muralla y a una altura aproximada de un metro del nivel del suelo, sólo la mitad superior de una estrella de seis puntas (dos triángulos entrelazados), debido al desprendimiento del enlucido (Fig.26).

La estrella, tanto de cinco como de seis puntas, ha sido considerada como un símbolo contra el mal de ojo, que encerraría poderes mágicos o astrológicos.

La estrella de seis puntas o sello de Salomón, aparece representada, posiblemente con la simbología antes referida, en numerosos objetos, tales como escudos, como por ejemplo los dibujados en Las Cantigas de Santa Maria; en una fusayola hallada en Almería (FLORES y MUÑOZ, 1993: 150); en vajilla doméstica, como las dibujadas en ataifores de Madinat al-Zahra (RETUERCE y ZOZAYA, 1986: I I I-1 I3, fs.27/9, 29/6; PAVON, 1972: 209,2 I 5, fs. I I, 17) O en el interior de una mano de Fátima de un plato de Paterna (PASCUAL y MARTI, 1986: 162, 090/2), pintadas con manganeso en jarras murcianas (NAVARRO, 1986 179,413, n³82,413) y estampilladas como las de una tinaja procedente del Castillejo de los Guájares (Guájar Faragüit, Granada) (CRESSIER, RIERA y ROSELLO, 1992: 19,07/3) y de Alcalá la Vieja (Alcalá de Henares) (PAVON, 1985: 443,015/P), que reproducen un tipo de estrella muy similar al que muestra un sello de estampar hallado en la Alcazaba de Almería (FLORES y MUÑOZ, 1993 |41, 149).

Podemos comprobar, a través de estos objetos, como este signo con su propia simbología, formaba parte de la vida cotidiana de las gentes de al-Andalus, tal como hoy en día, en nume- 
rosos hábitat y qars norteafricanos, se representa junto a la figura de la Mano de Fátima.

A esta expresión grafica de carácter popular y a la vez cargada de gran simbología (contra el mal de ojo, mágica, astrológica, esotérica...), respondería nuestro graffiti, así como posiblemente los numerosos ejemplos encontrados en la bibliografía que hemos consultado:

- Figuras de estrellas de seis puntas, las encontramos incisas en lajas de pizarra, de la ciudad islámica de Vascos (Navalmoralejo, Toledo) (IZQUIERDO, 1994: I72, F.62/2), en el Castell d'Oroners (BERTRAN y FITE, 1984-85: $417,1 \mathrm{~m} .15)$, grabada sobre roca en Piedra Escrita (BARRERA y CRESSIER, en prensa: 62/I) y como marcas de cantero en el Castillo de la Mola (Alicante) (NAVARRO, 1993: 66, 63), en el Castillo de Monzón (Huesca) (L'AÑO, RAMON y VILLAR , 1969: 307)...;

- Graffiti de estrellas de cinco puntas, más numerosas que las anteriores, las hallamos en la Alcazaba de Almería (CARA, 1990: $176-$ 177, Im.47), en el Castillo de la Mola y en el de Petrer (NAVARRO, 1993:41, I01, 109-1 I0, I I2, fs. 6, I I-13), en el Castell d'Oroners (BERTRAN y FITE, 1984-85: 4II, im. I0A), en el Castillo de jubera (La Rioja) (FERNANDEZ, et alii., 1987: 4I2, 6.3), en el Campanario de la Catedral de Mallorca (BERNAT, GONZALEZ y SERRA, 1986: $n^{\circ} 12,13$ y 26); como marca de cantero aparece en el castillo jordano de Jirbat al-Mafyar (PAVON, 1980: 63) y en la Mezquita de Córdoba (OCAÑA, 1986: 78, Im.VIII, n²63); también aparecen en grabados rupestres líbicobereberes de Marrakech (RODRIGUEZ, I 987- 88: n³69), así como en la Roca de las Bruixes (Prats, Andorra) (DIEZ-CORONEL, 1986-87: 242, f.6|4).

\section{Motivos epigráficos}

Manuel Gómez Moreno, cuando visitó este conjunto, pudo localizar diez inscripciones en gran parte legibles, de las que nos dejó su transcripción:

" 0 . ...nos don alfon por la gra de dios Rey de... $2^{\circ}$. sepa todos qntos esta cta oyeren... $3^{\circ}$....nos don alfon...la gra de dios

$4^{\circ}$. de nos don ferrando por la gra de dios obyspo

$5^{\circ}$. de nos don ferrando...gra

$6^{\circ}$. de nos don al fon por la gra de dios rey de castillo de tolledo / de leon de seuilla de cordoua de iohe de murcia de algecira- / de g'llizia de ...año de mili...

$7^{\circ}$. esta es...baeza...vida co mucha honrra...

$8^{\circ}$. ...en cordoua a la collacion de santo domingo leve (añade"el belaco")...seys dineros $9^{\circ}$. de nos los catybos q son del Rey

$10^{\circ}$. Daueicim (lo suprime)."

En nuestras visitas a la muralla, pudimos localizar seis inscripciones, de las cuales tres, nos resultan difíciles de transcribir, en cambio, las otras restantes posiblemente correspondan a las inscripciones $8^{\circ}$ (segunda línea), 9' (Lám. 12) y I0' que nos dejó Gómez Moreno.

Están escritas en castellano, con caracteres de la primera mitad del siglo XIV, y parecen corresponder a fórmulas notariales posiblemente realizadas por cautivos cristianos que participaron en la construcción de la muralla. La datación anterior, ofrecida por Gómez Moreno, se fundamenta en que el rey Alfonso referido en las inscripciones, debe ser Alfonso Xl, que fue quien conquistó la plaza de Algeciras en el año 1342.

En principio aceptamos esta hipótesis, a la espera de que se realice un detenido análisis paleográfico de las mismas. Para ello, hacemos una llamada desde aquí, poniendo a disposición de los estudiosos en la materia, la documentación gráfica que poseemos de las mismas.

Conocemos a través de las fuentes escritas, que en época de Almanzor se utilizaron cautivos cristianos procedentes de Castilla y de otras zonas, como peones en la construcción de la Mezquita de Córdoba. Son así mismo abundantes, las noticias sobre la utilización de cautivos en el siglo XIII, en labores agrícolas, tales como arar, cavar, guardar bestias y partir leña, en industrias caseras, como criados y en oficios de la construcción, como levantar tapias, labrar piedra, enlucir con yeso, serrar madera y machacar hierro. Estos cautivos encerrados en mazmorras, eran sacados durante el día para rea- 
lizar estas tareas, mientras que las noches las pasaban en aquellas lúgubres estancias, como ocurría en el siglo XV por ejemplo, con los prisioneros de las mazmorras de los castillos de Montefrío y Alhama, o los de las mazmorras de la Alhambra y de las situadas frente a la Puerta de los Siete Suelos, según nos informa ya en el siglo XVI Mármol Carvajal y Hoefnagel en uno de sus grabados incluidos en la obra Civitates Orbis Terrarum (TORRES, 1944).

El elemento humano ha sido escasamente tenido en cuenta, a la hora de abordar el estudio de la construcción de un edificio. Lejos de esta tendencia, se sitúa el trabajo realizado por Manuel Ocaña Jiménez sobre la Mezquita de Córdoba, donde nos expone el cuadro personal directivo de toda obra de carácter oficial que se realizaba en la capital del Califato en época Omeya (OCAÑA, 1986).

El cuadro personal técnico sería el siguiente: la alta dirección con carácter nominal u honorífica estaría en manos del Sahil al-abniya (jefe de las construcciones estatales), que generalmente regentaba el cargo de wazir (ministro) o hachib (chambelán); la dirección efectiva o técnica, estaría en manos del Sahil al-bunyan; la inspección de la obra era llevada a cabo por el Naziru-l-bunyan, y por último la ejecución de la obra era efectuada por los alarifes ('Urafa' al-banna'in: arquitectos;'Urafa' al-muhandisin: ingenieros y 'Urafa' al-sunna: artesanos) y un numeroso grupo de peones.

Este esquema de época califal no sabemos si se mantendría en época nazarí, dada la escasez de estudios sobre el tema. Tomando como punto de partida este cuadro, y aplicándolo a la construcción de la muralla granadina, sí podemos afirmar que se darían dos de las fases anteriores, concretamente la primera y la última fase. La alta dirección de la construcción estaría en manos del hachib Ridwan por orden de Yusuf I, y en la última fase o ejecución de la obra, podemos detectar la participación del grupo de peones, constituido tal vez, por cautivos cristianos y posiblemente por obreros asalariados de la ciudad. Estos últimos, los encontramos como nos informa A. Malpica, en el caso de reformas realizadas en el Castillo de Salobreña (Granada), donde "los materiales y los jornales eran pagados por la administración granadina, mientras el peonaje y las bestias para el transporte los entregaba Motril y las otras alquerías, un día cada lugar" (MALPICA, 1982-83: 196; MALPICA, 1996: 188).

\section{Motivos Geométricos}

El principal motivo, consiste en una forma cuadrangular de aproximadamente $18 \mathrm{cms}$. de lado, cuyo interior se divide en cuatro cuadrantes casi iguales, atravesados por diagonales a derecha e izquierda.

Se localiza en el Sector A de la muralla, y a una altura máxima del nivel del suelo de 43 cms. (Fig.27/Lám. 13).

Los paralelos más directos que encontramos de nuestro graffiti, los encontramos por orden cronológico, entre los graffiti localizados en la red de alcantarillado de Madinat al-Zahra (mediados del s.X) (BARRERA, CRESSIER y MOLINA, 1999: fs. GI/PI, G I /P3 y G4/PI), sobre un fragmento desprendido del enlucido de yeso que recubre las paredes de una de las casas de Madinat Siyasa (ss.XII-XIII) (Cieza, Murcia) $1^{\circ}$ y por último de fechas más tardías, en el Castillo de Petrer (s.XVI) (NAVARRO, 1993: 99,103, fs.4 y7) y en la cara externa de uno de los sillares de la girola de la Catedral de Granada.

En el estudio que realizamos sobre los cuadriculados de Madinat al-Zahra, concluimos diciendo que podrían tener en un mismo ámbito cultural, tres significados compatibles: arquitectónico, profiláctico y lúdico.

Por lo que respecta a nuestro graffiti, creemos que podríamos atribuirle un significado

I0Agradecemos a Julio Navarro Palazón la documentación gráfica facilitada sobre este graffiti, así como la correspondiente al guerrero que en el apartado siguiente comentamos. 
lúdico, tal vez relacionado con algún tipo de juego de rayas que sirviese de entretenimiento a los obreros participantes en la construcción de la muralla, dada la similitud que muestra con los tableros del juego denominado "alquerque", representado a menudo en la iconografía medieval y concretamente en el Libro de acedrex, dados e tablas de Alfonso X (ANER, 1874), así como con los descubiertos en algunos yacimientos arqueológicos (COSIN y GARCIA, 1998).

En este mismo sector de la muralla, y entre una serie de líneas de difícil interpretación, encontramos un triángulo invertido cuyo interior se rellena con un rayado vertical. Su aspecto nos recuerda al velamen de alguna embarcación o a un escudo, tal vez como el que pertenecía al "caballero cristiano con capacete/bacinete, lanza y triangular escudo", que en su día vio Gómez Moreno.

Por último, y en el tramo de muralla que se levanta entre la Ermita de San Miguel y la Puerta de Fajalauza, localizamos algunos círculos trazados con compás, pudiéndose apreciar las marcas dejadas por la punta del mismo, estando el enlucido aún fresco. Círculos de este tipo los encontramos en la cúpula de la Puerta de las Armas de la Alhambra (RODRIGO y CALANCHA, 1990: Ims.30-3I), en la red de saneamiento de Madinat al-Zahra (ya citados), así como otros tantos localizados en los edificios de esta ciudad califal, ahora en fase de estudio.

\section{Motivos zoomorfos}

Gómez Moreno nos habla de la existencia de "caballos enjaezados y corriendo", "ya de ciervos, pájaros, peces, perros y otros animales". También nos informa de un "pavo real".

Como única muestra de los abundantes animales que parece que había grabados en el enlucido de la muralla, solamente hemos localizado un caballo enjaezado (Fig.28 / Lám. 14) y parte de otro algo más tosco.

El primero se encuentra bastante bien conservado, y se situa como la mayoría de los graffiti que estudiamos, en el Sector A, a una altura de $80 \mathrm{cms}$. del actual nivel del suelo. El cuerpo aparece bien definido, con seis líneas verticales de trazado sinuoso en su interior. Se distinguen claramente la línea superior que dibuja el cuello del animal, la cabeza y tan sólo una de las patas delanteras.

Consideramos la cabeza como el elemento más realista del dibujo, y la que define a este animal como un caballo. Se dibuja perfectamente la oreja de forma picuda, la cara más ancha y el hocico ligeramente caído.

Entre los ejemplos de graffiti de caballos que hemos encontrado en la bibliografía consultada, hallamos una gran similitud con algunos de los caballos del Castell d'Oroners y de Castellfollit de Riubregós (BERTRAN y FITE, 198485: 409, f9; WV.AA., 1981:296, f.29), en lo que se refiere al aspecto del cuerpo de los mismos, en cambio, no observamos en estos motivos el realismo de la cabeza de nuestro caballo, salvo en el graffiti de un caballo montado por un guerrero aparecido en una de las casas de Madinat Siyasa.

El otro zoomorfo que hemos localizado parcialmente, parece corresponder también a un cuadrúpedo, aunque solamente podemos ver la cabeza con hocico, oreja picuda, y un cuello largo en donde parecen distinguirse dos líneas pequeñas y paralelas que podrían ser las riendas. Este es de trazado más tosco y menos realista que el anterior.

\section{Motivos navales}

Contamos con un ejemplar completo situado en el Sector A de la muralla, y a una altura máxima del actual nivel del suelo de $127 \mathrm{cms}$. (Fig. 29). Consiste en una embarcación compuesta por un casco largo trazado por tres líneas horizontales y paralelas que se unen en curva por sus extremos. Tanto de la primera como de la segunda línea horizontal, surgen a lo largo de todo el casco catorce líneas paralelas y oblicuas que terminan en una forma almendrada y que representan los remos de la embarcación.

La nave que presentamos podríamos identificarla con el qarib (plural, qawarib), en castellano cárabo, que aparece en las fuentes escri- 
tas. Pedro de Alcalá lo identifica con "barca de nao",'"barca de passage",',barca de pescar", "batel", "canoa naue de un madero" y "copano barco pequeño".

Según Lirola Delgado, estos cárabos eran pequeñas embarcaciones auxiliares de gran ligereza y facilidad de maniobra, que acompañaban y permitían a las grandes naves de guerra realizar desembarcos de tropas en lugares a los que no podín acceder, y a las mercantes les posibilitaba la carga y descarga en los puertos que no estuviesen preparados para acoger naves de considerable calado. Así mismo eran utilizadas en la actividad pesquera.

Otro término que aparece igualmente en las fuentes escritas y que define una embarcación de similares características que la anterior; es el zawraq (plural, zawariq), y que Pedro de Alcalá también traduce como "barca" (LIROLA, 1993; DE BLUNES y MARTINEZ, 1993).

Entre los abundantes ejemplos de graffiti de embarcaciones existentes en las publicaciones consultadas, no hemos encontrado ninguna similar a nuestra barca, ya que todas ellas portan algún tipo de velamen, frente a la nuestra que no lo tiene. Pero sí hemos de decir que hay cierta similitud con los graffiti de galeras del Castillo de Denia, donde el casco de las embarcaciones y la disposición de los remos son muy similares al de nuestro motivo. Es interesante resaltar en nuestra embarcación el detalle con que se han dibujado los remos, frente a los del resto de las embarcaciones que aparecen en otras publicaciones, que son simples líneas sin terminación alguna, intencionadamente realizadas para producir el efecto de que los remos están sumergidos en el agua.

A pesar de esta esterilidad de paralelos, sí hallamos, aunque en un momento histórico bastante anterior; estas embarcaciones auxiliares sin vela junto a grandes naves, representadas en sendos "bacini" fabricados en Mallorca a fines del siglo $\mathrm{X}$ o a lo sumo muy a inicios del siglo $\mathrm{Xl}$, e insertos como elementos decorativos, en los paramentos de la iglesia de San Piero a Grado en Pisa. Nos referimos a los bacini $n^{\circ} 59$ y $n^{\circ}$ 19, y más concretamente al primero de estos (BERTI, I992; BERTI, PASTOR y ROSELLO, 1993).

En el estudio realizado por Roselló Bordoy sobre los mismos, considera a estas naves como embarcaciones auxiliares y propone que tal vez sean los qawarib citados en las fuentes históricas.

Un segundo motivo naval podría ser el triángulo invertido cuyo interior aparece relleno de líneas verticales, que ya incluimos en el grupo de "Motivos Geométricos", y que como indicamos, podría tratarse de la vela de una posible embarcación, dada la similitud que ofrece con las velas de algunas galeras de graffiti mallorquines y con las referidas anteriormente de Denia.

Y para concluir este grupo, incluimos lo que podría ser la arboladura de una enorme embarcación con una gran vela que parece estar recogida. De este graffiti ya indicamos su situación junto al Castillo 4, y a una altura máxima del actual nivel del suelo de I5I cros. (Fig.30).

\section{CONCLUSIONES}

Podemos afirmar que hemos cumplido uno de nuestros principales objetivos, que era el documentar gráficamente y estudiar este interesante conjunto de graffiti existente en la muralla nazarí de Granada, hasta ahora desconocido para unos y olvidado por otros. A pesar del constante y progresivo deterioro que sufre el monumento, hemos podido localizar un gran número de motivos, aunque desgraciadamente no hemos localizado algunos de gran interés que pudo ver Gómez Moreno, concretamente nos referimos a un pavo real y a una "Mano de Fátima" I I similar a la existente en la Puerta de la Justicia de la Alhambra, según este

I I En fase de estudio se encuentran una serie de manos picadas en el tapial de la Torre de Cúllar-Baza (Granada) y otra impresa en un lienzo de muralla del Castillo de Dólar (Granada). 
autor. Pero nos sentimos satisfechos por la gran diversidad de los que hemos hallado.

Es la variedad temática de los graffiti lo que hace importante a este conjunto, ya que ofrece claros elementos del mundo y de la realidad medieval, a través de la representación de castillos, del arco de herradura, de caballos enjaezados, de la ballesta e incluso de los propios motivos epigráficos. Así mismo, la religiosidad y simbología de la época queda plasmada con los diversos cruciformes, la estrella y la llave.

Igual de interesante nos resulta el poder diferenciar dos momentos cronológicos distintos en la factura de los mismos: por una parte, los motivos incisos sobre el enlucido aún fresco, realizados durante la construcción de la muralla, en la primera mitad del siglo XIV, y por otra parte, los motivos picados en el tapial (algunos cruciformes están superpuestos a otros incisos) realizados posiblemente a lo largo del siglo XVI, según podemos constatar a partir de los abundantes paralelos estudiados por nosotros y ya citados anteriormente en el texto.

También hemos querido acercarnos en lo posible, al elemento humano ejecutor de estos graffiti y constructor de la muralla. Para ello hemos contado con el apoyo de las fuentes escritas, que nos hablan de la fecha aproximada de la construcción de la muralla, situándola durante el reinado de Yusuf I (|333-|354). Así mismo, sabemos que la alta dirección de las obras estuvo en manos de Abu-l-Nu caym Ridwan, que ocupaba el cargo de hachib del sultán. Creemos que el numeroso grupo de peones que participó en la obra, estaría constituido por obreros asalariados posiblemente de la ciudad, es decir un elemento humano islámico que delata su presencia con ciertos graffiti cargados de gran simbología o tradición, como es la estrella, el pavo real, la "Mano de Fátima", la llave, determinadas grafías árabes, el arco de herradura..., y tambien por un grupo de obreros formado posiblemente por cautivos cristianos que participaron igualmente en esta obra, dejando su testimonio con graffiti tales como el escudo con castillos en su interior (Castillo 3) y las inscripciones castellanas en letra gótica cursiva que recuerdan a los documentos públicos de esta época (no hay que olvidar la importante inscripción 9a: "de nos los catybos q son del Rey").

En esta conclusión hemos de destacar el graffiti correspondiente al Castillo 5, que representa a una población que se asienta en la falda de una montaña y a los pies de una gran fortaleza, rodeada de un doble recinto amurallado intercalado por torres. A parte de los variados elementos de la arquitectura castrense que aparecen (torres coronadas con almenas triangulares, doble recinto de muralla, puertas con arcos de medio punto, torre con matacán y posible torre albarrana), lo más interesante es que estamos ante la representación de uno de los sistemas defensivos más usuales utilizado en algunas poblaciones de al-Andalus, y que bien podría tratarse de la propia ciudad de Granada.

Para terminar, solamente decir que con este breve estudio hemos intentado dar a conocer un importante legado de manifestaciones de carácter popular de la Granada islámica, oculto y olvidado hasta hoy, en la muralla nazarí del Albayzín.

\section{BIBLIOGRAFÍA}

ACOSTA, P.y MOLINA FAJARDO, E. (1964-65): "Los grabados rupestres de Tahal (Almería)", Noticiario Arqueológico Hispánico. N VIII-IX. Madrid, pp. 53-63.

ALBERTI, A.;BERNAT, M.;GARCIA, N.;GONZALEZ, E.;OLIVER, G.;MOREY, A. y SERRA, J. (1986): "Estudis sobre la torre deis Enagistes (Manacor)", Quaderns de Ca La Gran Cristiana. No 7. Palma de Mallorca.

ALMAGRO GORBEA, A. y ORIHUELA UZAL, A. (1997): La casa nazarí de Zafra. Granada.

ALOMAR, G. (1972): "Los determinantes militares en la evolución urbanística de la ciudad", Castillos de España. Revista de la Asoc. Esp. Amigos de los Castillos. Segunda Epoca, $N^{\circ}$ 7. Madrid, pp. 2- II.

ANATI, E. (1966): "El arte rupestre Galaico-portugués", Simposium Internacional de Arte Rupestre. Barcelona, pp. 195-254.

ANGELÉ, S. y CRESSIER, P. ( 1992): "Velefique (Almería):Un ejemplo de mezquita rural en Al-Andalus", Estudios de Arqueología Medieval en Almería. Almería, pp. 24l-263.

ARTE, R. (1984): Historia de España dirigida por Manuel Tuñón de Lara, España Musulmana (Siglos VIII-XV). T. III, Barcelona. 
AZUAR RUIZ, R. (1989): La Rábita Califal de las Dunas de Guardamar (Alicante). Alicante.

BARRERA MATURANA, J. I. (en prensa): "Los graffiti de la muralla islámica de Granada", I Congrés Internacional de Gravats Rupestres i Murals. Lleida, 1992.

BARRERA MATURANA, J. I. y CRESSIER, P. (en prensa): "Grabados parietales y rupestres de Almería: Un problema de cronología", I Congrés Internacional de Gravats Rupestres i Murals. Lleida, 1992.

BARRERA MATURANA, J. (:CRESSIER, P. y MOLINA MUÑOZ, J. A. (1999): "Garabatos de alarifes: Los graffiti de las galerías de desagüe de Madinat al-Zahra",Cuademos de Madinat al-Zahra. Vol.4. Córdoba, pp.39-8I .

BARRIS DURAN, J. ( I 983): "Insculturas rupestres en el Alto Ampurdán", Revista de Arqueología. Segunda Epoca, $N^{\circ} 25$, pp.23-27.

BAIIANA, A.;LAMBLIN, M-P.;MONTMESSIN,Y.;GISBERT, J.A., y VILLOTA, I ( 1984): Los graffiti medievales del Castell de Denia. Denia.

BERNAT, M.,GONZALEZ, E. y SERRA, J. (1986): "Els graffiti del campanar de la Seu de Mallorca", Estudis Baleárics. N 23, Vol. IV. Palma de Mallorca, pp.7-46.

BERNAT i ROCA, M. y SERRA i BARCELO, J. ( I 989): "L'aprenentatge d'un ofici:Graffiti arquitectónics a la Seu de Mallorca", Boletín de la Sociedad Arqueológica Luliana. N45, pp. I 77-2। 3.

BERTI,G. (1992): "Bacini ceramici e strutture architettoniche medievali: Considerazioni basate su una ricerca in Toscana", Coloquio Hispano-Italiano de Arqueología Medieval. Granada, pp. 133-172.

BERTI, G.,PASTOR, J. y ROSELLO-BORDOY, G. (1993): "Naves andalusíes en cerámicas mallorquinas", Trabajos del Museo de Palma. No 5 I. Palma de Mallorca.

BERTRAN i ROIGE, P. y FITE i LLEVOT, F. (1984-85): "Primera aproximació a la cerámica grisa i als "graffiti" del Castell d'Oroners (Ager,Lleida)", Acta Mediaevalia. $N^{\circ} 56$, pp. 387-418.

BEVIA, P.;PENALVER, R.;FERRE, P.;FERRANDIZ, J. Ma. y MARTIN, Ma. F. (1993): "Avance del Corpus de graffiti del término municipal de Alicante", LQNT. N I. Alicante, pp. I 85-90.

BURGOS JUAREZ, A.; LOPEZ SALMERON, J. y ROSALES ROMERO, J. (1989): "Excavaciones de urgencia en el solar situado en la Cruz de la Rauda del Albaicín, Granada", Anuario Arqueológico de Andalucía. T.I I I. Sevilla, pp. 196-198.

CAILLE, J. y HAINAUT,J. ( I 955): “La Qasba des Gnaoua”, Hesperis. I/2 Trimestre, pp. 27-65.

CAMPARDOU, J.y BASSET, H. (1921): "Graffiti de Chella", Hespéris, I, pp. 87-90.

CARA BARRIONUEVO, L. ( I 990): La Almería islámica y su Alcazaba. Almería.
CARA BARRIONUEVO, L. (1993): La civilización islámica, Historia de Almería 3. Almería.

CORTESVAZQUEZ, M. (1987): "Los petroglifos de Amtodi (Goulimine-Marruecos)", XVIII Congreso Nacional de Arqueología, Islas Canarias, 1985. Zaragoza, pp. II 5-15 I .

COSIN CORRAL, Y. y GARCIA APARICIO, C. (1998): "Alquerque, mancala y dados, juegos musulmanes en la ciudad de Vascos", Revista de Arqueología. Año XIX, N 20I. Madrid, pp.38-47.

CRESSIER, P. ( I 986a): "Graffiti cristianos sobre monumentos musulmanes de la Andalucía Oriental: Una forma de exorcismo popular", I Congreso de Arqueología Medieval Española, Huesca 1985. T.I. Zaragoza, pp.273-29 I .

CRESSIER,P. ( I 986b): "Dalías et son territoire: un groupe d'alquerías musulmanes de la Basse Alpujarra (Province d'Almería)", XII Congreso de la U.E.A.I., Málaga 1984. Madrid, pp.205-228.

CRESSIER, P. et allí. (1992): Estudios de arqueología medieval en Almería. Almería.

CRESSIER, P.;DELAIGUE, M.-C;; BARRERA MATURANA, J. I.; CARBONERO GAMUNDI, M. A.; EGEA GONZALEZ, J. J. y OSUNA VARGAS, Ma. M. (I99 I ): "Poblamiento y cultura material en un territorio elemental medieval de la Sierra de los Filabres. El Valle de Senés (Almería). Campaña 199 I ", Anuario Arqueológico de Andalucía. T.I I. Sevilla, pp.36-5 I.

CRESSIER, P.,RIERA FRAU, Ma. M. y ROSELLO BORDOY, G. (1992): "La cerámica tardo almohade y los orígenes de la cerámica nasri", Quaderns de Ca La Gran Cristiana II. Palma de Mallorca.

DE BUNES IBARRA, M. A. y MARTINEZ LILLO, S. (I993): "La navegación mediterránea en Epoca Medieval", II Curso de Arqueología Subacuático, Univ. Autónoma de Madrid., Varia 2. Madrid, pp.83- 119.

DE CARLOS, A. ( I 973): "El arte militar en las Cantigas de El Escorial", Reales Sitios. Rev. del Patrimonio nacional. Año X, No 35. Madrid, pp.33-40.

DE SANTIAGO SIMON, E. (1974): "Restos de un zócalo morisco en una casa del Albaicin", Miscelánea de Estudios Arabes y Hebraicos. Vol.XXIII, Fasc. I ${ }^{\circ}$. Granada, pp. 12 I $-123$.

DEL MARMOL CARVAJAL, L. ( 600 ): Historia de la rebelión y castigo de los moriscos del Reino de Granada. Málaga (reed. I 99 । ).

DIAZ GARCIA, A. y LIROLA DELGADO, J. A. ( I 989): "Nuevas aportaciones al estudio de los cementerios islámicos en la Granada nazarî", Rev. del Centro de Est. Históricos de Granada y su Reino. Segunda Epoca, No 3. Granada, pp. I 03- I 26.

DIEZ-CORONEL Y MONTULL, L (1986-87): "Grabados Rupestres Prehistóricos en el Pirineo Leridano y Andorrano del tipo "Roca de les Bruixes I", I Congreso Internacional de Arte Rupestre. T.VII-VI I I. Caspe (Zaragoza), pp. 235-264.

ETTINGHAUSEN,R. (1954): "Notes on the lusterware of Spain", Ars Orientalis. Volt, pp. I33- 156. 
FERNANDEZ IBAÑEZ, C.;FERNANDEZ SANDINO, J:SAIZ QUEVEDO, M. L., y MARQUEZ ALVAREZ, M. J. (1987): "Informe preliminar acerca de los grabados bajomedievales del castillo de Jubera (La Rioja) y su entorno histórico-artístico", II Congreso de Arqueología Medieval Española. T.III. Madrid, pp. 405-4I3.

FLORES ESCOBOSA, I. y MUÑOZ MARTIN, Ma. M. (1993): Vivir en al-Andalus. Almería.

FORTEA, J. ( 197I): "Grabados rupestres esquemáticos en la provincia de Jaén", Zephyrus. Vol.XXI-XXII. Salamanca, pp. 139-156.

GALLEGO Y BURIN, A. (1982): Granada. Guía Artística e Histórica de la Ciudad. Granada

GARCIA GRANADOS, J. A.; GIRON IRUESTE, F. y SALVATIERRA CUENCA, V. (1989): El Maristán de Granada. Un Hospital Islámico. Granada.

GARCÍA GRANADOS, J. A. y SALVATIERRA CUENCA, V. (198I): "El Maristán de Granada. Entre la fantasía romántica y la realidad arqueológica", Revista de Arqueología. N 42. Madrid, pp. 16-25.

GARCIA SANCHEZ, M. y SPAHNI, J.C. (1958):"'Grabados rupestres esquemáticos de época eneolítica en Baños de Alicún (Granada)", Archivo de Prehistoria Levantina. T.VII. Valencia, pp. 121-136.

GARRIDO GARRIDO, M. y GARCIA GRANADOS, J. A. ( 1 987): "Introducción al 'estudio de la cerámica estampillada andalusí en Granada", II Congreso de Arqueología Medieval Española. T.Il. Madrid, pp. 677-687.

GATTEFOSSE, J. (1933): "Graphismes en fer-a-cheval du Dadés", Bulletín de la Société de Préhistoire du Maroc. N 7 ( I), Casablanca, pp. 32-36.

GOMEZ MORENO, M. (I888): Medina Elvira. Granada (reed. 1982).

GOMEZ MORENO, M. ( 1892 ): Guía de Granada. Granada (reed. 1982)

GOMEZ-MORENO, M. (1970): "Pinturas de moros en el Partal (Alhambra)", Cuadernos de la Alhambra. Vol.6. Granada, pp. I55-I 64.

GONZALEZ GONZALO, E. (1986):" Graffiti de la Torre de Sant Joan de la Llotja", Bolletí del Institut d'Estudis Baleárica. $N^{\circ}$ 23, Año 4. Palma de Mallorca, pp. 47-56.

GONZALEZ GONZALO, E. (1990): "Los graffiti históri$\cos$ y las pinturas murales populares. Primer paso para su protección y salvaguarda en el ámbito del patrimonio cultural", Bolletín de la Sociedad Arqueológica Luliana. № 46. Palma de Mallorca, pp. 27l-274.

GONZALEZ GONZALO, E. (1992): “Tipos náuticos en los graffiti mallorquines (siglos XIV-XVI)", VIII Colloque International de Glyptographie d'Hoepertingen (Euregio).

GONZALEZ GONZALO, E. y PASTOR QUIJADA, X. (1993): "La arquitectura naval de los graffiti medievales mallorquines", IV Congreso de Arqueología Medieval Española. T.II I. Alicante, pp. I035- 1047.
HERBER, J. ( 1927): "La main de Fathma", Hespéris. Vol. VII, PP. 209-219.

HERBER, J. y DAVID, X. (1933): "A propos des dalles gravées au Cap Cantin", Bulletín de la Société de Préhistoire du Maroc. No 7 ( I ), Casablanca, pp. 27-31.

IZQUIERDO BENITO, R. ( 1994): Ciudad hispanomusulmana "Vascos" Navalmoralejo (Toledo). Campañas 1983-1988. Toledo-Madrid.

JANER, F. ( I 874): "Los libros del ajedrez, de los dados y de las tablas. Estudio artístico-arqueológico", Museo Español de Antigüedades. Vol. I II. Madrid, pp. 225-255.

LIAÑO MARTINEZ, E.; RAMON LOPEZ, Ma. J. y VILLARO GUMPERT, Ma. J. (1969): "El Castillo de Monzón", Castillos de España. Revista de la Asoc. Esp. Amigos de los Castillos, Año XVI, n 66, pp. 28I-309.

LIROLA DELGADO, J. ( I 993): El poder naval de Al-Andalus en lo época del Califato Omeya. Granada.

LOPEZ CUERVO, S. ( 1983): Medina al-Zahra, ingeniería y formas. Madrid.

LLUBIA,L.M (1973): Cerámica Medieval Española. Barcelona.

MALPICA CUELLO, A. (1982-83): "La villa de Motril y la repoblación de la Costa de Granada (1489-15I0)", Cuadernos de Estudios Medievales, Vol. X-XI. Granada, pp. 169-206.

MALPICA CUELLO, A. (1996): Poblamiento y Castillos en Granada. Madrid.

MARTIN GARCÍA, M. (1985-87): "La muralla exterior del Albayzín o "Cerca de Don Gonzalo".Estudio histórico y descriptivo", Cuadernos de Estudios Medievales. Vol.XIVXV. Granada, pp. 177-210.

MARTINEZ GARCIA, J.( I 995): "Grabados Prehistóricos, grabados históricos: Reflexiones sobre un debate a superar", Revista de Arqueología. Año XVI, No 172. Madrid, pp. 14-23.

MASY GIL, L. (1969): "Hisnargüela o Hasnargüela”, Castillos de España. Revista de la Asoc. Esp. de Amigos de los Castillos. Año XVI, N 65. Madrid, pp. 173-180.

MEDINA FLOREZ,V. J. y MANZANO MORENO, E. (1995): Técnica y metodología en la restauración de pinturas murales nazaríes. Granada.

MORENO ONORATO, Ma. A. y MERIDA GONZALEZ, V. (1990): "Intervención arqueológica de urgencia en el solar situado junto a la Puerta de Fajalauza del Albaicin (Granada)", Anuario Arqueológico de Andalucia 1987. T. III. Sevilla, pp. 223-224.

NAVARRO PALAZON, J. (1986): La cerámica islámica en Murcia. I. Catálogo. Murcia.

NAVARRO POVEDA, C. (1993): Graffitis y signos lapidarios del Castillo de la Mola (Novelda) y del Castillo de Petrer, Petrer (Alicante). Alicante.

OCAÑA JIMENEZ, M. (1986): "Arquitectos y mano de obra en la construcción de la gran mezquita de Occidente", Cuadernos de la Alhambra. Vol. 22. Granada, pp. 55-85. 
PASCUAL, J. y MARTI, J. (1986): La cerámica verde-manganeso bajomedieval valenciana, Arqueología 5. Valencia.

PAVON MALDONADO, B. (1972): "La loza doméstica de Madinat al-Zahra", Al-Andalus. Vol. XXXVII. Madrid, pp. |9|-227.

PAVON MALDONADO, B. (1980): "Miscelánea de Arte y Arqueología hispanomusulmana I" Al-Qantara. Vol.I. Madrid, pp. 385-4I7.

PAVON MALDONADO, B. (1985): "Arte, símbolo y emblemas en la España musulmana", Al-Qantara. Vol.VI. Madrid, pp. 397-450.

PAVON MALDONADO, B. (1996): España y Túnez: Arte y Arqueología Islámica. Madrid.

POSAC MON, C. (1980-8I): "Parangón entre las cerámicas medievales de Ceuta y las de Málaga", Mainake. Vol. | |- | | I. Málaga.

RETUERCE VELASCO, M. y ZOZAYA, J. (1986): "Variantes geográficas de la cerámica omeya andalusí: los temas decorativos", III Congresso Internazional sulla Ceramica Medievale nl Mediterraneo Occidentale (Siena 1984). Firenze, pp. 64-128.

RODRIGO MARHUENDA, L. Y CALANCHA DE PASSOS, J. (1990): “Crónica de Conservación y Restauración: Conservación y restauración de las pinturas murales de la Puerta de Armas y Torre de los Picos", Cuadernos de la Alhambra. Vol.26. Granada, pp. 349-370.

RODRIGUEZ, A. (1987-88): "Corpus des gravures rupestres libyco-berberes de Marrakech", Bulletin d'Archéologie Marocaine. T.XVII, pp. 89- I80.

RODRIGUEZ LOPEZ, J. MI'. y CARA BARRIONUEVO, L. (1990): "El fenómeno místico-religioso rural en los últimos siglos del islam andalusí: introducción al estudio arqueológico de las rábitas alpujarreñas", Almería entre culturas. Siglos XIII-XVI. Coloquio de Historia. T.I. Almería, pp. 227-254.

ROSSELLO CREMADES, N.; ROSSER LIMIÑANA, P. y QUILES CALERO, I. (1993): "Estudio de una vivienda almohade", IV Congreso de Arqueología Medieval Española. T.II. Alicante, pp. 123-129.

RUIZ TORRES, S. y PADIAL PEREZ, J. (200 I): "La muralla nazarí del Albaycín: un ejemplo de los procedimientos y técnicas constructivas empleadas en la Edad Media", CVDAS, 2, pp. |3|-|53.
SECO DE LUCENA PAREDES, L (1965): "El hayib Ridwan, la Madraza de Granada y las murallas del Albayzín", Al-Andalus. Vol.XXI. Madrid, pp. 286-296.

TORRES BALBAS, L (1944): "Las mazmorras de la Alhambra", Al-Andalus. Vol.IX. Madrid, pp. 198-218 (reed. en Torres Balbás, 1981, Vol.2, pp. 310-332).

TORRES BALBAS, L. (I 948a): "Dar Al-Arusa y las ruinas de palacios y albercas granadinos situados por encima del Generalife", Al-Andalus. Vol. XIII. Madrid, pp. I 85-203 (reed en Torres Balbás, I981 ,Vol. 4, pp. 99-II9).

TORRES BALBAS, L. (1948b): "Rábitas hispanomusulmanas", Al-Andalus. Vol.XI I I. Madrid, pp. 475-49I (reed. en Torres Balbás, 1981,Vol.4, pp. 157-174).

TORRES, C.; PASSINHAS DA PALMA, M.; REGO, M. y MACIAS, S. (1996): "Técnicas e utensilios de conservacao dos alimentos na Mértola islámica", Arqueología Medieval. Vol.4. Campo Arqueológico de Mértola, pp. 203-217.

VELAZQUEZ BOSCO, R. (1912): Arte del Califato de Córdoba. Medina Azzahra y Alamiriya, Madrid.

VILASECA DE PALLEJA, L. (1970): "Grabados rupestres de los términos municipales de la Riera y Prades (Tarragona)", XI Congreso Nacional de Arqueología. 1986. Mérida, pp. 292-297.

VILCHEZ VILCHEZ, C. (1988): "Descubrimiento y excavación de la Puerta de San Lorenzo de la muralla nazarí en el Albayzín de Granada", Cuadernos de Arte de la Universidad de Granada. Granada, pp. 217-224.

VILCHEZ VILCHEZ, C. (1990): "Excavación de urgencia en la muralla nazarí (siglo XIV) de Granada. SeptiembreOctubre de 1986", Anuario Arqueológico de Andalucia 1987. T.IIl. Sevilla, pp. 245-252.

VILLA-REAL, ECO. de P. ( I888): El libro de las tradiciones de Granada. Granada (reed.1997)

V.V.A.A..( 198I): "Los grafitos de Castellfollit de Riubregós. Primeras aportaciones", Quaderns d'estudis medievals. Año II, No 5, pp. 278-3I0.

V.V.A.A. (199| ): El aprovechamiento del sistema de saneamiento en Madinat al-Zahra', Cuadernos de Intervención en el Patrimonio Histórico. № 6. Córdoba.

V.V.A.A. (1995): Al-Andalus y el Mediterráneo. Madrid.

ZAPATA SANCHEZ, A.; ANIBAL GONZALEZ, C. y PACHON ROMERO, J. A. (1995): "El grabado rupestre prehistórico en Granada. Hallazgos inéditos de Alfacar", Revista de Arqueología. N 169. Madrid, pp. 10- 15. 


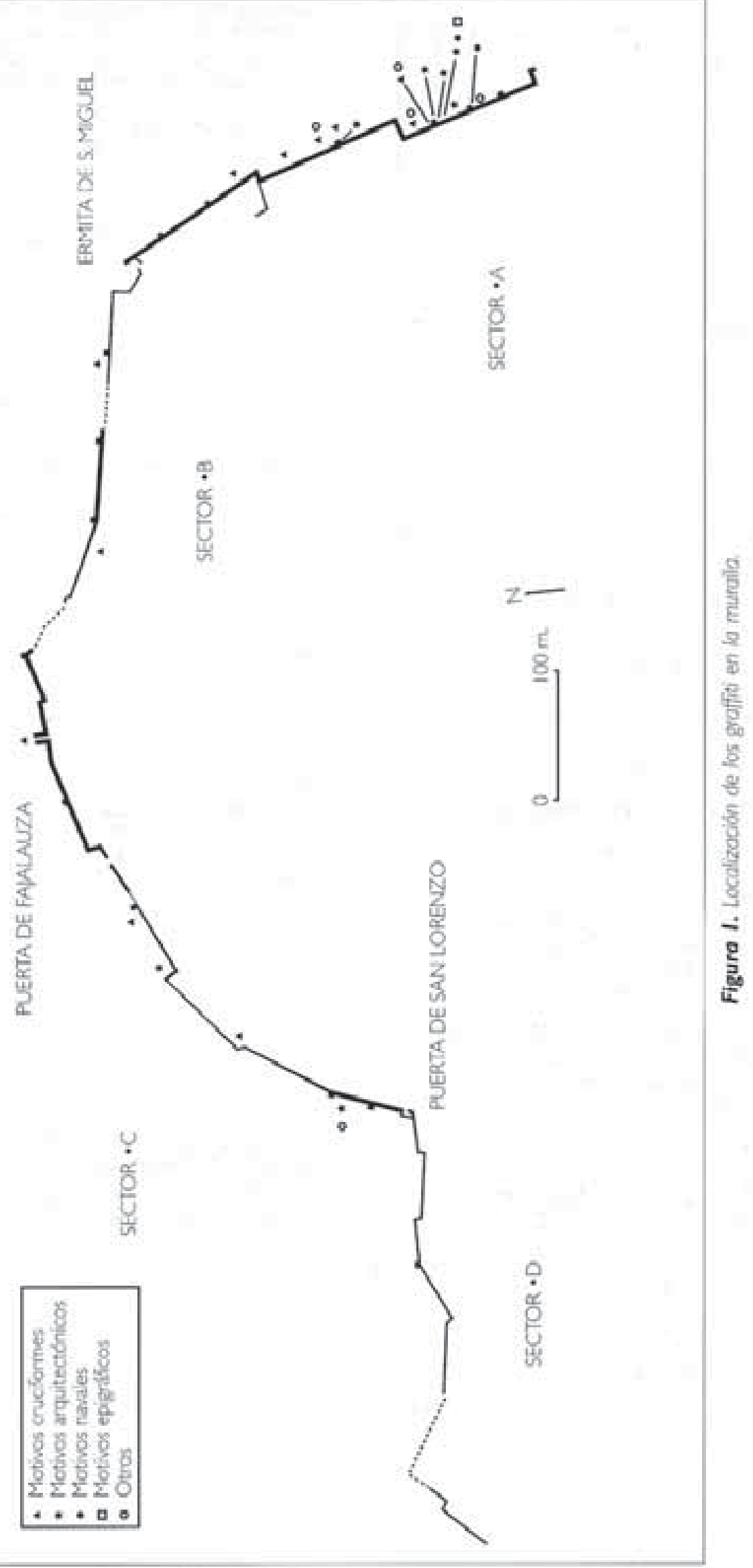




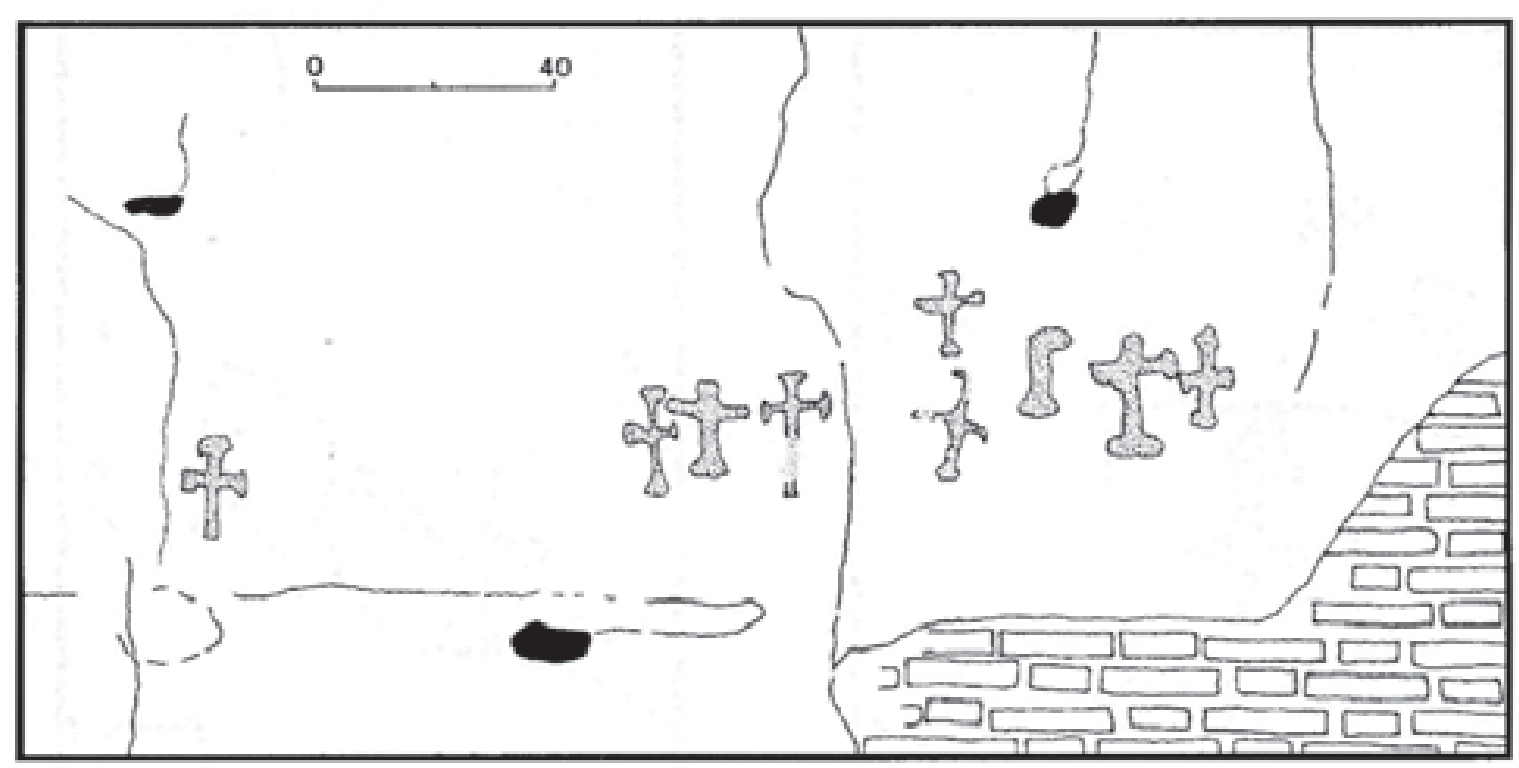

Figura 2. Cruces latinas, algunas potenzadas.

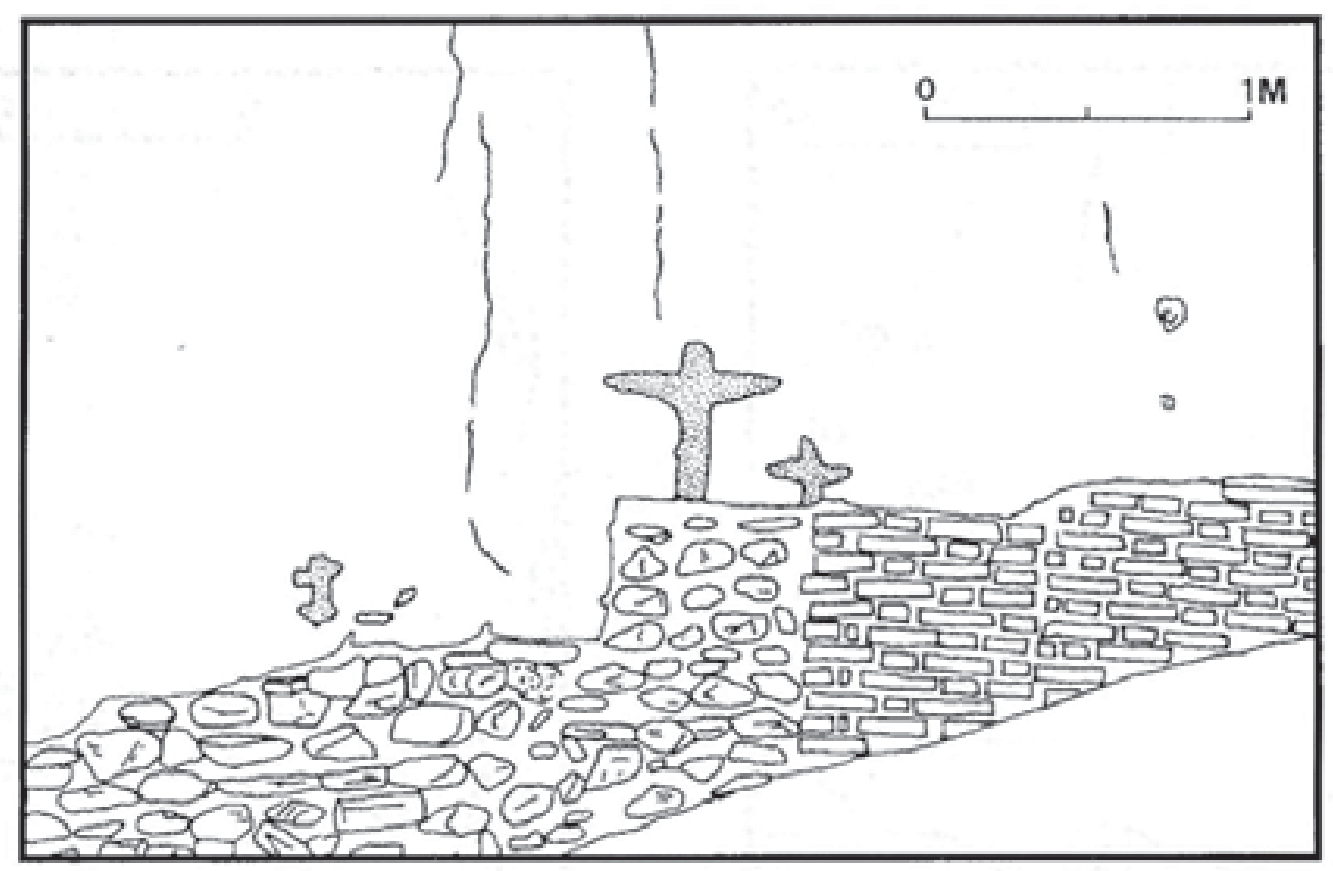

Figura 3. Cuces latinas. 


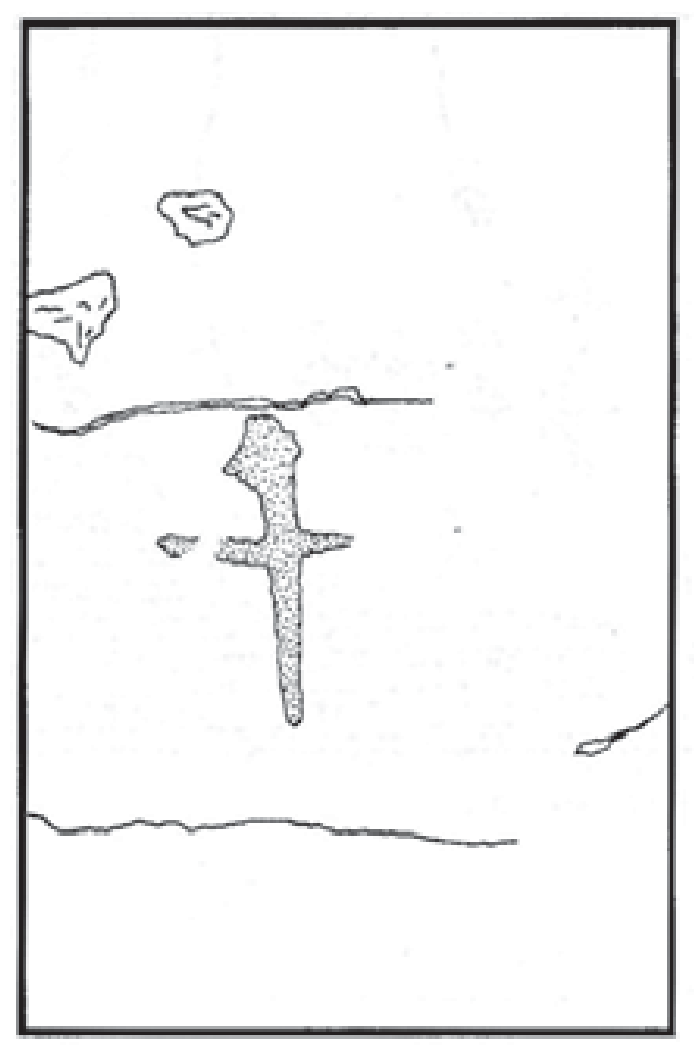

Figura 4: Cruz latina.

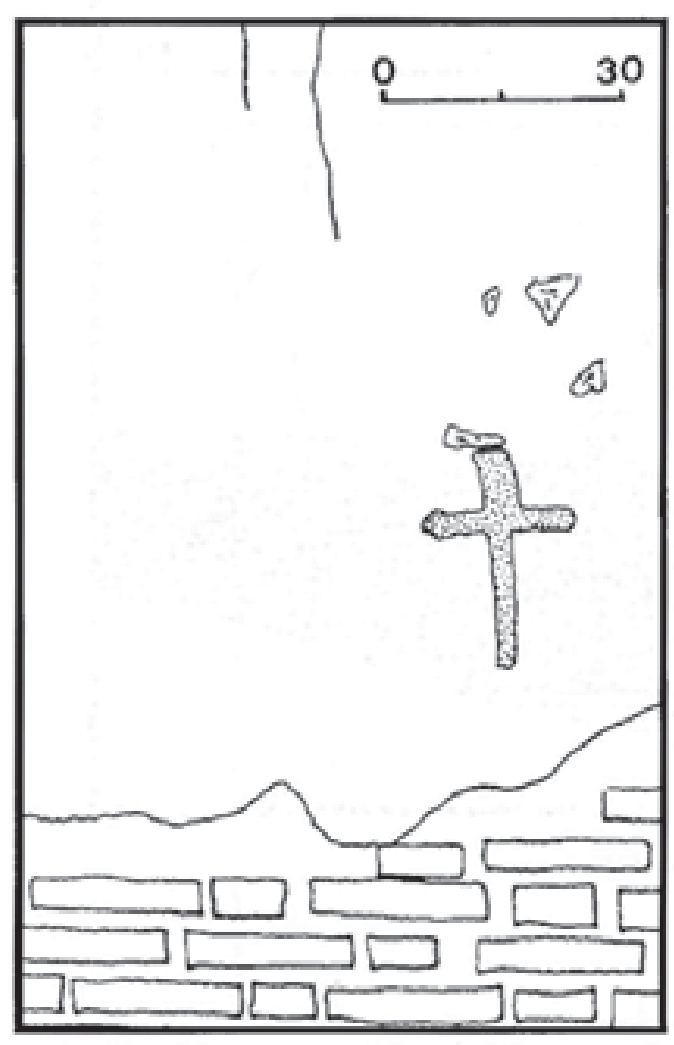

Figura 6. Cruz latina.

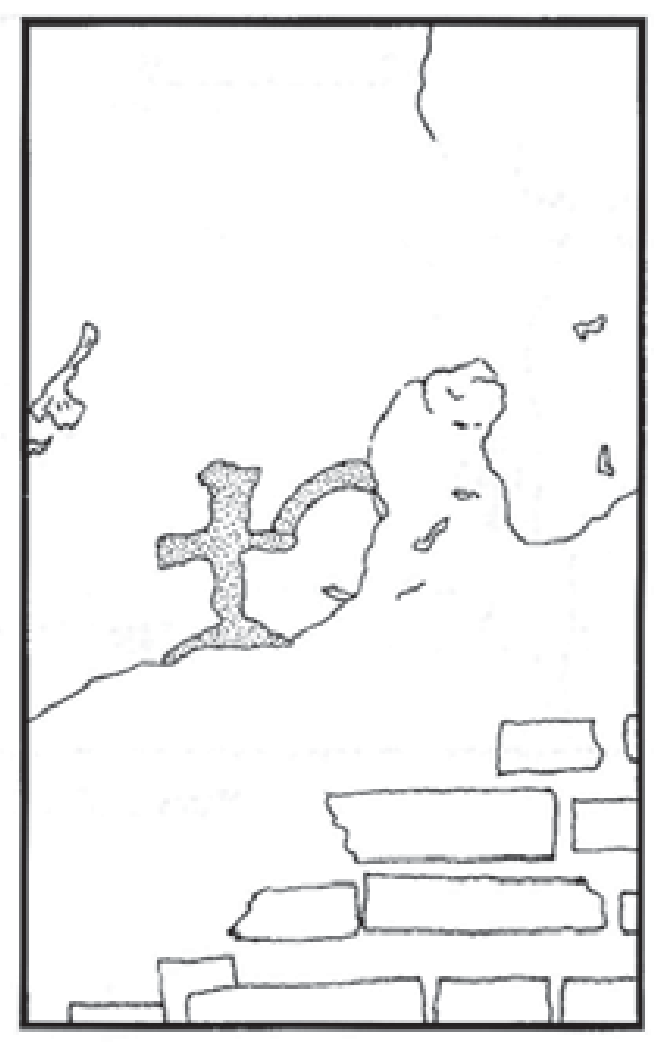

Figura 5. Cruz latina.

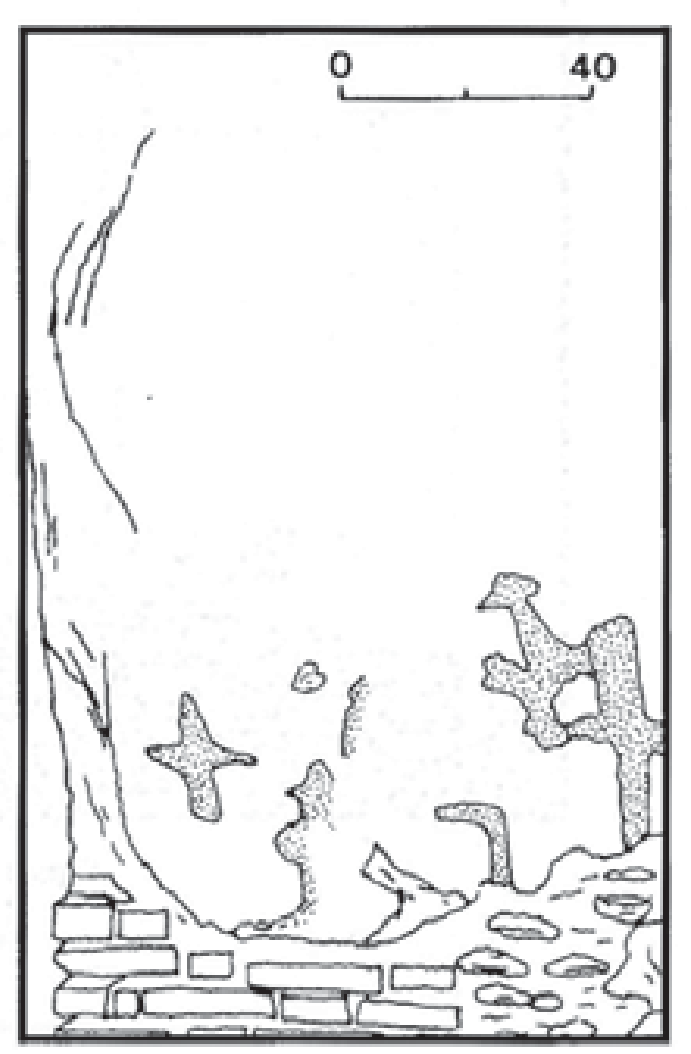

Figura 7. Cruces latinos. 


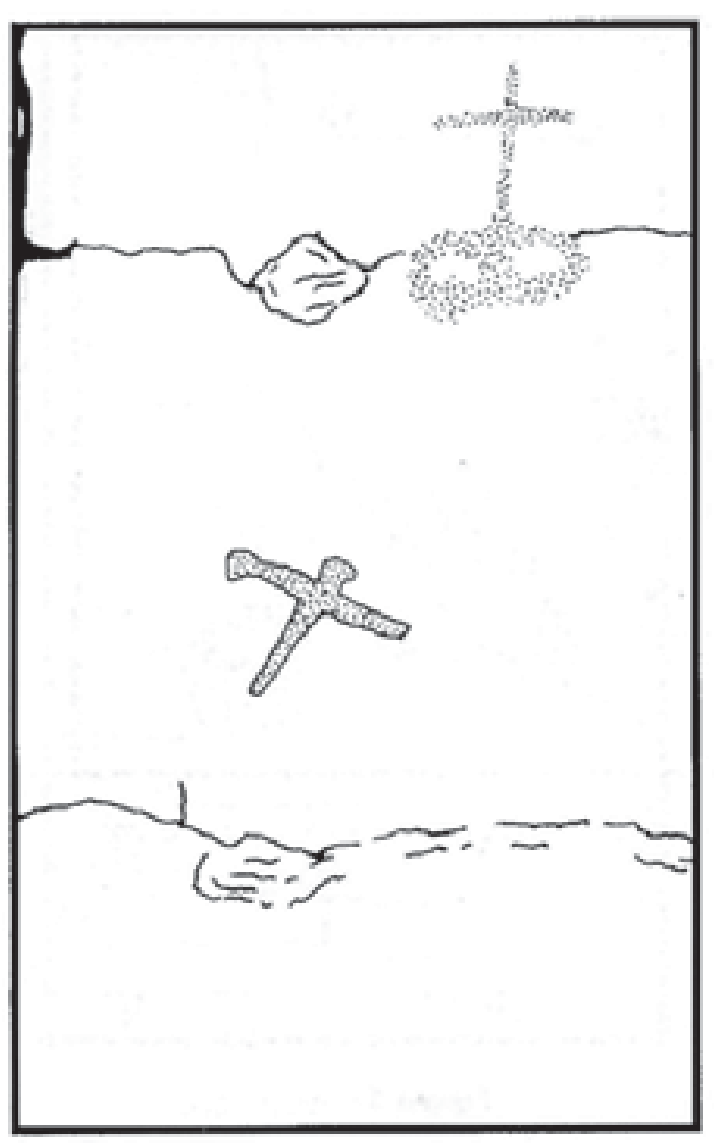

Figura 8. Cruz latina y otra posible que noce de dos círculos.

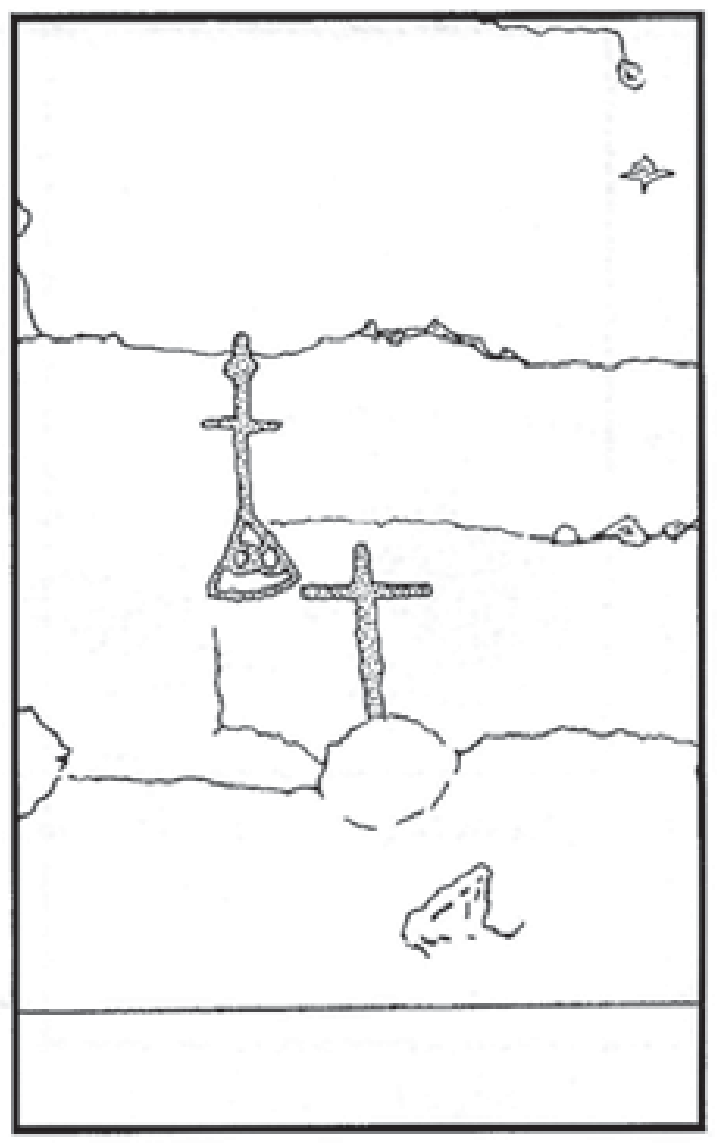

Figura 10. Cnuces latinas, una de ellas noce de peana triangular o cruz de calvario.

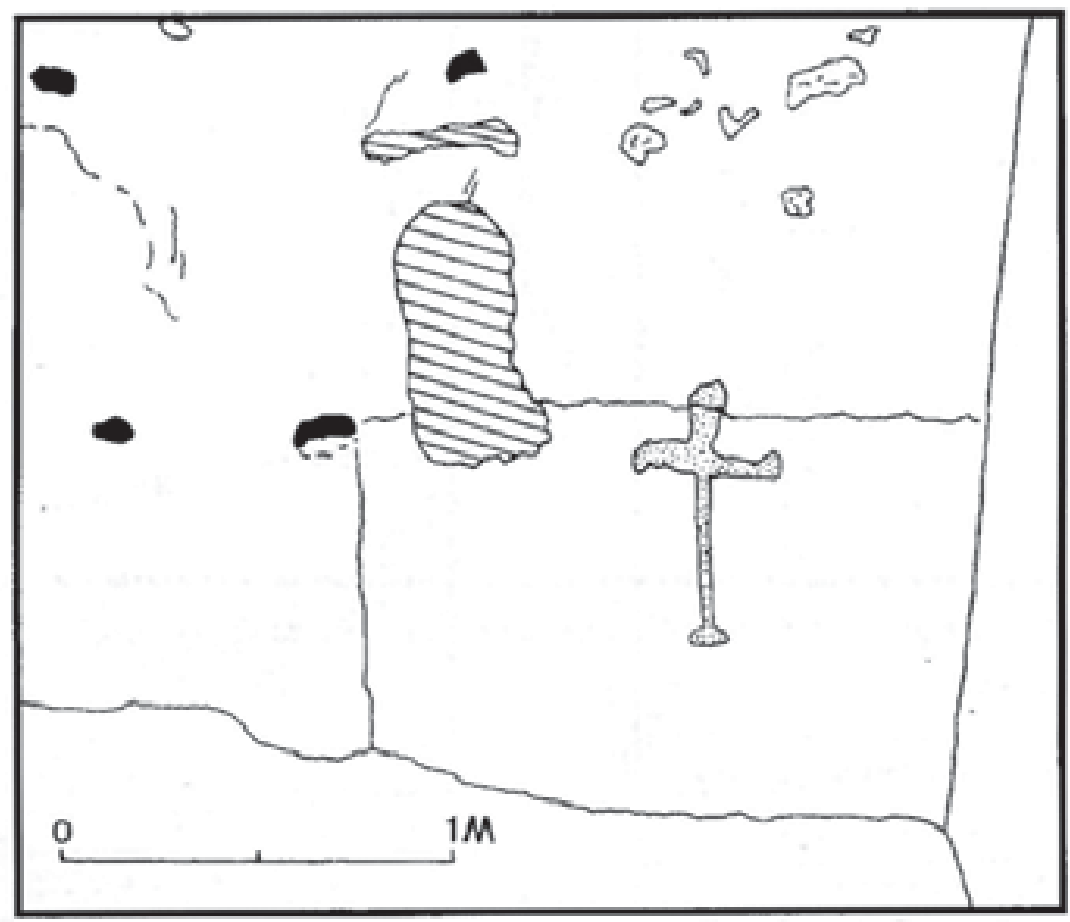

Figura 9. Cnzz lotina. 


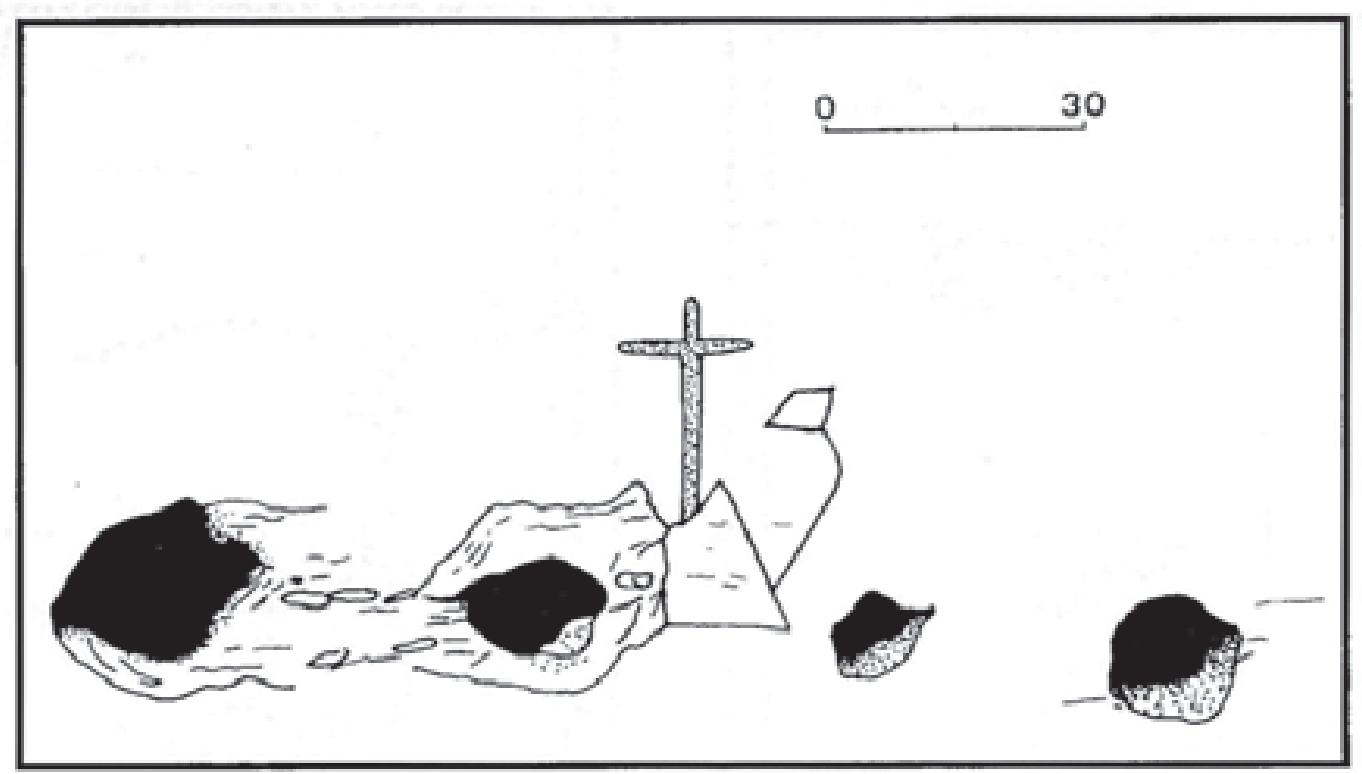

Figura 11. Cnuz sobre peano triangular o cnzz de calvario (interior de lo Puerto de Fojalcuzo).

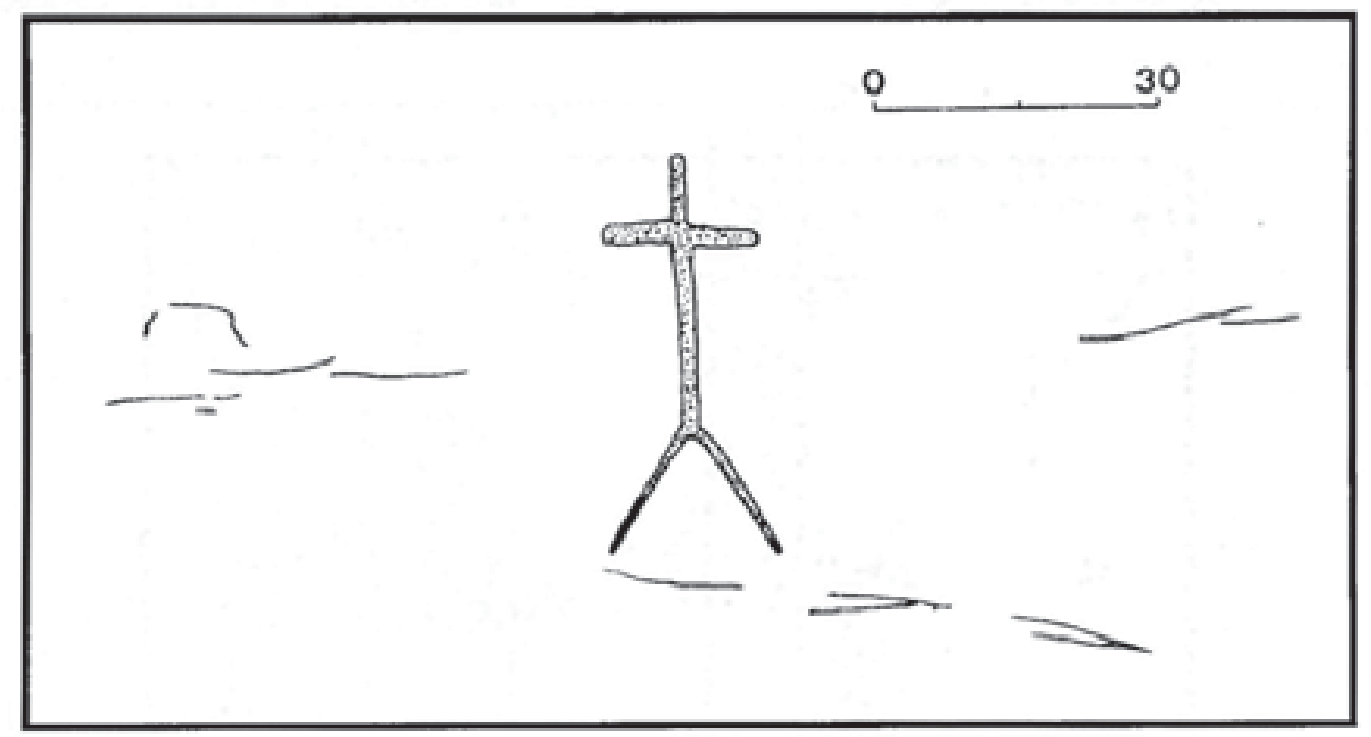

Figura 12. Cruz sobre ángulo (interior de la Puerta de Fajalouza). 


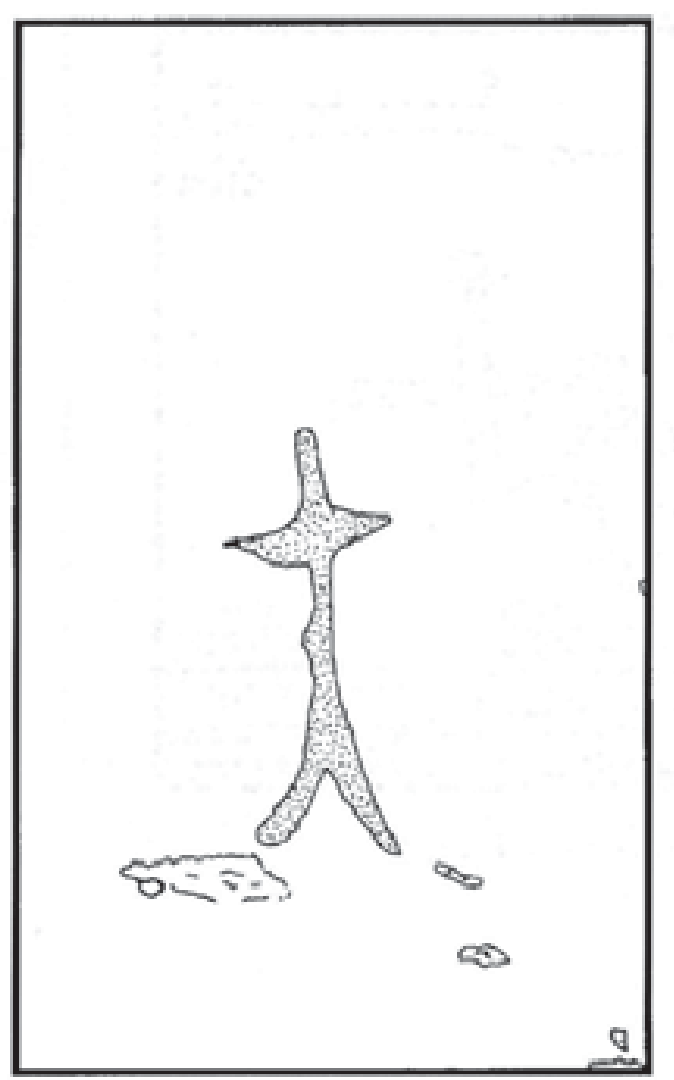

Figura 13. Cruz sobre ángulo.

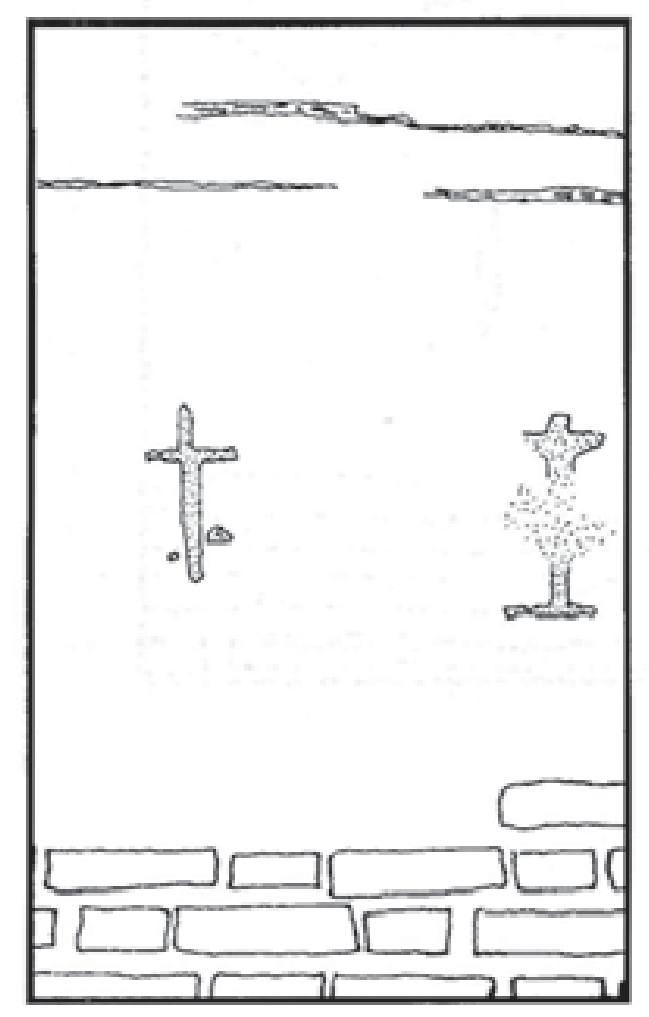

Figura 15. Cruz latina y de Lorena.

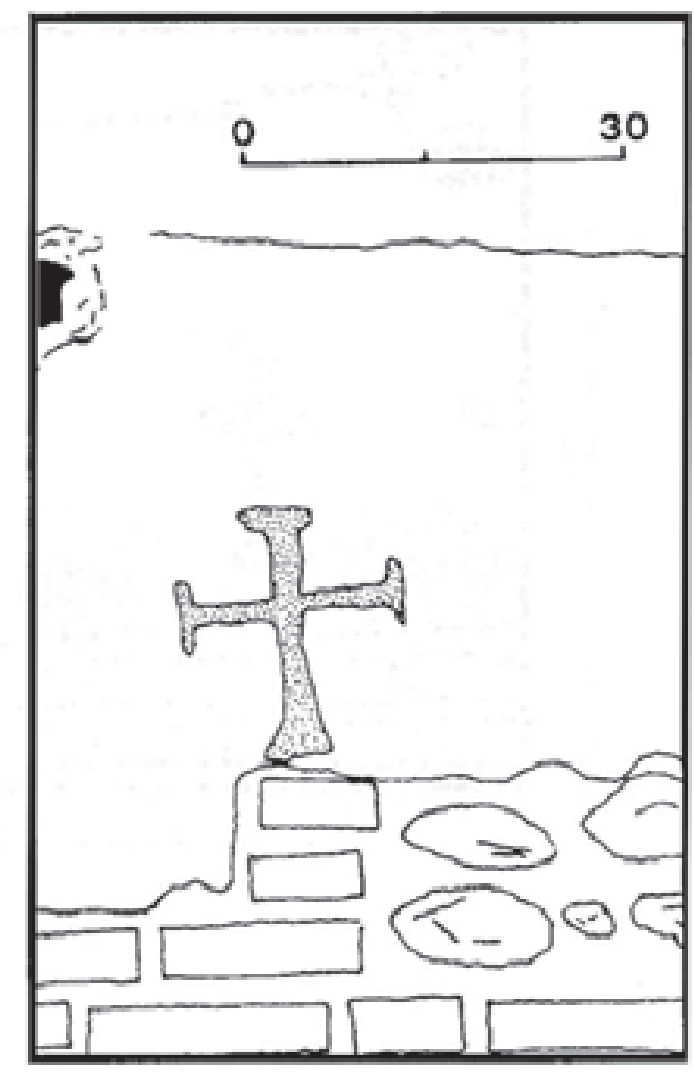

Figura 14. Cruz potenzoda.

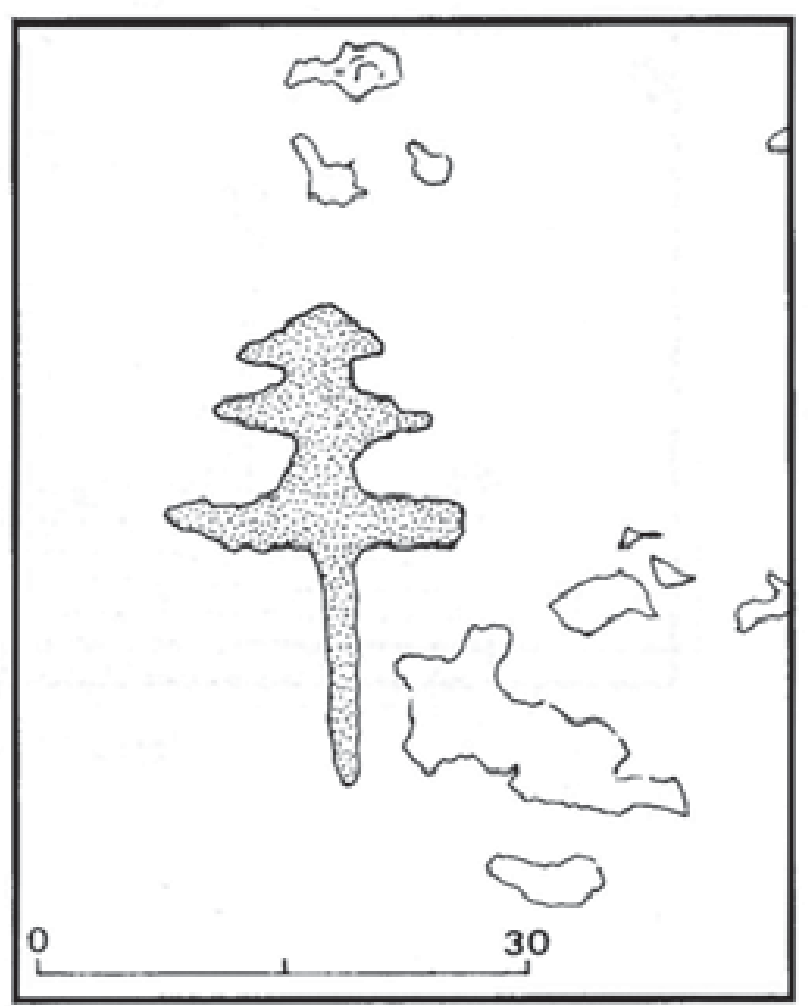

Figura 16. Cruz popal o potriorcal. 


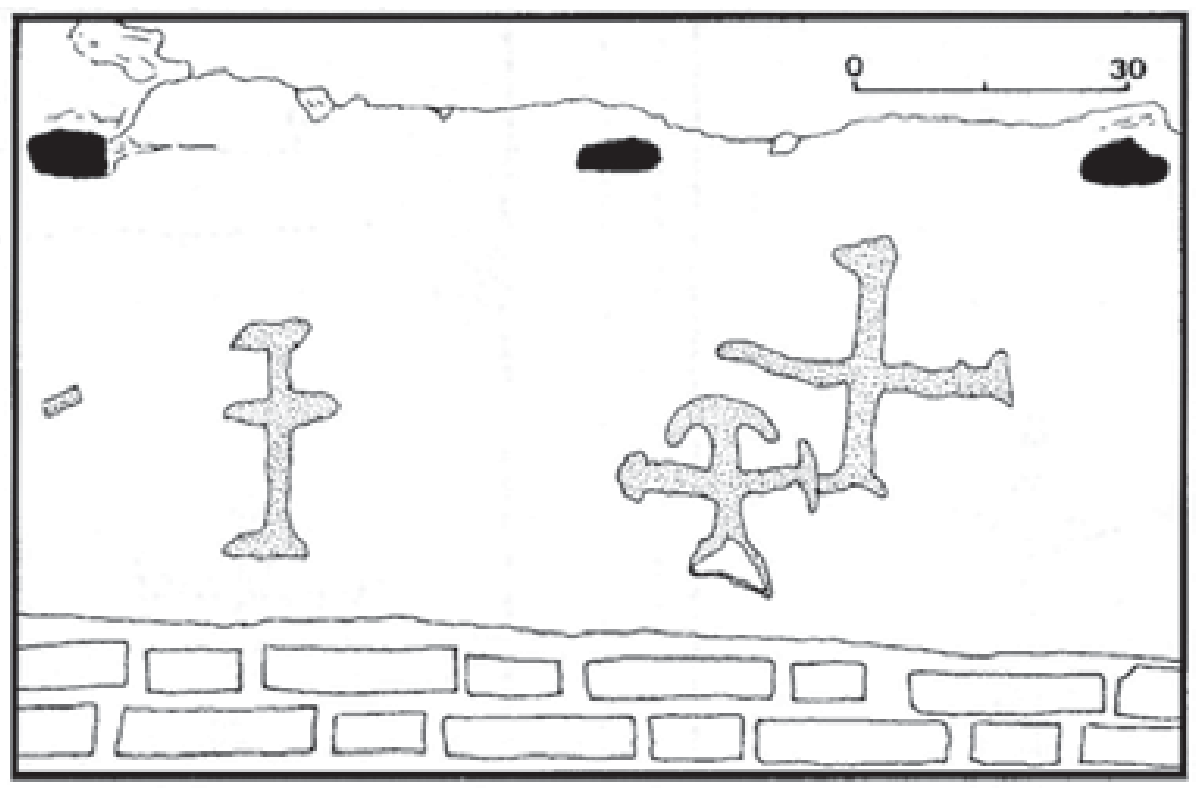

Figura 17. Cnuces potenzadas, de calvario y de Lorena.

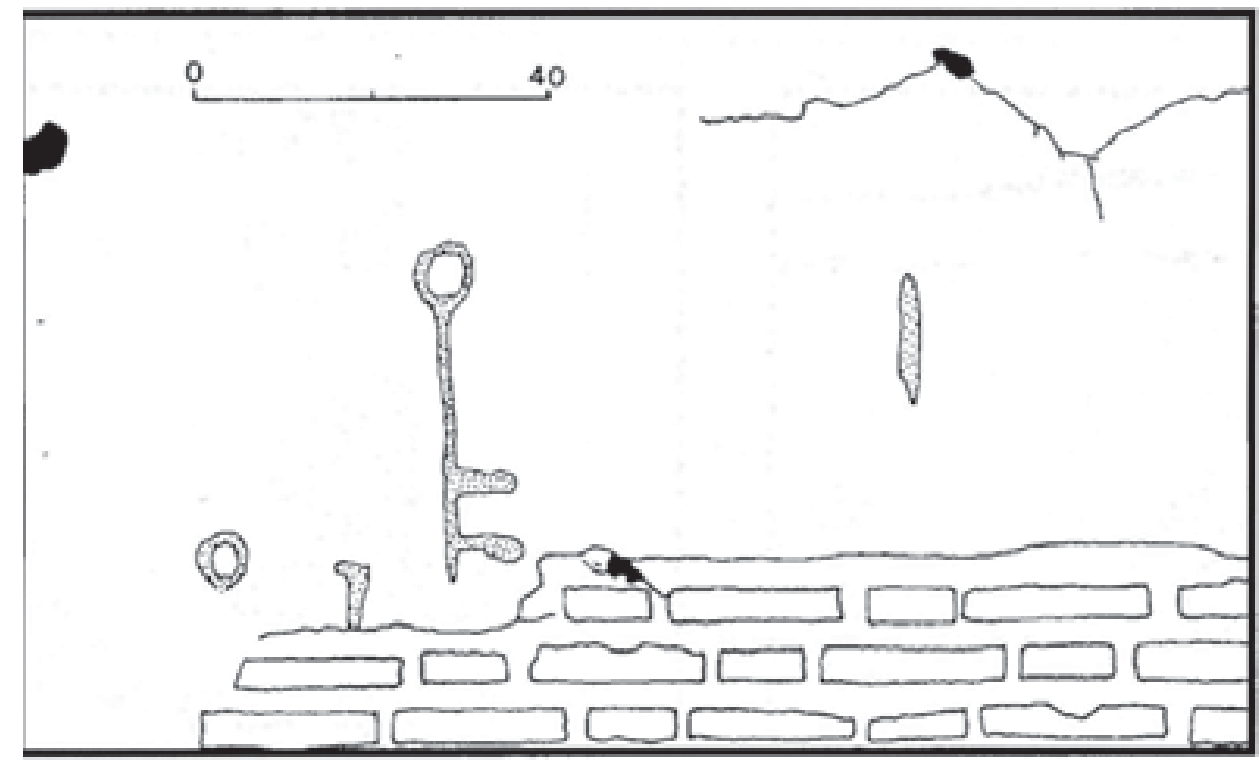

Figura 18. Love. 


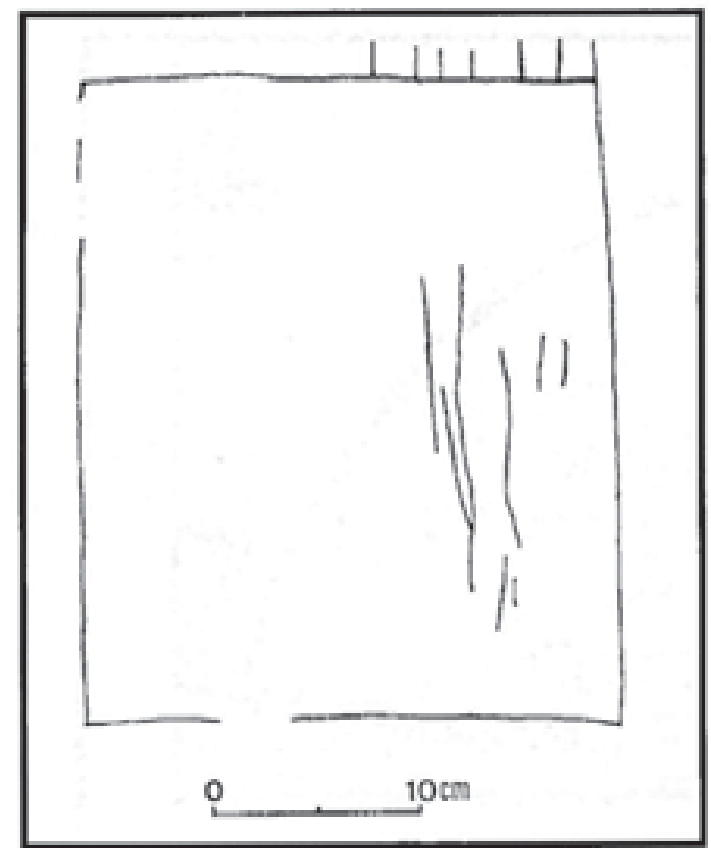

Figura 19. Castillo $n^{\circ} 1$.

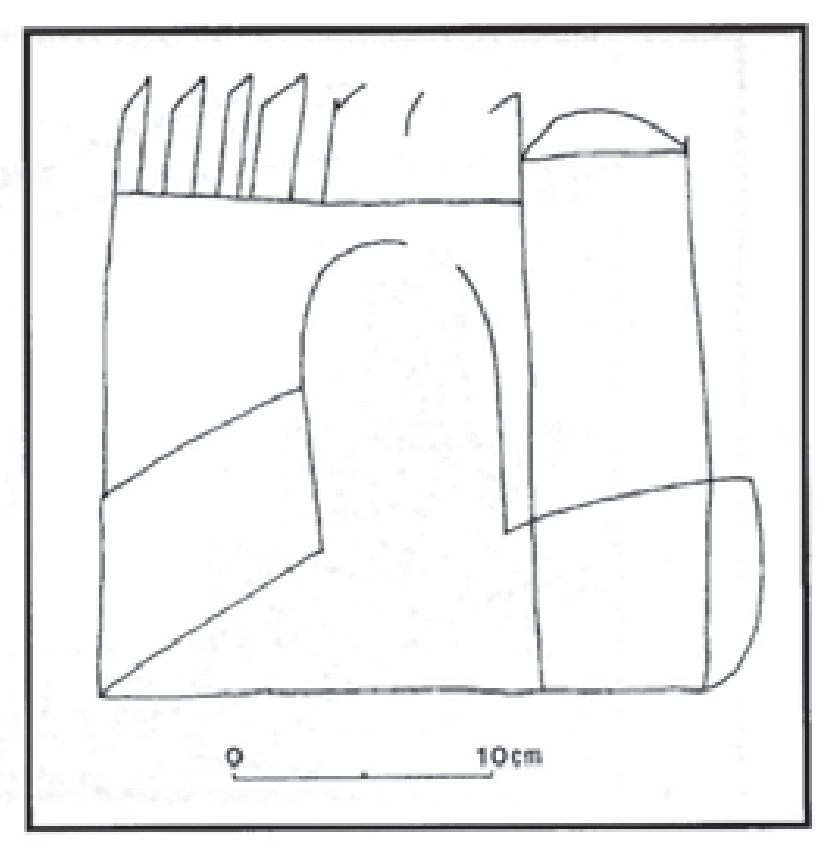

Figura 20. Costillo $n^{\circ} 2$.
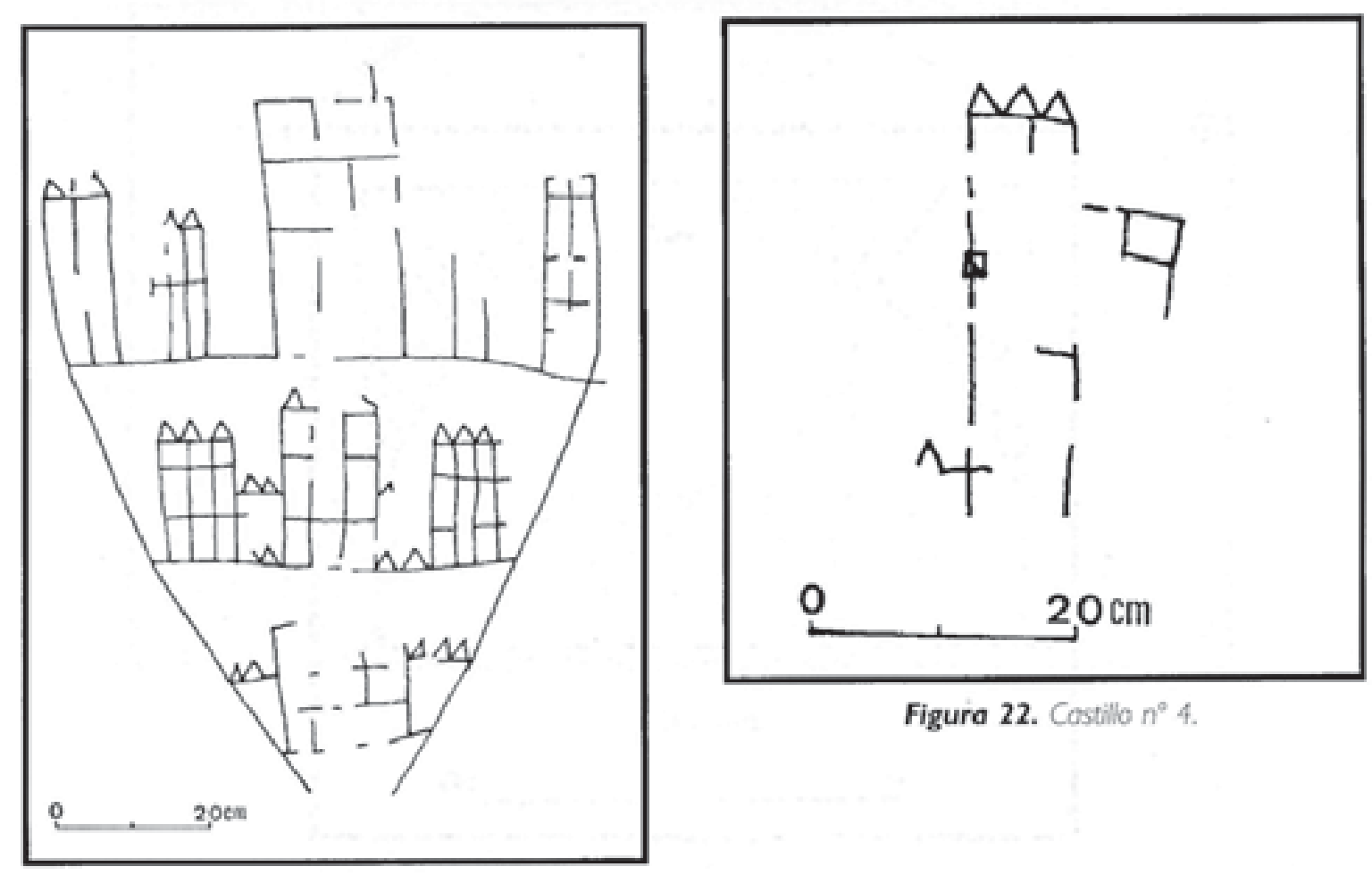

Figura 22. Costillo $n^{\circ} 4$.

Figura 21. Costillo n० 3; Escudo con costillos. 


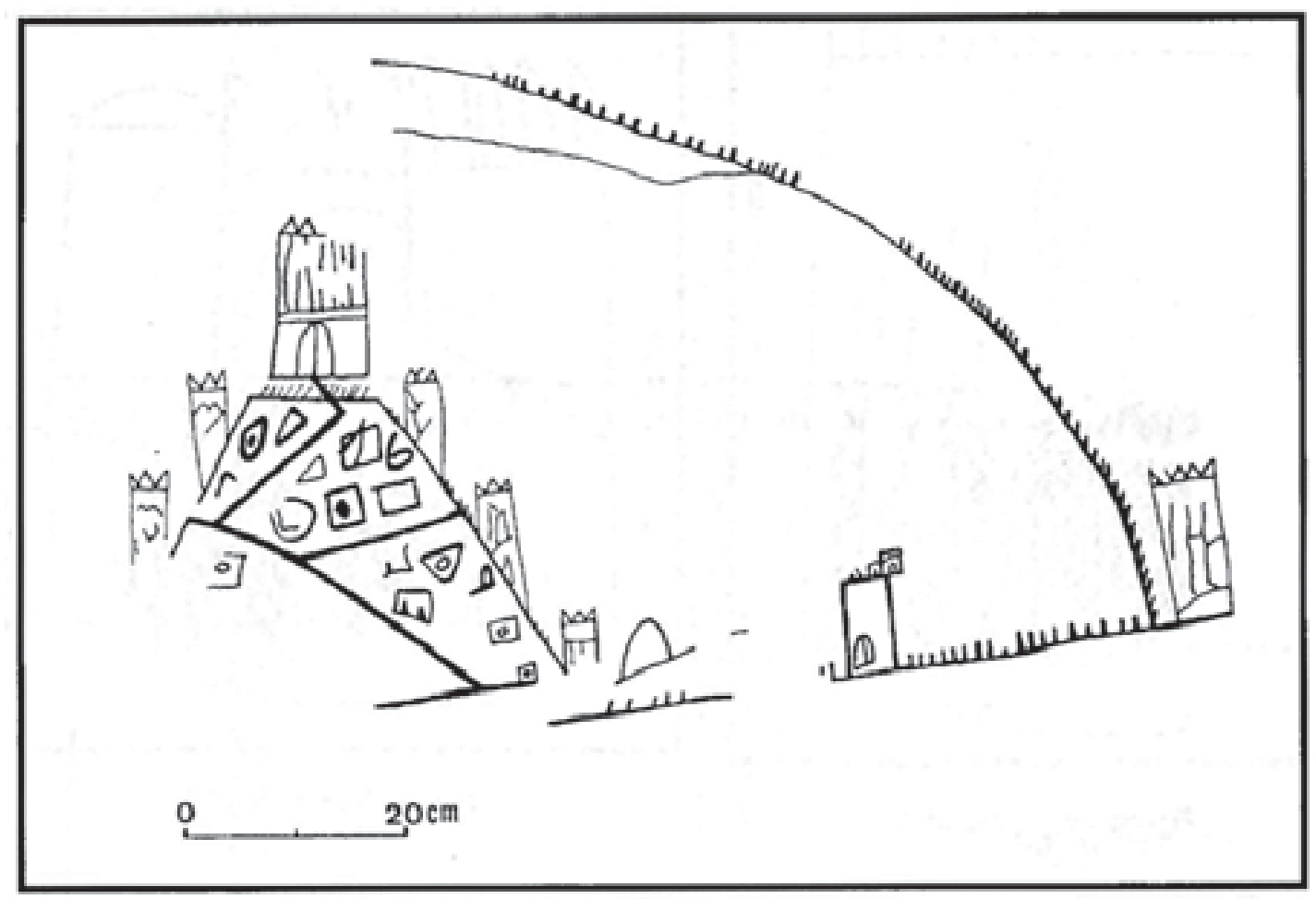

Figura 23. Castillo $n^{\circ}$ 5: Recinto fortificoda.

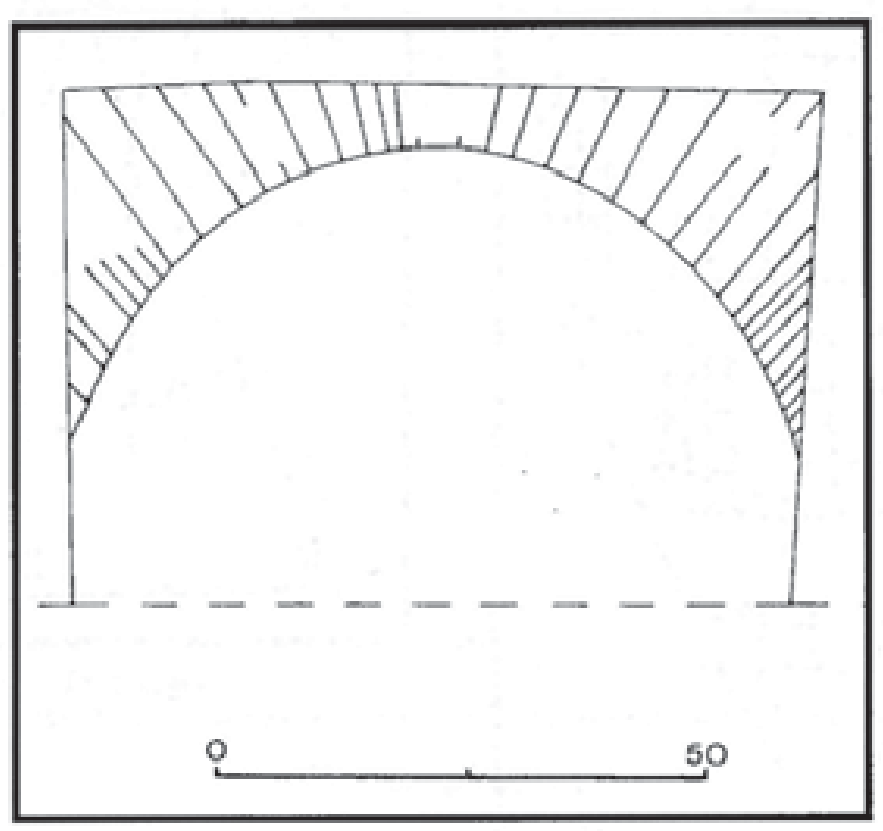

Figura 24. Arco de herrodura (ver nota 6). 


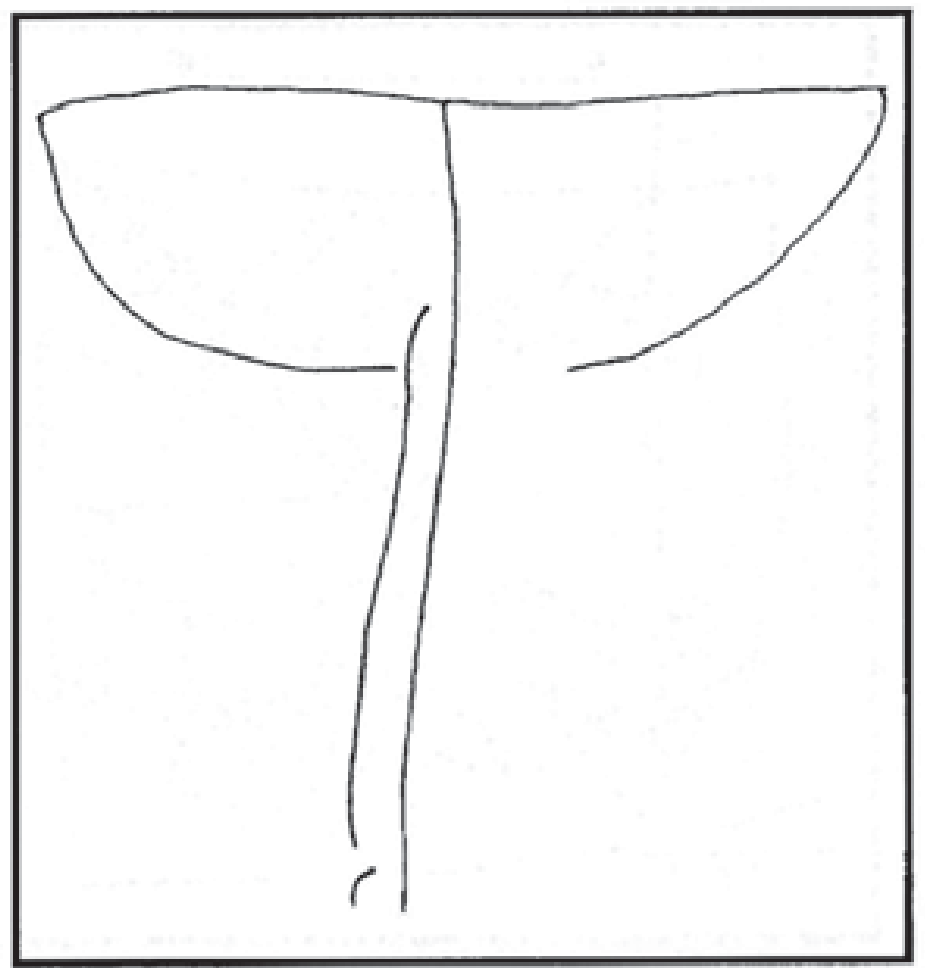

Figura 25. Bollesta.

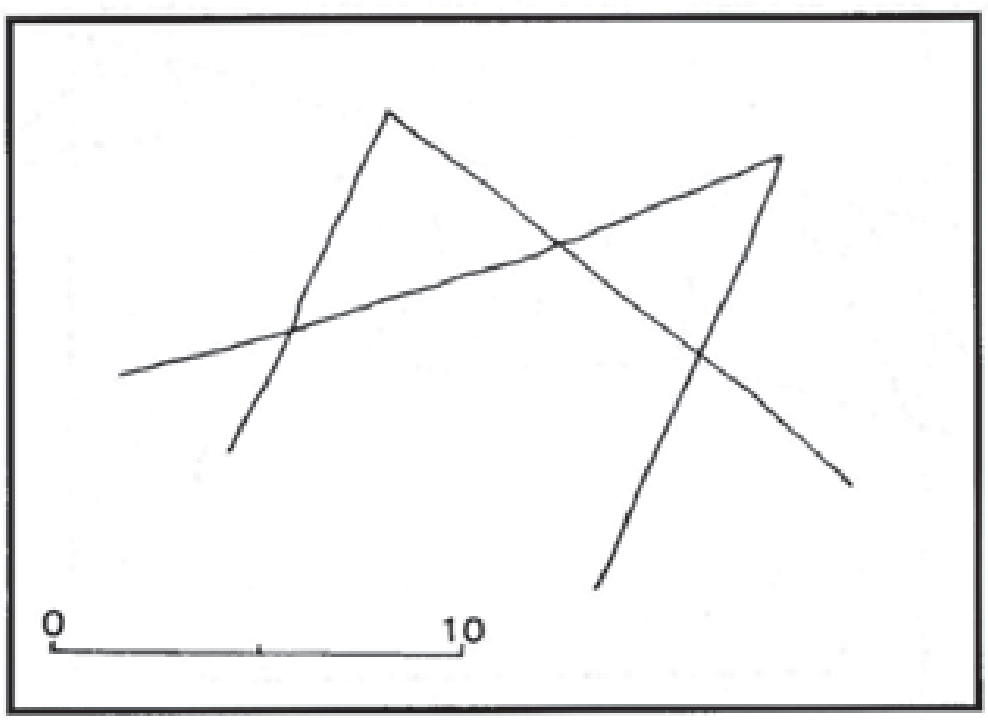

Figura 26. Estrella. 


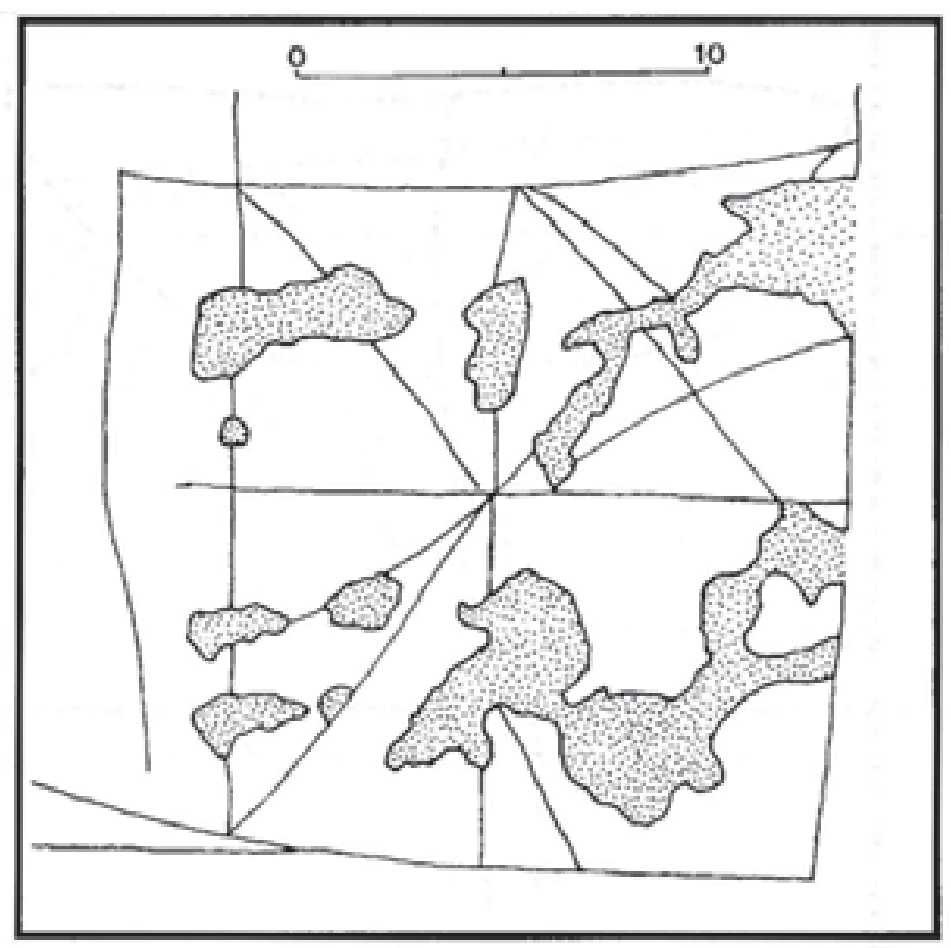

Figura 27. Motivo geométrica.

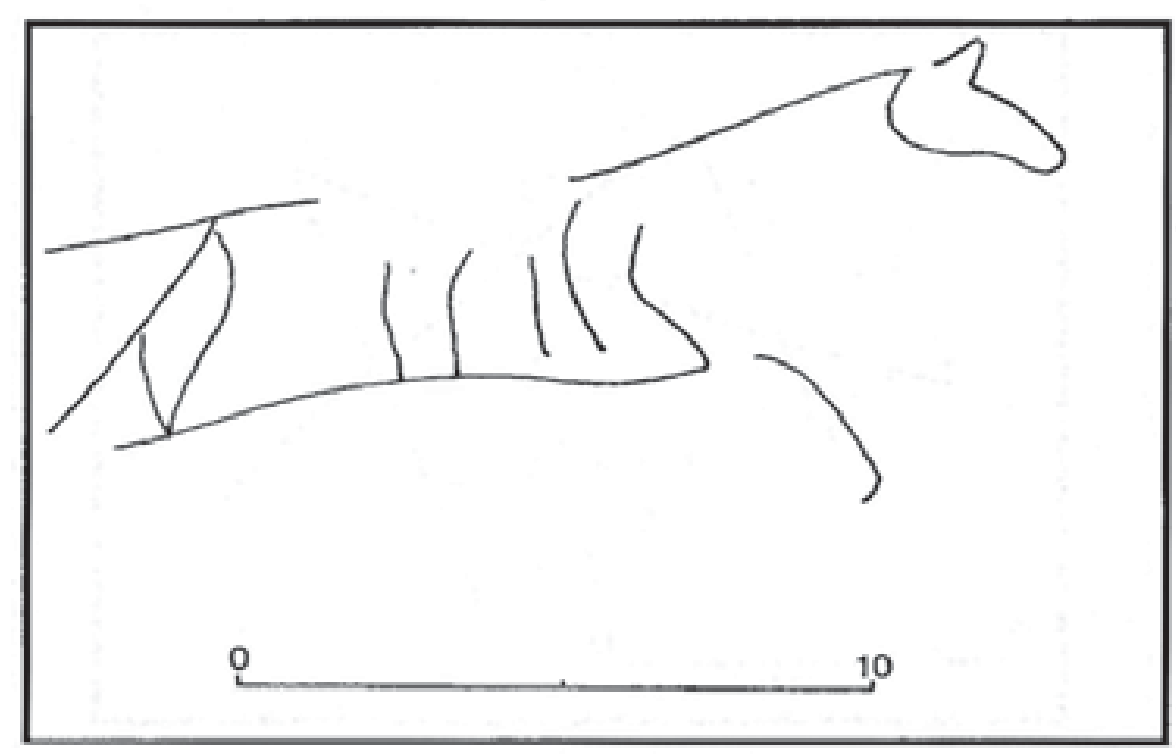

Figura 28. Caballo. 


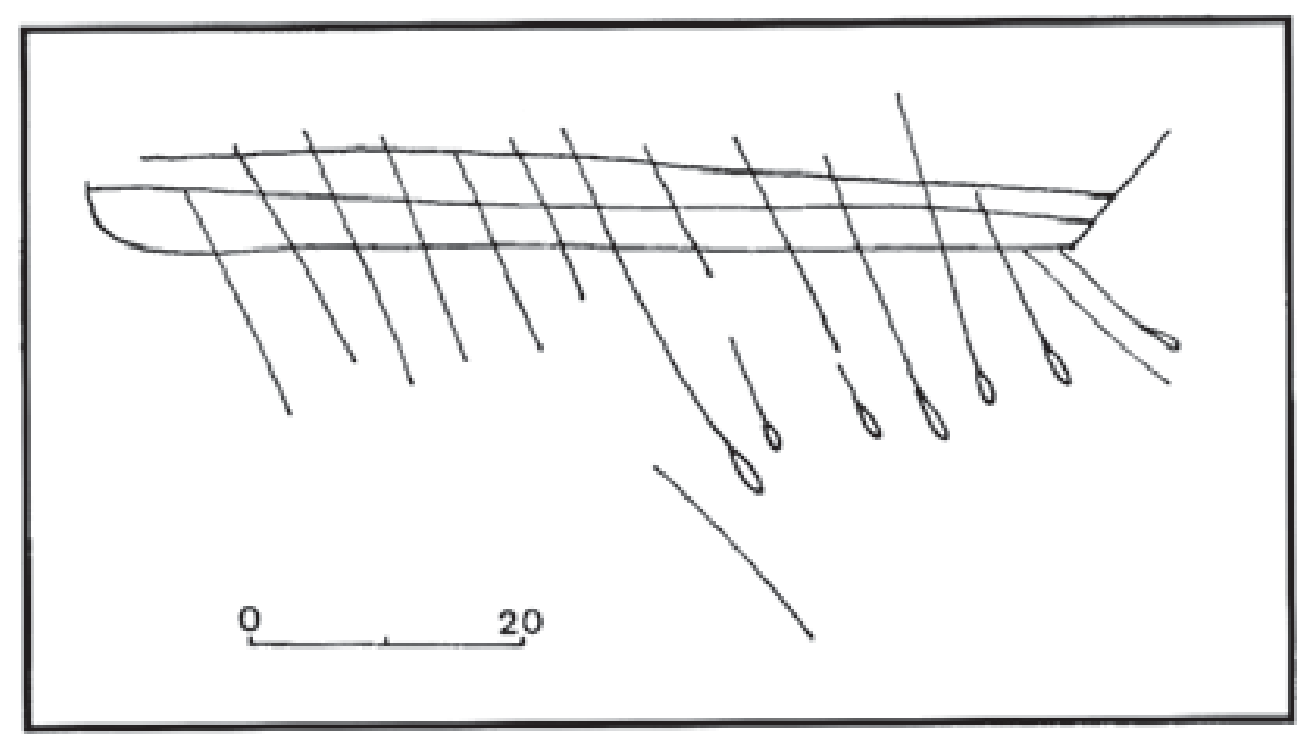

Figura 29. Motvo navel: Posibie curobo (qarb)

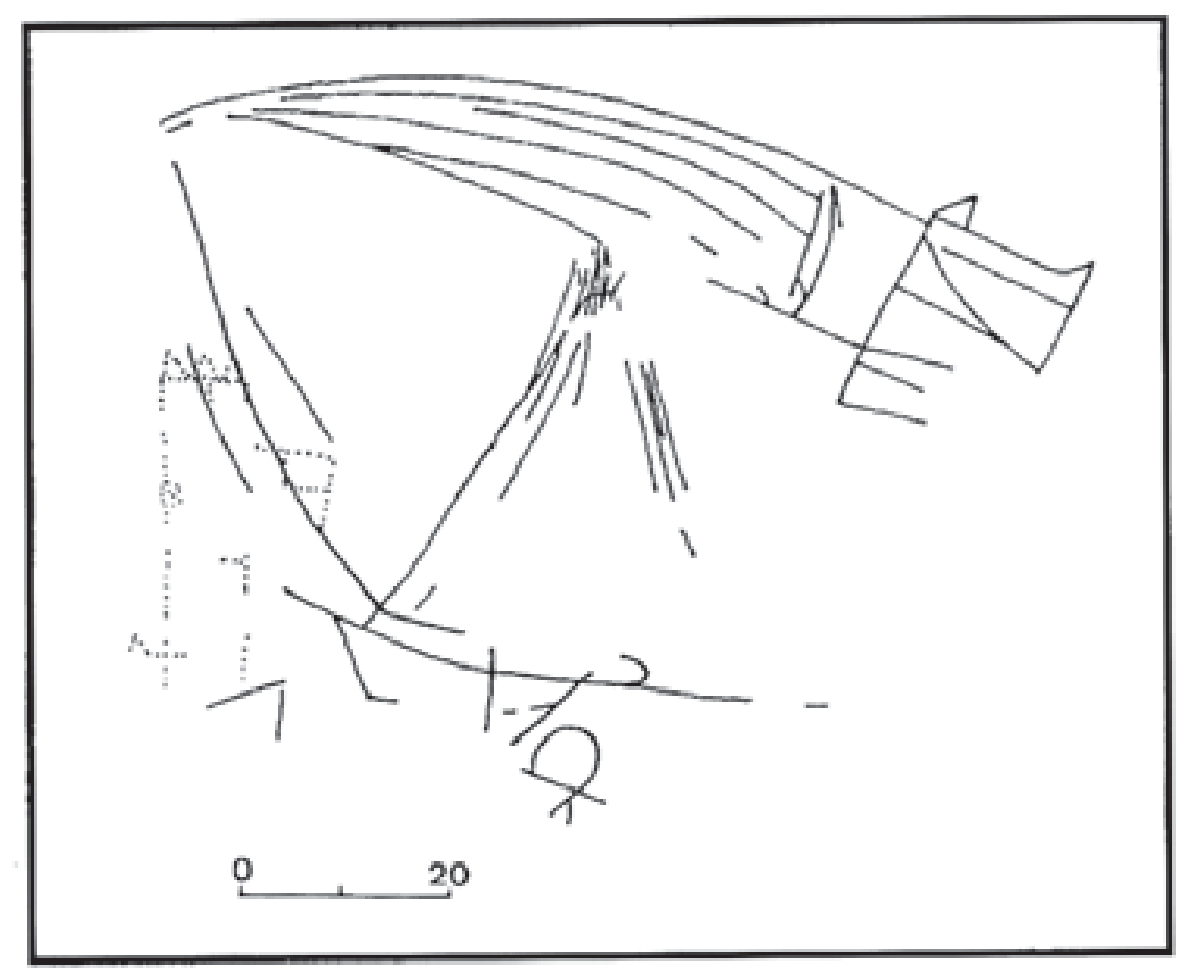

Figura 30 Motwo naval: Árboladira y velamen de una embarcoción. 


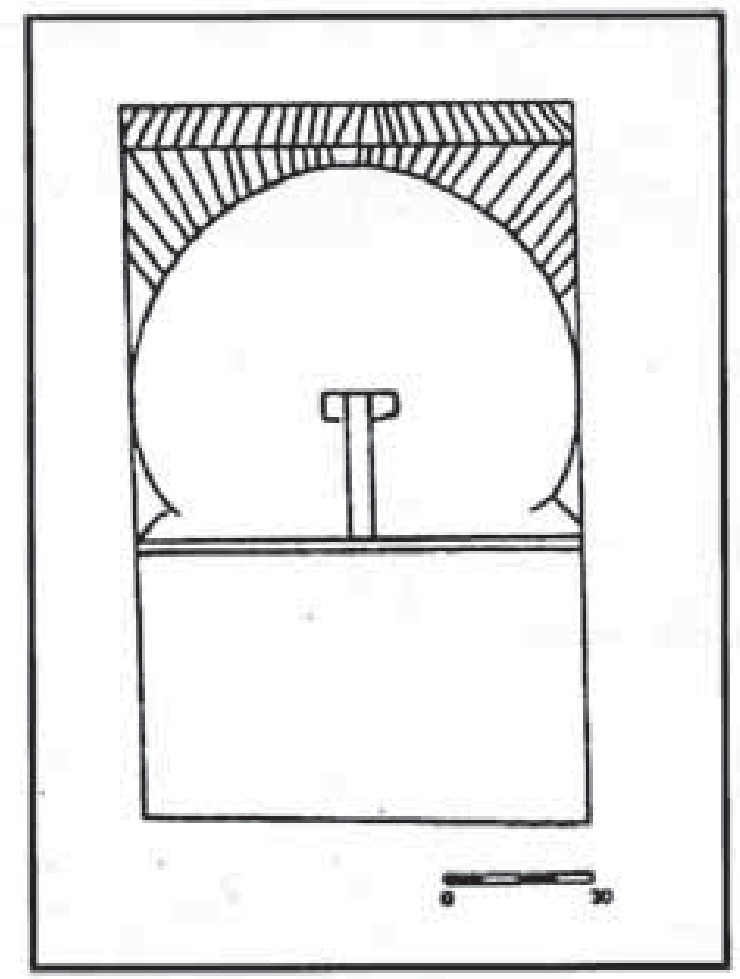

Figura 31. Arco con "escantillón" (Dibujo del articulo de Ruiz y Podial, 2001).

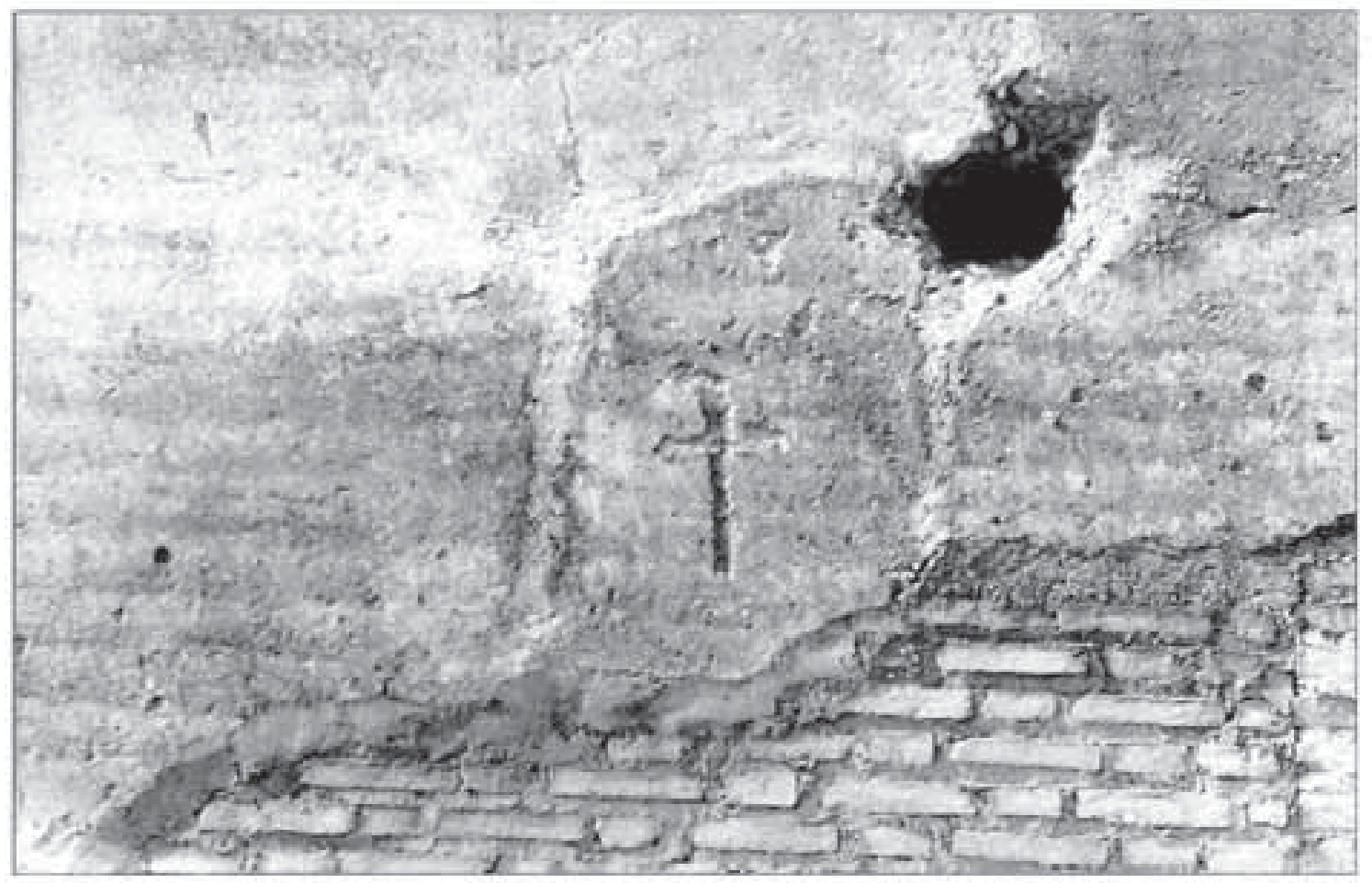

Lómina I. Cnż latina. 


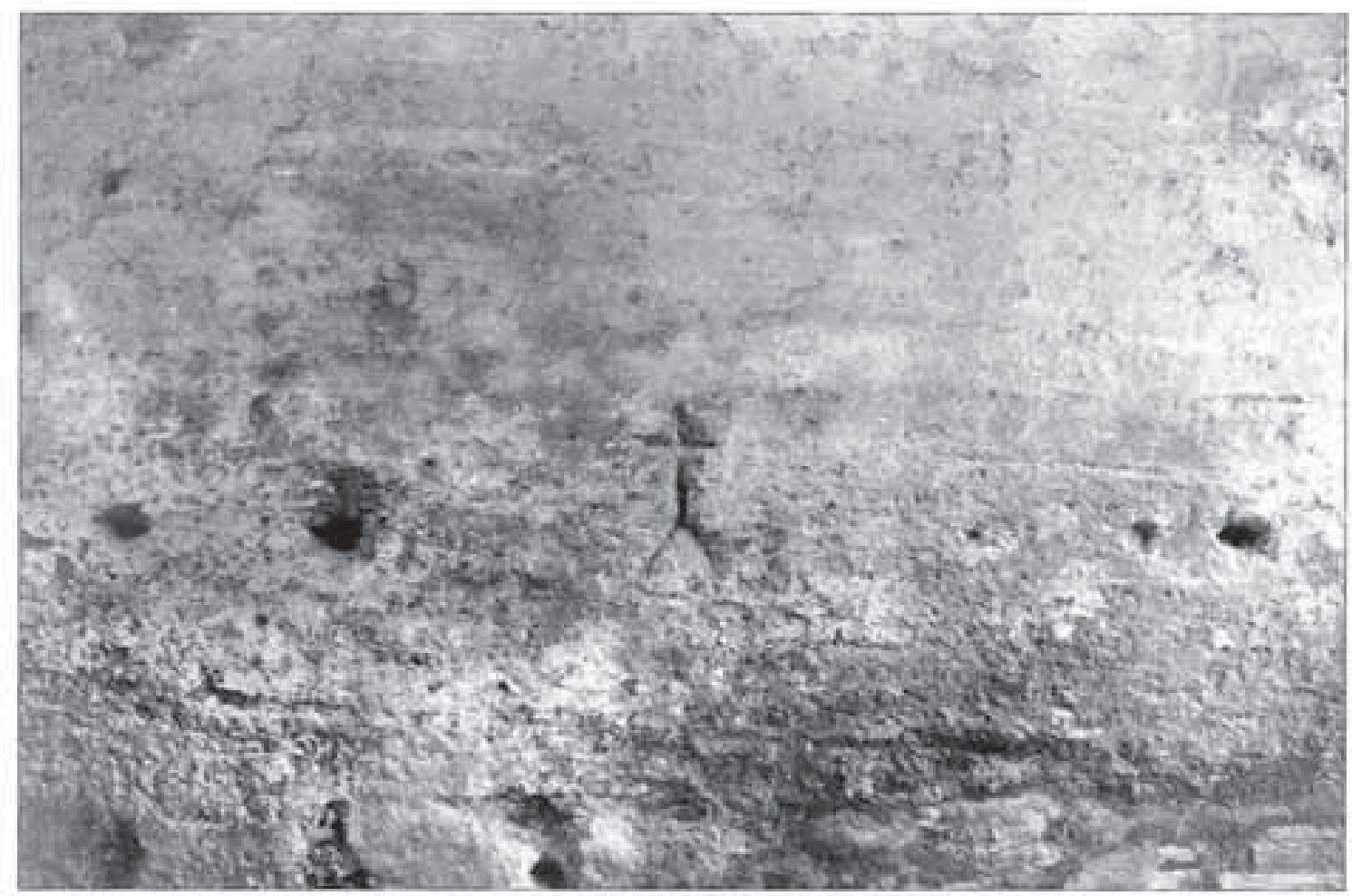

Lámina 2. Cruz sobre aingulo (interior de la Puerto de Fojalauza).

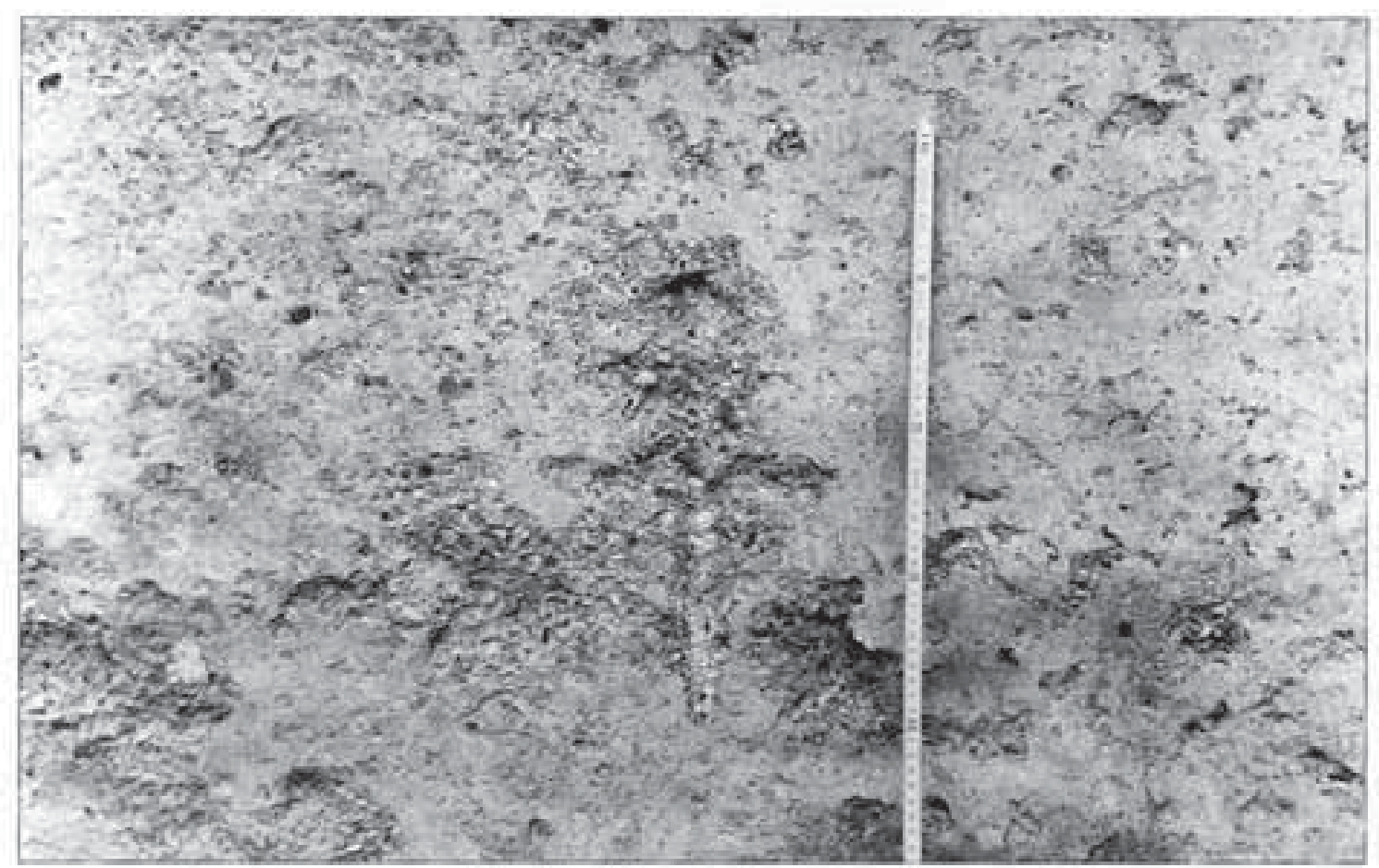

Lámina 3 Gruz papal o patriorcal. 


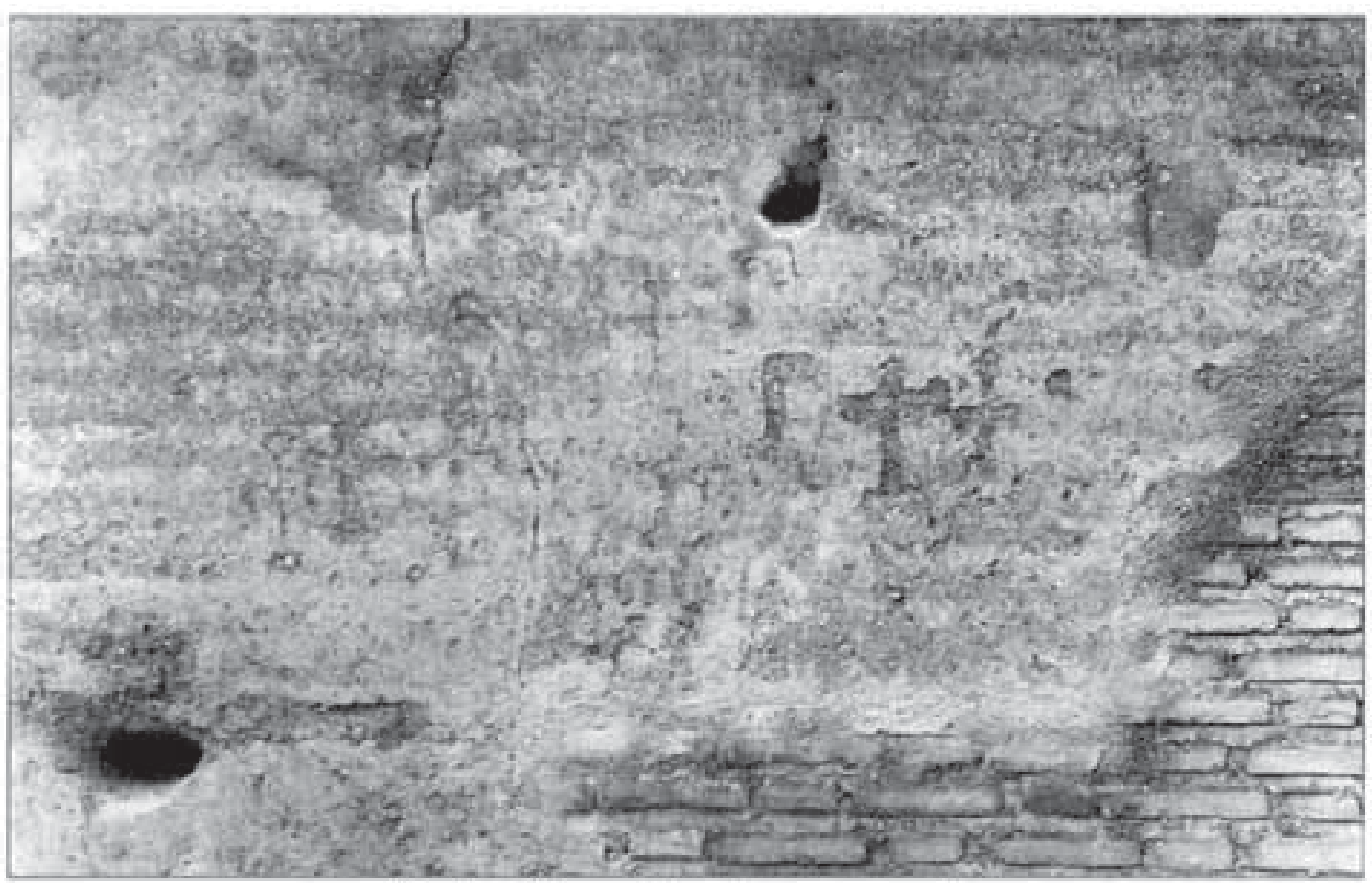

Lámina 4. Cruces latinas, algunas potenzadas.

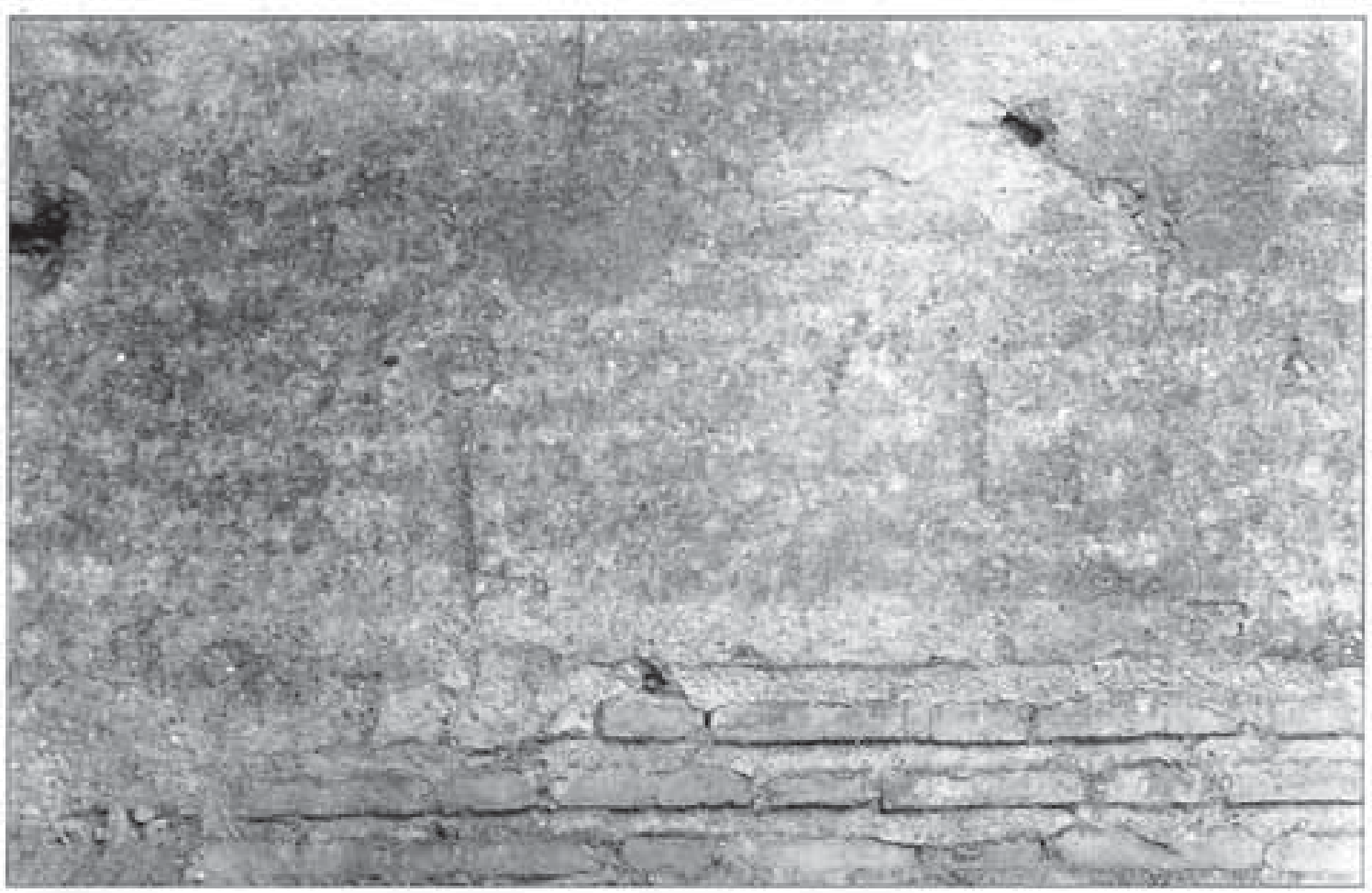

Lámina S. Love 


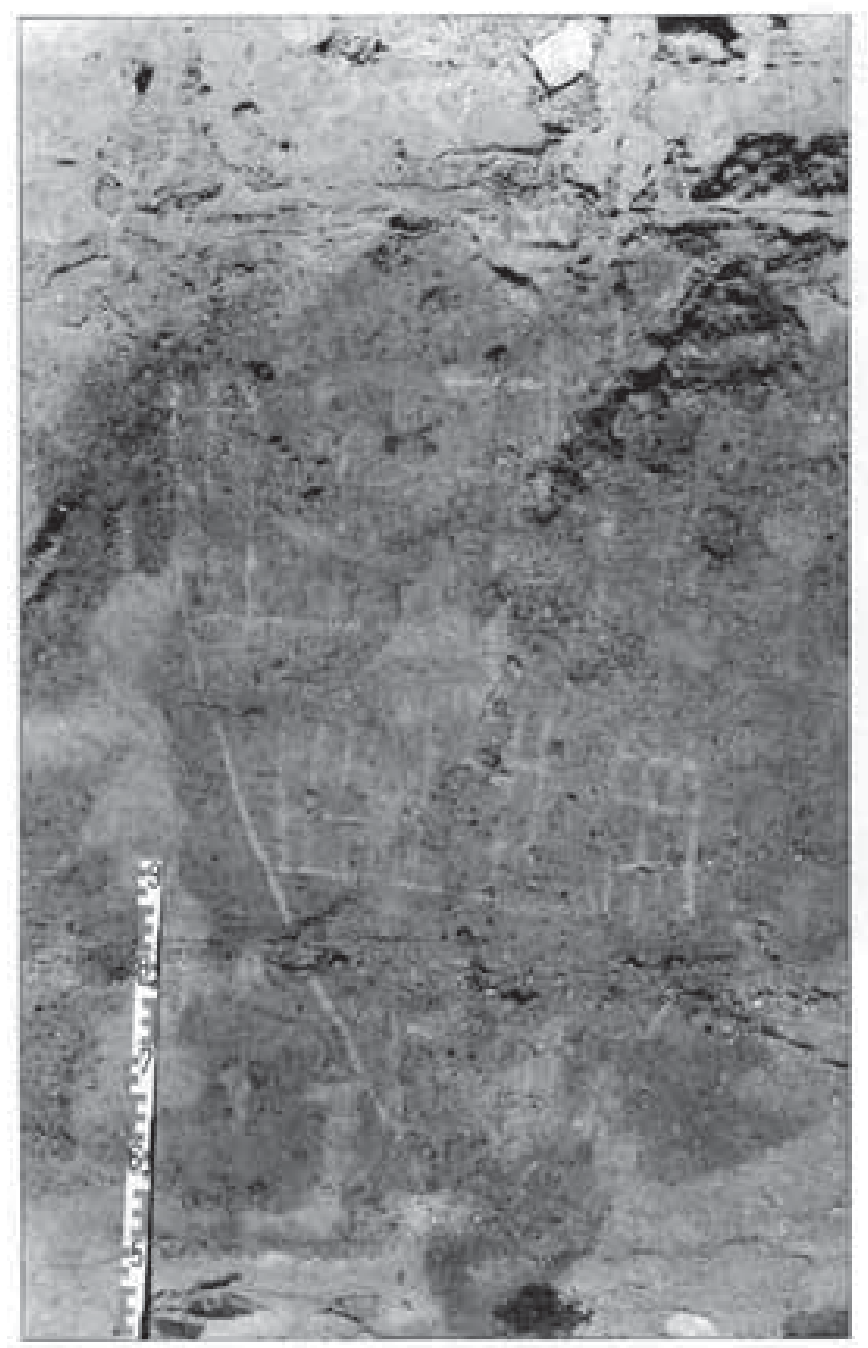

Lámina 6. Costillo $n^{71} 3$ : Escudo

con castilios.

Lámina 7. Castillo n $n^{6}$ : Recinto fortificodo

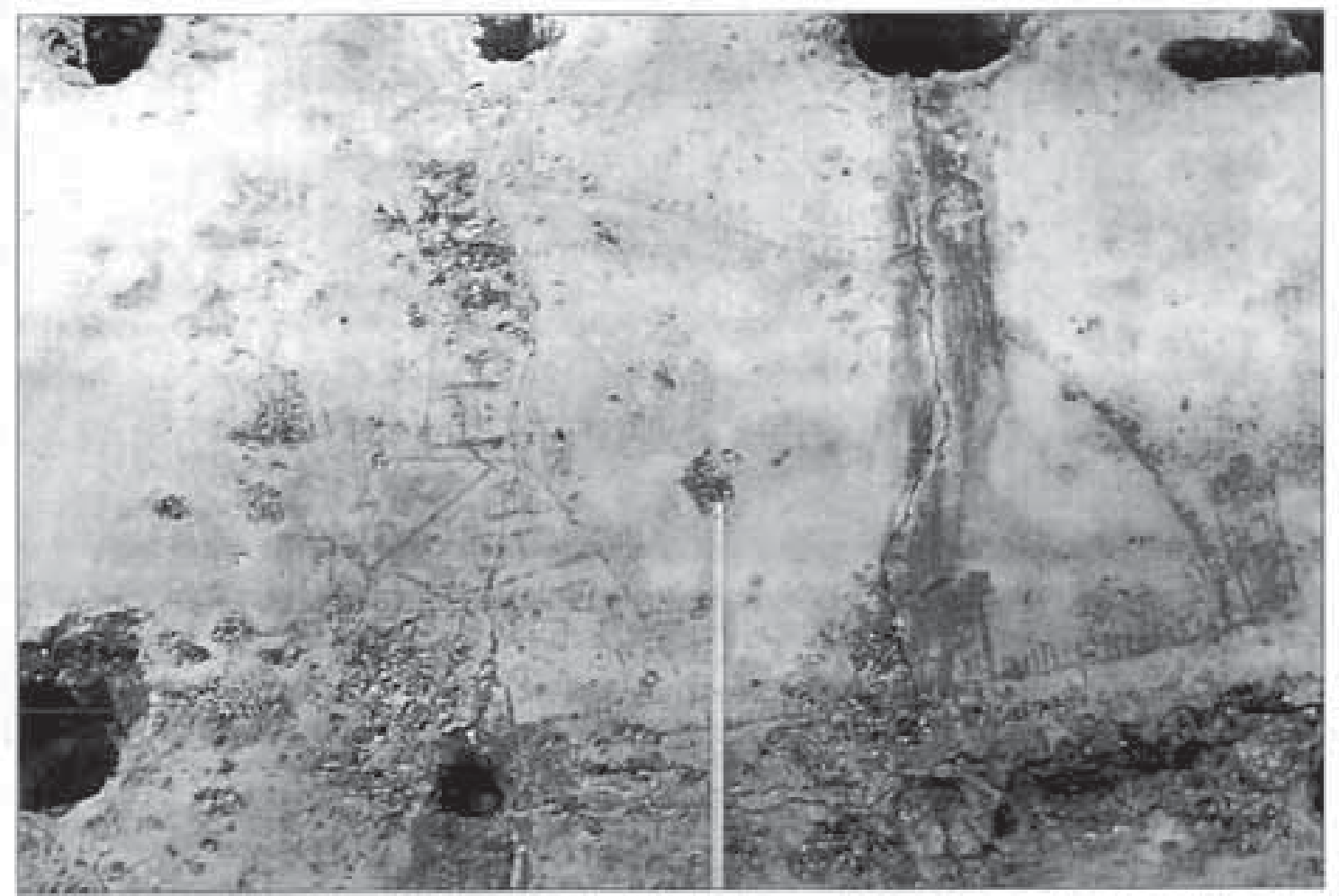




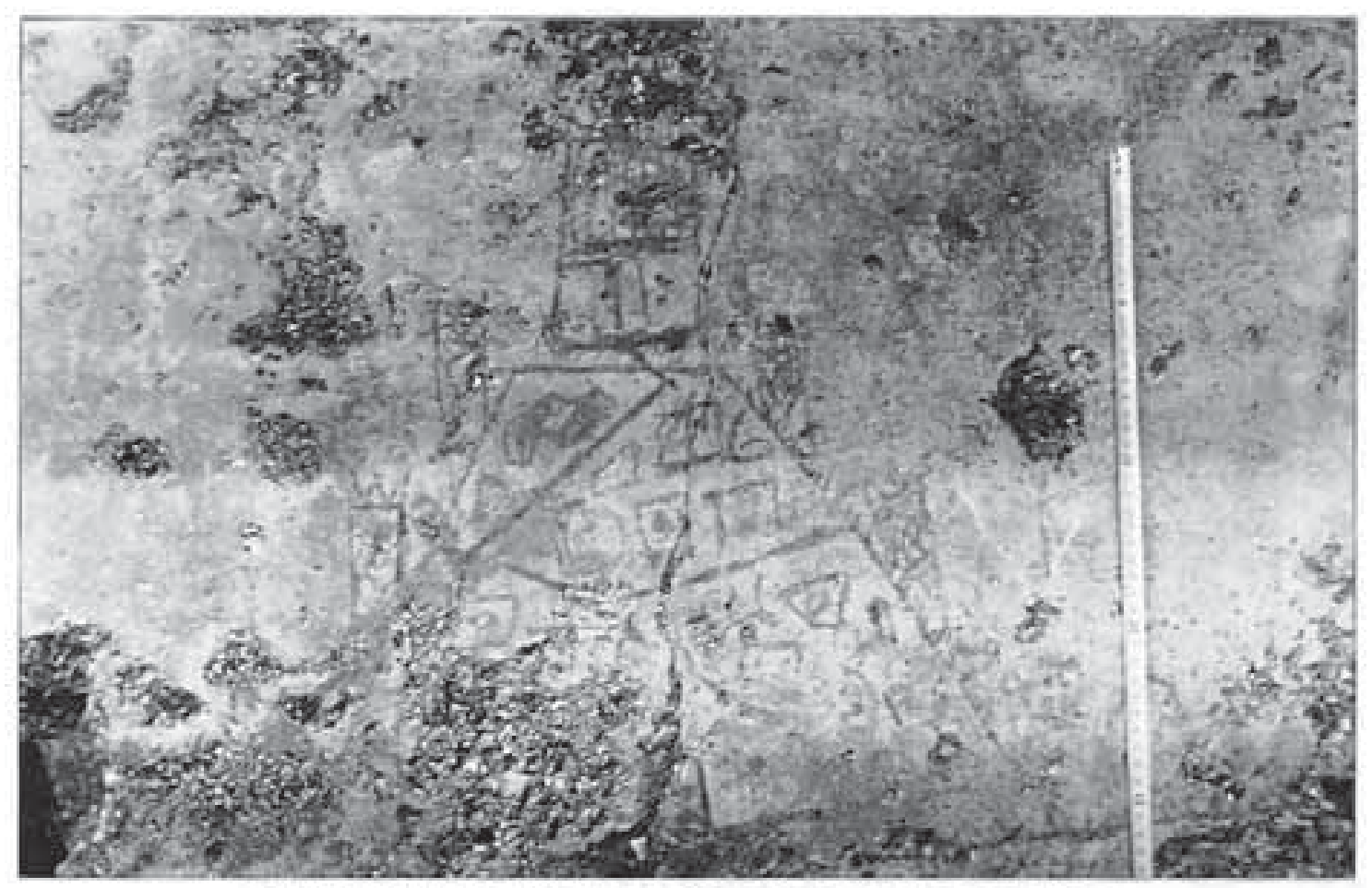

Lámina 8. Detalle del Costilla n" 5 : Tome prinapal tomes seandanos en las laderas y caminos entre el cosería.

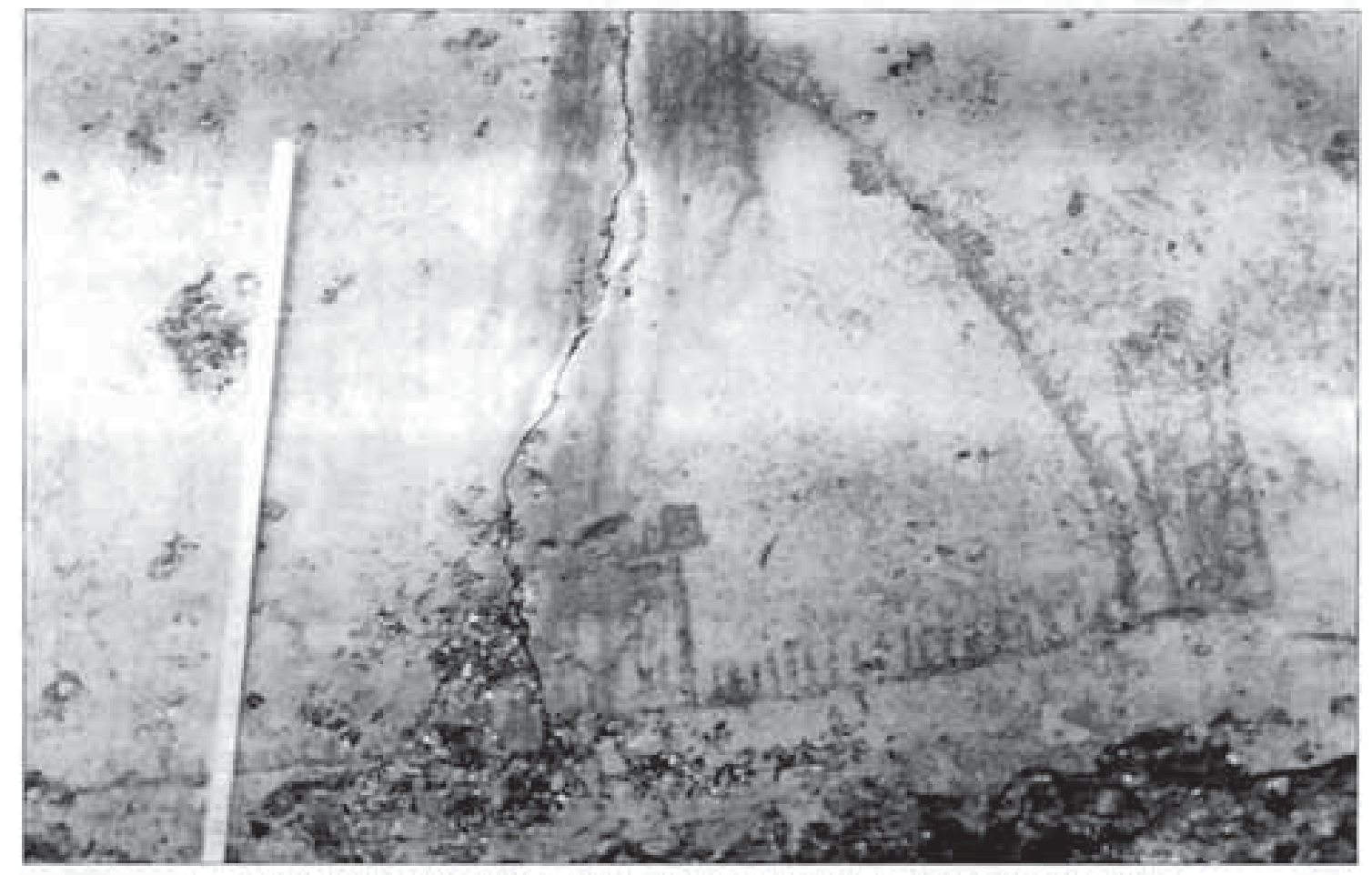

Lámina 9. Detalle del Castilio $n^{\circ} 5$ : Torre con matocán y posible tarre abarrana. 


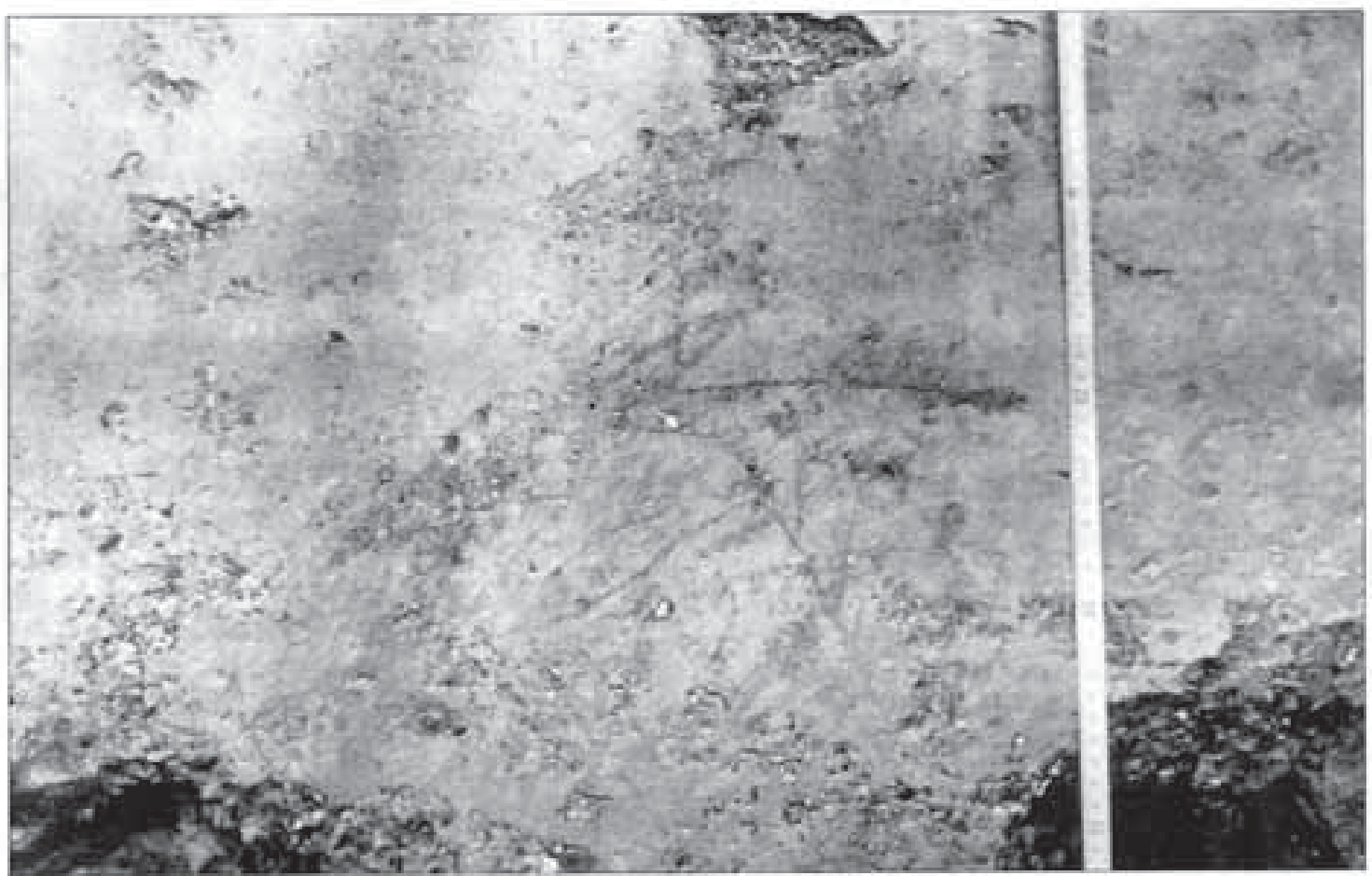

Lámina 10. Boceto borrodo def Castillo n" 5.

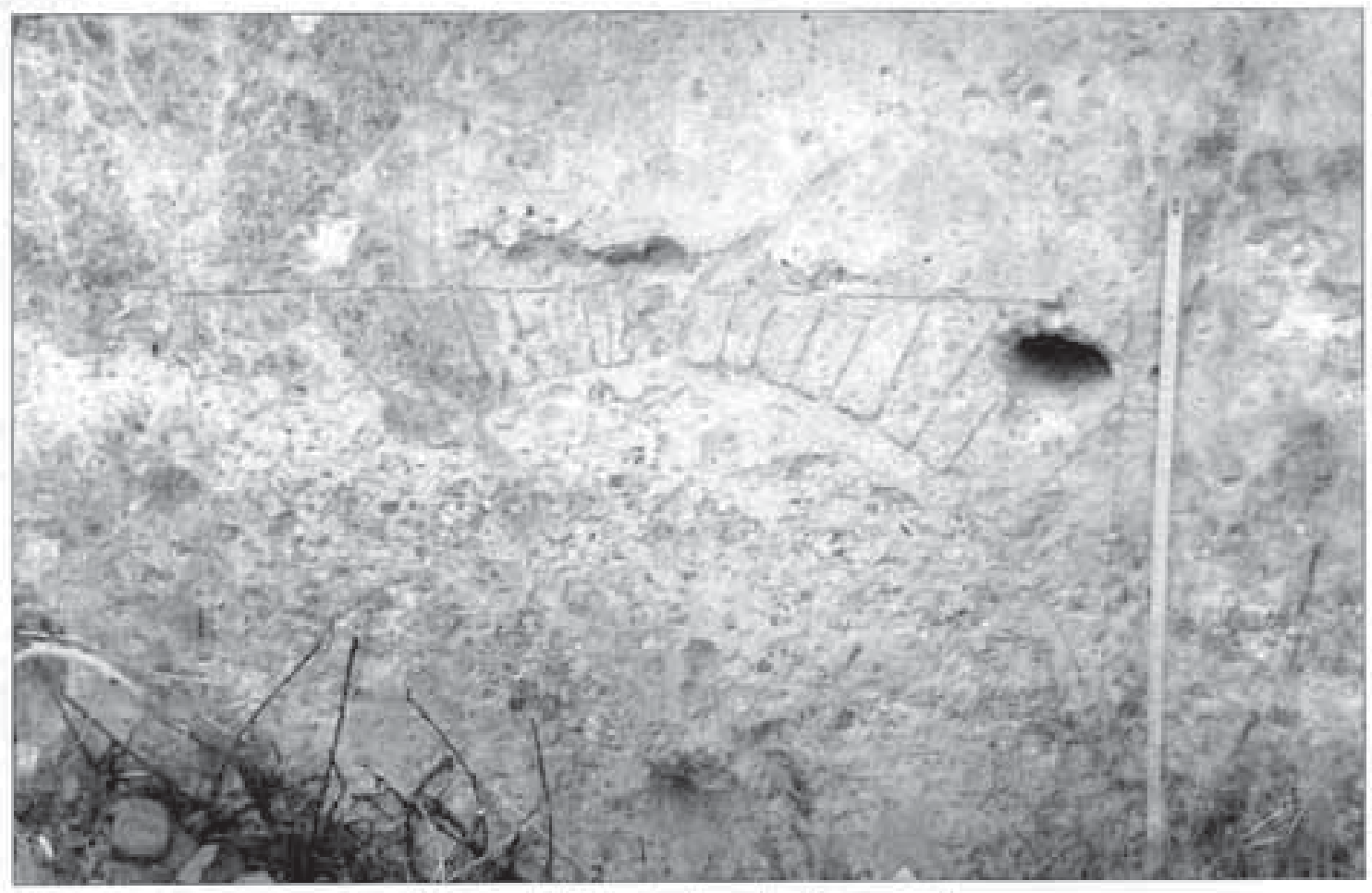

Lómina II. Arço de heradura (ver nota b). 


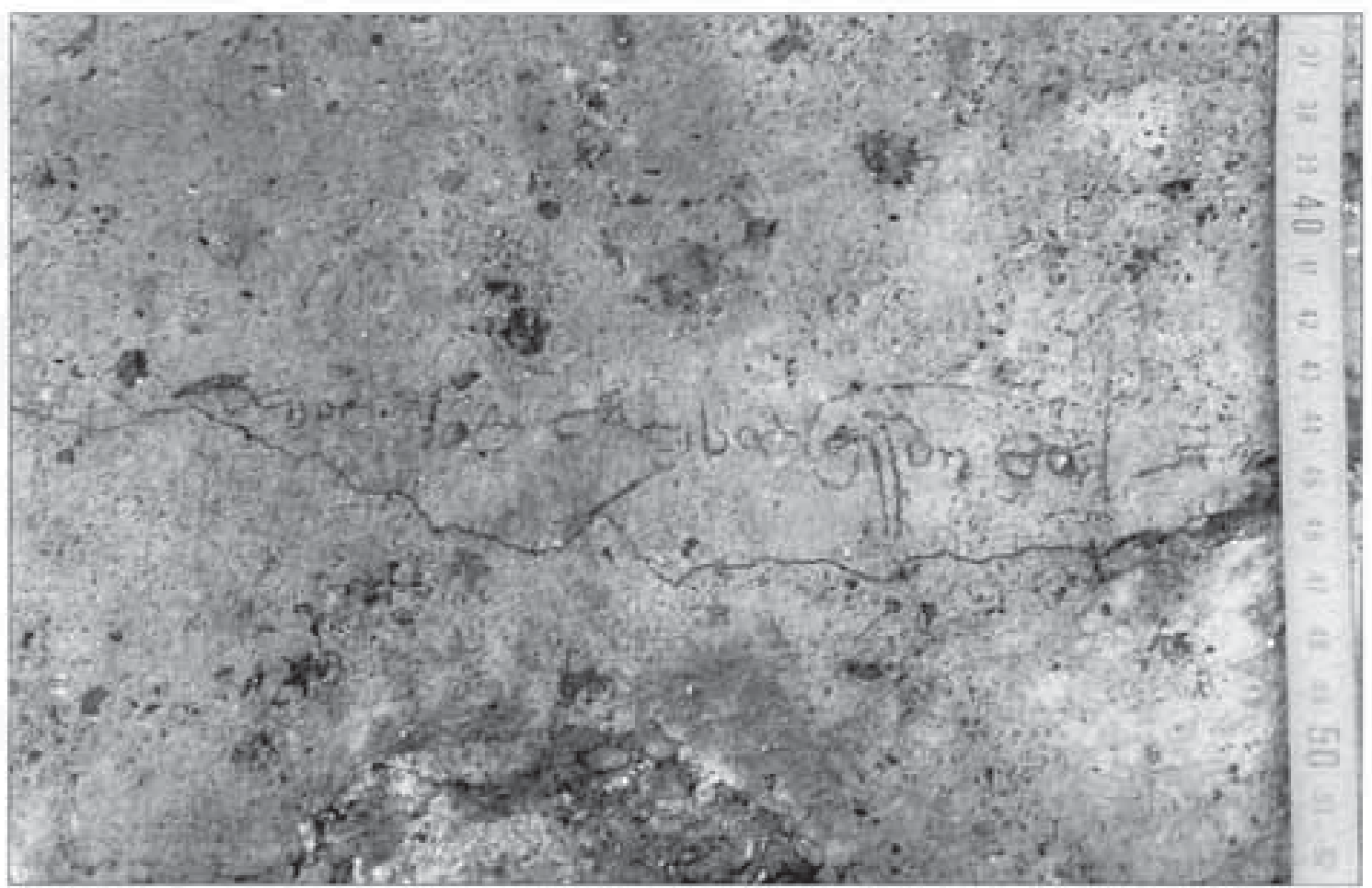

Lámina 12. Inscripoión $9^{2}$ "de nos los catybos q son del Rey".

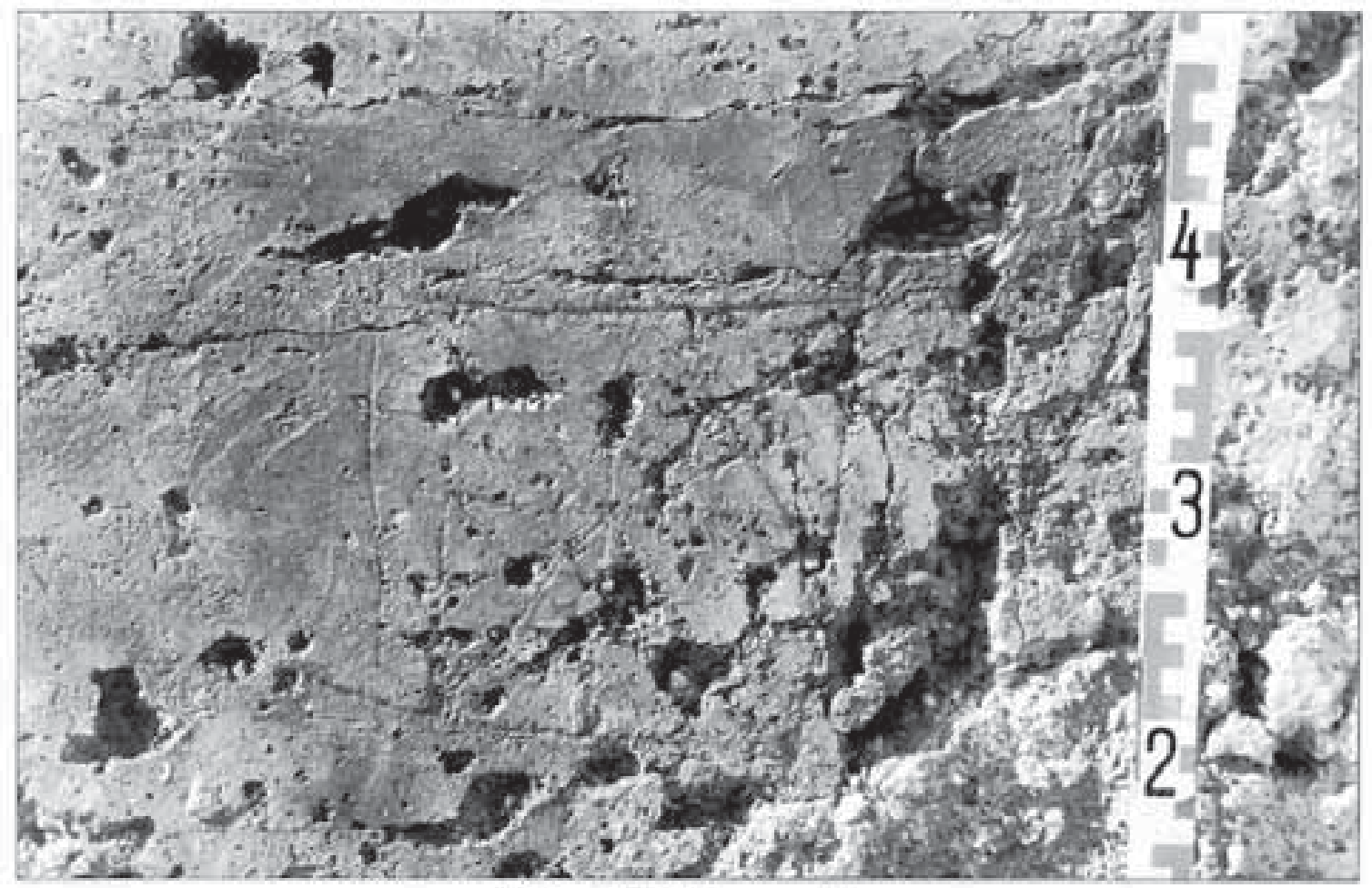

Lámina 13. Notivo geamétrico. 


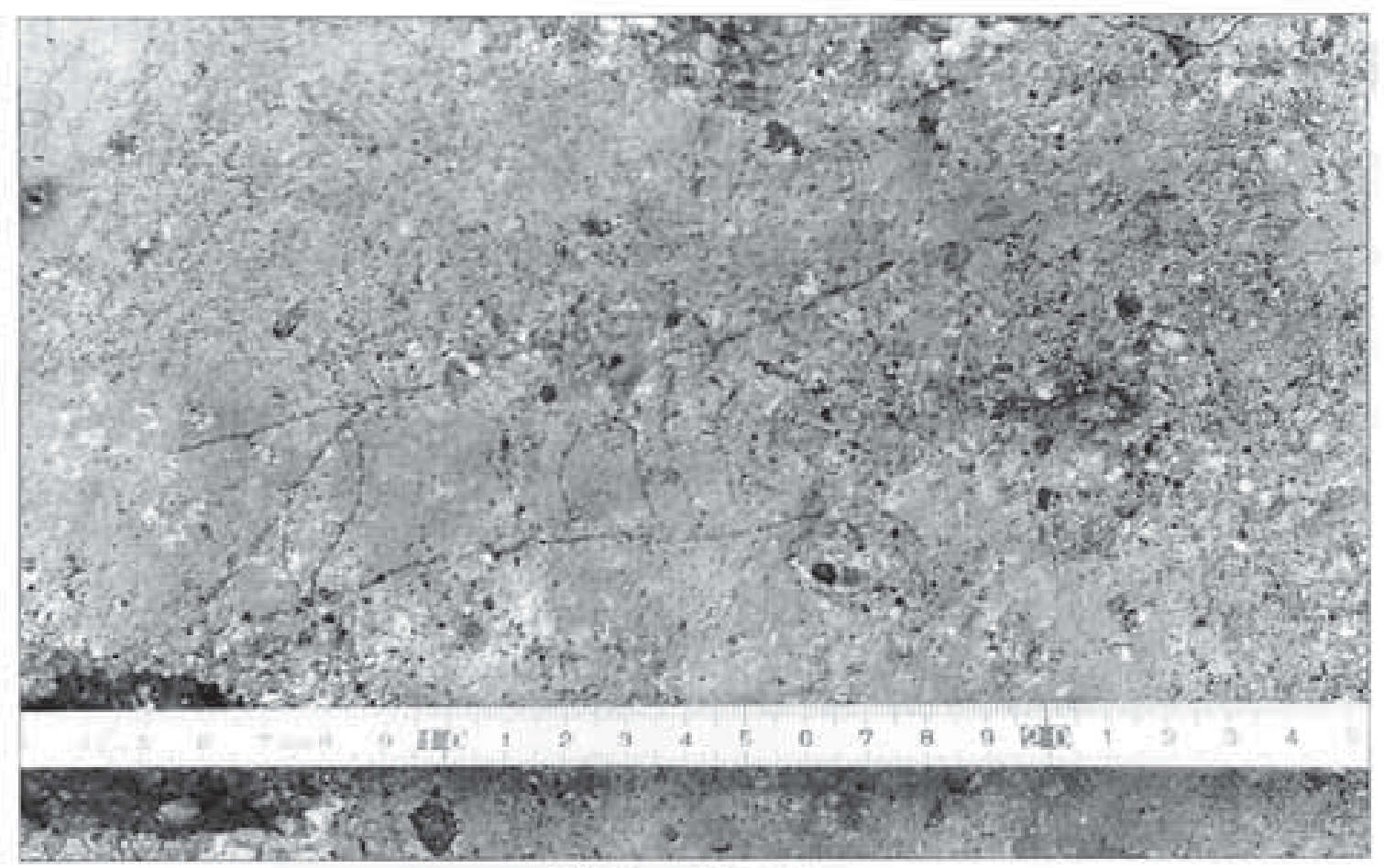

Lámina 14. Caballa. 